University of Rhode Island

DigitalCommons@URI

Open Access Dissertations

1994

\title{
Altruism in College Volunteers: Relationships to Prosocial Personality, Constructive Thinking, and Parenting Variables
}

Sara S. Little

University of Rhode Island

Follow this and additional works at: https://digitalcommons.uri.edu/oa_diss

\section{Recommended Citation}

Little, Sara S., "Altruism in College Volunteers: Relationships to Prosocial Personality, Constructive Thinking, and Parenting Variables" (1994). Open Access Dissertations. Paper 994.

https://digitalcommons.uri.edu/oa_diss/994

This Dissertation is brought to you for free and open access by DigitalCommons@URI. It has been accepted for inclusion in Open Access Dissertations by an authorized administrator of DigitalCommons@URI. For more information, please contact digitalcommons-group@uri.edu. 
$-2=637$

ALTRUISM IN COLLEGE VOLUNTEERS: RELATIONSHIPS TO PROSOCIAL PERSONALITY, CONSTRUCTIVE THINKING, AND PARENTING VARIABLES BY

SARA S. LITTLE

A DISSERTATION SUBMITTED IN PARTIAL FULFILLMENT OF THE REQUIREMENTS FOR THE DEGREE OF DOCTOR OF PHILOSOPHY

IN

PSYCHOLOGY

UNIVERSITY OF RHODE ISLAND

$$
3-3680=1
$$




\section{Abstract}

Altruism--acting with the goal of benefiting another, despite costs to oneself--has been the subject of many studies, yet its underlying mechanisms remain unclear. Laboratory studies have relied on isolated instances of contrived helpfulness, while investigations of actual rescuers and humanitarians are typically small and lack controls. Some investigators have suggested that altruism is merely a function of situation (c.f., Latane \& Darley, 1968). Others, however, have found robust relationships between altruism and personality (c.f., Batson, 1991).

This study investigated sustained, planned altruism in a sample of 469 undergraduates from four major New England Universities. The hypotheses were that altruism, operationalized as consistent volunteer work for altruistic organizations, would be related to personality variables of empathy and responsibility, to moral reasoning style, to constructive thinking under stress, and to retrospective reports of parenting practices that emphasize warm yet firm parental involvement. Measures were self-report questionnaires; precautions were taken to ensure the veracity of self-reported volunteerism.

One-hundred and twenty-four subjects who volunteer for altruistic organizations three or more hours per week and 73 subjects who similarly volunteer 1-2 hours per week, were compared with 173 nonvolunteers who were members of nonaltruistic organizations in a 2-way (Volunteer Work x University) MANCOVA with gender as a covariate. Results support the hypotheses relating prosocial personality and moral reasoning style with altruism. Altruistic 
volunteers reported higher levels of empathic concern, personal responsibility, and practical moral reasoning than did nonvolunteers. Results did not support the hypothesized relationship between parenting practices and altruism. Only one aspect of parenting, parental involvement/acceptance, was significantly related to volunteer work: altruistic volunteers recalled less parental involvement/acceptance than did nonvolunteers. It is important to note, however, that subjects were asked about parenting practices employed during their adolescence rather than during their childhood. Two additional variables, high-school volunteerism and informal helpfulness, were also related to volunteer work.

Overall, differences between altruistic volunteers and nonvolunteers-particularly between nonvolunteers and altruists who volunteer three or more hours per week--accounted for about $19 \%$ of the variance between groups. Differences among male and female altruists were noted, and warrant further investigation. 


\section{Acknowledgment}

Without the selfless contributions of my family and friends, this study of altruism would never have materialized. There are no words to express my gratitude to my husband, who delayed his own career advancement to serve as breadwinner, housekeeper, single parent, and source of moral support, while I pursued an out-of-state doctoral program. There is, similarly, no way to sufficiently thank my children, Alexander and Alicia, who made room for this project in their lives as if it were a sibling.

I also thank my parents, Hannah and Morris Goldkorn, for the unfailing support they gave to me, my husband, and our children, even though they couldn't imagine why a woman with a family and career would also want a Ph.D. Thanks also go to my sister, Dr. Helen Lichtman, and my brother-in-law, Dr. Jeffrey Lichtman, who tried to explain it to them.

To Dr. Sue Allen Warren, I give separate thanks for each of the many roles she played through the years, any one of which would have sufficed: as a friend, she was always there when needed; as a mentor, she demanded my personal best while accepting my limitations; as a role model, she was an inspiration; and as my mother-in-law, and my children's grandmother, she is incomparable.

In addition to family, numerous friends, colleagues, and faculty contributed to this research by sharing their time, slipping journal articles into my mailbox, 
helping me carry heavy boxes of data, deciphering computer error messages, etc. There is no room on this page to name everyone, but I thank you all. My committee members deserve extra thanks for all their efforts on my behalf. Janet Kulberg, my major professor, has been supportive from the beginning, spending countless hours listening and critiquing ideas, hypotheses, and, at along last, results. Charles Collyer's analytic skills were most appreciated as my design grew from a one-way MANOVA to a factorial design with covariates, interactions, and stepdown analyses. Lynn McKinney, Director of Campus Compact, helped open doors, so that I could accomplish this ambitious undertaking at four universities. Diane Horm-Wingerd lent her ear, and her early-childhood expertise. Al Lott was always willing to answer questions--in the classroom, in the mailroom, in the hallway or even in line at the photocopier.

I also would like to thank Anne Colby, Director of the Murray Research Center, who took my interest seriously from the very beginning and altruistically shared her time and suggestions.

Last but not least, special thanks go to the directors and members of campus organizations and student activities across the four universities. Without them, there would be no results. 


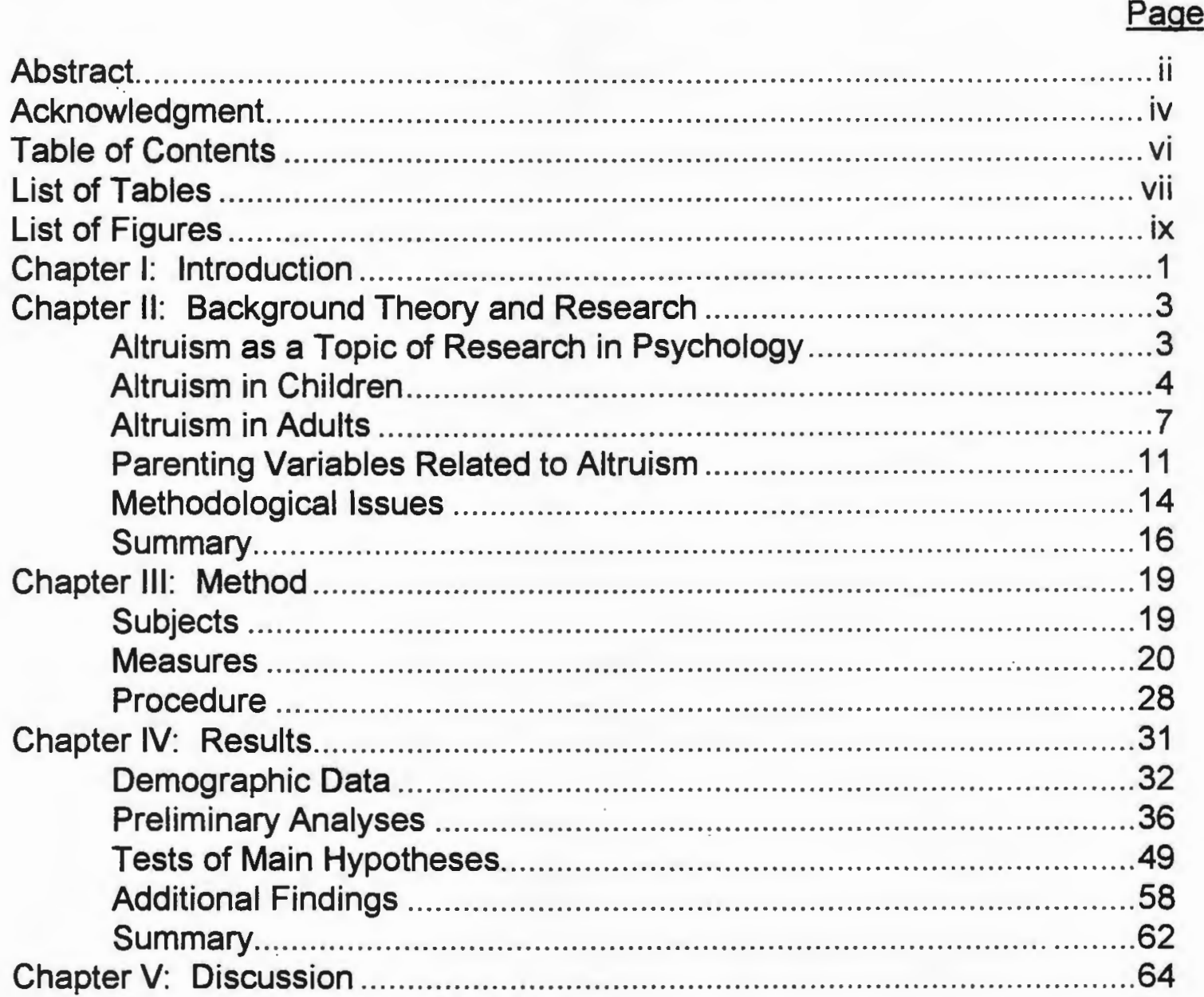

Prosocial Personality Variables:

Empathy, Personal Responsibility and Moral Reasoning.............64

Constructive Thinking ................................................................69

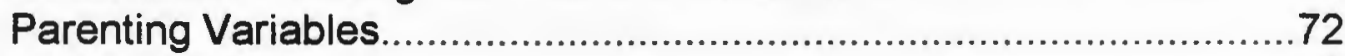

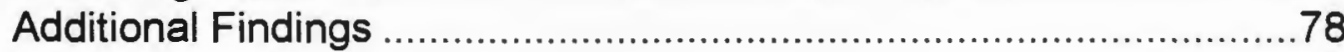

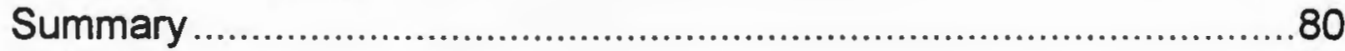

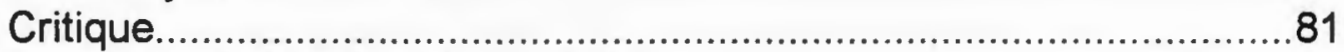

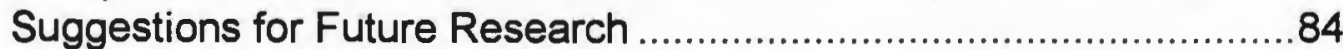

Implications for School Psychology Practice...................................86

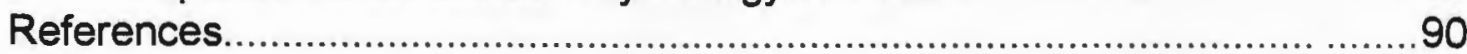

Appendix A. Informed Consent Statement ...............................................97

Appendix B. School and Home Experiences Survey ...................................98

Appendix C. Notices to Students (soliciting participation) .........................111

Appendix D. Descriptions of the Four Participating Universities ...............114

Appendix E. Additional Tables and Data ..............................................115

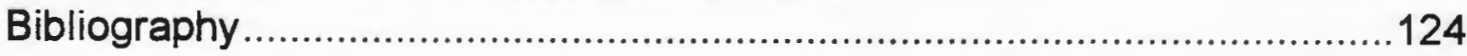




\section{List of Tables}

Table

Page

1. Breakdown of Subjects by Volunteer Status, University, and Gender ...... 19

2. Demographic Data With and Without Targeted Altruistic Volunteers....... 34

3. $\underline{x}^{2}$ Comparisons of Demographic Variables Across 4 Universities 39

4. $\underline{X}^{2}$ Comparison of Demographic Variables Across 5 Levels of Volunteer Work

5. Correlations Among Volunteer Work, Personality, Parenting, and Behavioral Variables for 469 Subjects

6. Summary Table of MANOVA for Organization and University on 11 Personality, Parenting, and Behavioral Variables, for Nonaltruists $(\underline{\mathrm{N}}=252)$.

7. Summary Table of MANOVA for Gender, Volunteer Work, and University on 11 Personality, Parenting, and Behavioral Variables $(\underline{N}=369)$

8. Summary Table of MANCOVA for Volunteer Work and University, for 11 Variables, with Gender as Covariate $(\underline{N}=369)$

9. Univariate and Stepdown F-tests for Effect of Volunteer Work ( 3 levels) on 11 Variables, with Gender as a Covariate $(N=369)$

10. Multivariate Follow-up Contrasts for Significant Main Effect of Volunteer Work on 11 Variables, with Gender as a Covariate

11. Univariate F-tests for Follow-up Contrasts: Effect of Volunteer Work on 11 Variables with $(1,356) \mathrm{df}$, with Gender as a Covariate

12. Significant Differences Among Means for 11 Personality, Parenting, and Behavioral Variables Across 3 Levels of Volunteer Work $(\underline{N}=369)$, Adjusted for Gender

13. Roy-Bargmann Stepdown $\mathrm{E}$ tests for Follow-up Contrast \#2: Volunteers of $3+\mathrm{Hrs}$. Mk. vs. Nonvolunteers, with Gender as a Covariate

14. Follow-up Univariate F-tests for Effect of Volunteer Work (2 levels) on 11 Variables for 228 Women and for 141 Men

15. MANOVA for Organization Membership for Nonvolunteers for 11 Variables

16. Means and Standard Deviations for 11 Variables by Gender.

17. Univariate E-tests with $(1,356)$ df for Regression of Gender on 11 Variables $(\underline{\mathbf{N}}=369)$ 
18. Pooled Within Cells Correlations for 11 Variables, Adjusted for Gender, with Standard Deviations on the Diagonal $(N=369)$

19. Combined Means for 11 Variables Across 2 Levels of Volunteer Work, by Gender ( 141 Men, 228 Women).

20. Combined Means for 11 Variables Across 4 Levels of University, by Gender ( 141 Men, 228 Women). 


\section{List of Figures}

Figure

Page

1. Interaction of Organization Membership and University on Parental Involvement/Acceptance for Non-Altruists ( $N=252$ ) 


\section{Chapter I}

Introduction

Altruism--acting with the goal of benefiting another, despite costs to oneself--has been the subject of many studies in the past 20 years (Piliavin \& Charng, 1990). Several investigators have identified one or more personality variables that appear to be related to altruistic behavior. The most robust of these variables are empathy, ascription of responsibility to oneself, and internalized moral values of justice and care. In addition, a sense of one's own competence and a positive approach to life's problems have been related to altruism by some investigators.

A related body of research describes the influence of parenting practices on prosocial behaviors. Prosocial behaviors are defined by Eisenberg and Mussen (1989) as "...voluntary actions that are intended to help or benefit another individual or group of individuals..." (p.3), regardless of motivation. The literature in this area indicates that parents' warm, firm, democratic disciplinary practices and parents' capacity for empathy may be related to prosocial behaviors such as cooperation and sharing in childhood and later adulthood.

The relationship between prosocial behavior and altruism is described by Eisenberg and Mussen (1989) as one of degree. Altruism may be considered a specific type of prosocial behavior that is motivated by internal motives such as concern or sympathy, or by values and self-rewards, rather than by personal 
gain. Piliavan and Charng (1990) point out that, for many investigators, a key factor in altruism is the presence of substantial cost to the altruist.

This study is an investigation of the relationship of prosocial personality variables, constructive thinking, and parenting practices, with altruism in a college population. It addresses the question of whether altruism--defined as unpaid volunteer work--is related to personality variables of empathy and responsibility, to moral reasoning style, to constructive thinking, and to parenting practices that emphasize warm yet firm parental involvement. 
Chapter II

Background Theory and Research

\section{Altruism as a Topic of Research in Psychology}

Although altruism has been a topic of research in psychology for over 30 years, studies published prior to 1980 focused primarily on situational determinants of altruism (c.f., Epstein, 1979, 1980; Krebs \& Miller, 1985). These studies typically found significant correlations between altruistic behavior, such as bystander rescue, and situational variables, such as amount of time available or number of potential helpers present (e.g., Darley \& Batson, 1973; Latane \& Darley, 1968).

The "zeitgeist" of research on situational determinants, rather than on personality characteristics of altruists, may perhaps be traced back to Hartshorne and May's (1928, 1929, 1930) landmark studies of morality in nearly 2,000 schoolchildren. Hartshorne and May found "...no evidence of any trait of goodness or character...Any community of conduct is due to factors common to the situations represented in the test and not to an inner organization of habit systems or abilities" (1930, p. 173).

Years later, however, researchers began to question the adequacy of Hartshorne and May's methodology and statistical techniques. Burton (1963) reanalyzed a portion of Hartshorne and May's original data using factor analytic techniques and found a principal component of honesty that accounted for $35 \%$ to $42 \%$ of the variance. Rushton $(1976,1984)$ and Epstein $(1979,1980)$ have 
both provided evidence that consistency in altruistic behavior across situations may account for as much as $25 \%$ to $50 \%$ of the variance when multiple measures, rather than individual instances of behavior, are analyzed.

Piliavin and Charng (1990) noted a paradigm shift in research on altruism from situational variables to personality variables in the 1980's. Hoffman's (1979) theory of moral development, in particular, sparked much research on the relationship of emotional and social learning variables to the development of altruism and other prosocial behaviors in children (c.f., Damon, 1988; Eisenberg \& Mussen, 1989; Hoffman, 1988; Zahn-Waxler, Radke-Yarrow, Wagner, \& Chapman, 1992).

\section{Altruism in Children}

Studies of altruism and prosocial behavior in children have investigated a wide array of variables, including empathy, gender, age, perspective-taking ability, self-confidence, modeling, and attributions. Despite this diversity, and the difficulties of developmental investigations, some patterns appear to have emerged.

Empathy, which Hoffman defined as "...an affective response appropriate to someone else's situation rather than one's own" (1981, p.44), has been related to children's expressions of care, concern, and altruism from an early age. Children as young as one to two years have been observed to respond to others' emotional distress with distressed facial expressions, crying, and even attempts to help (Radke-Yarrow \& Zahn-Waxler, 1984; Zahn-Waxler \& Radke-Yarrow, 
1982; Zahn-Waxler et al., 1992). With increasing age, various helping behaviors increase, apparently due to interactions of empathy with other developing characteristics, rather than due to an increase in empathy per se. Chapman, Zahn-Waxler, Cooperman, and lannotti (1987) concluded that "...it may not be merely a tendency to feel the same affects as the other person...that motivates helping, but a disposition to feel a responsibility toward the other person's well-being" (p.145). In a similar vein, Barnett, Howard, Melton, and Dino (1982), found that empathic personality alone was not sufficient to explain helping among sixth graders. Empathy was related to helping only among children who had earlier recounted a story about "... a sad individual other than themselves." Equally empathic children who had recounted an affectively neutral experience, or even a sad personal experience, were less likely to help. The authors surmised that empathic children may need to be alerted to relevant cues in others before they will respond altruistically.

One variable that changes with age, and has been related to altruism in the literature, is competence. Midlarsky and Hannah (1985) and Peterson (1983) have demonstrated that age-related increases in altruism may be due to increased competence and responsibility, and not simply due to maturation. Additional support for this hypothesis comes from a longitudinal study by Block and Block (1973; in Eisenberg \& Mussen, 1989, pp. 63-64), in which the most competent (i.e., "ego-resilient") preschoolers were also the most helpful, cooperative, and considerate classmates, and in which coping ability at age four 
predicted generosity at age five. Midlarsky (1984) has proposed a model for development of helping behavior in which competence plays a key role.

According to this model, a potential explanation for the relationship between perceived competence and helping behavior is the possibility that "...if one views oneself as potent the world is likely to be seen as a relatively nonthreatening place," (p. 292).

Another variable that has often been investigated in relation to prosocial behaviors is moral reasoning. A review by Blasi (1980) concluded that low levels of moral reasoning in children and adolescents predicted delinquency and dishonesty, while higher levels of moral judgment were correlated with helping and generosity. Eisenberg and Mussen (1989) similarly report that "...positive though moderate correlations (between moral reasoning and prosocial behavior) are typical" (p.129).

In summary, research on children's altruism and prosocial behavior suggests a link between empathy, responsibility, confidence in one's problemsolving abilities, and moral reasoning on the one hand, with the development of sharing, caring, helping, and donating on the other hand. The likelihood of a child performing an altruistic or prosocial behavior in any given situation, however, appears to be under the strong influence of situational variables such as the salience of the victim's distress cues, the particular type of help required, and the child's needs and wants at the moment. 


\section{Altruism in Adults}

In the adult literature, altruism has been studied from three major perspectives. One perspective has explored the relationship between self-report measures of personality traits, such as empathy, and subjects' willingness to help in various laboratory situations. Two personality traits that have consistently been related to laboratory helping behaviors are empathy and personal responsibility.

Stiff, Dillard, Somera, Kim, \& Sleight (1988) reported that high scores on empathy measures were related to helping and volunteering in both actual and hypothetical situations. Eisenberg, Miller, Schaller, Fabes, Fultz, Shell, \& Shea (1989) also found a positive relationship between empathy, social responsibility, and willingness to help a needy family that could not be accounted-for by subjects' concerns about appearing socially desirable.

According to Carlo, Eisenberg, Troyer, Switzer, and Speer (1991), when distress cues were subtle, subjects scoring high on dispositional altruism (empathy, responsibility, helpfulness) were more likely than others to assist a distressed peer. Subjects high on dispositional altruism were also more likely to offer assistance when escape (i.e., leaving the situation without being criticized) was an easily available option. Fritzsche and Penner (1992) similarly found that altruistic personality characteristics moderated the effect of situation on college students' willingness to help a friend in a hypothetical dilemma. Most subjects in this study reported that the closer the date of a scheduled exam, the less likely 
they were to spend time comforting a distressed friend. However, subjects scoring high on "altruistic personality" were not affected by the nearness of the exam; they were equally willing to help even when the cost of helping was high.

A second approach to investigating the motivators underlying altruistic behavior in adults has involved manipulating intrapersonal states via experimental conditions. For example, Batson, Batson, Slingsby, Harrell, Peekna, \& Todd (1991) induced "situational empathy" by instructing subjects to imagine what a character in a film was feeling. In another study (Batson, O'Quin, Fultz, Vanderplas, \& Isen, 1983), situational empathy was monitored by asking subjects to report on their levels of concern and distress at various points during the experiment. Eisenberg, Fabes, Miller, Fultz, Shell, Mathy, and Reno (1989) monitored facial expression, self-reported sympathy, and heart-rate while subjects watched an emotionally moving videotape. The personality variables that were most often related to helping behaviors in these studies were empathy and social responsibility.

Related studies (i.e., Batson, Batson, Griffitt, Barrientos, Brandt, Sprengelmeyer, \& Bayley, 1989; Batson, Dyck, Brandt, Batson, Powell, McMaster, \& Griffitt, 1988) explored interactions between empathy and personal distress. These investigators reported that although many empathically aroused subjects offered to help a distressed confederate when the subjects could not easily avoid or escape from the situation, subjects demonstrating relatively high empathy in conjunction with relatively low personal distress were more likely to 
volunteer to help in another condition, when escape was made easy. These findings suggest that a potential altruist's ability to think constructively may be an important determinant of whether help will actually be offered in any given situation.

A third approach to studying the relationship between altruistic personality variables and altruistic behavior in adults involves surveys and interviews of altruists, helpers, and volunteers from a wide array of circumstances. For example, in a landmark retrospective study, Oliner and Oliner (1988) noted that a number of personality and family-background variables discriminated between Holocaust rescuers and nonrescuers. The key differences were: empathy for pain, sense of personal responsibility for others' welfare, sense of self-efficacy, internal locus of control, absence of ethnic prejudice, attachment to parents, parents' fair and contingent discipline methods, and parents' emphasis on moral values.

Monroe (1991) recorded extensive qualitative interviews with Holocaust rescuers, nonrescuers, Carnegie Heros, American philanthropists, and American entrepreneurs. She concluded that the only difference among these groups was in the rescuers' unique cognitive schemas, in which they perceived themselves as "...one with all mankind (ic $) "$. Monroe hypothesized (Monroe, 1991; Monroe \& Epperson, 1994), that cognitive schema mediates one's perceptions of situational demands, leading both rescuers and bystanders to explain their vastly different behaviors in terms of "What else could I do?" 
Colby and Damon (1992), using qualitative analyses of interviews with 23 moral exemplars, identified four variables that appeared to form the core of their respondents' altruistic personalities. These variables are quite similar to those reported by Oliner and Oliner (1988), Monroe (1991), and Monroe and Epperson (1994). They consisted of (1) certainty (i.e., being sure that they are doing the right thing), (2) positivity (e.g., sense of self-efficacy, habits of constructive thinking), (3) unity of self and moral goals (e.g., personal responsibility for their own moral behavior and for the welfare of others), and (4) an openness to moral growth.

It is worth noting that neither Oliner and Oliner (1988) nor Monroe (1991; Monroe and Epperson, 1994) found significant differences between rescuers and bystanders on the variables of financial condition, living situation, or similar circumstantial conditions, and that many of Colby and Damon's (1992) moral exemplars struggled with financial and other hardships. This suggests that in life, as in the laboratory, adverse circumstances are not sufficient to deter people high in altruistic personality qualities from helping, despite high cost to themselves.

Other field-investigators have studied the motivations of people volunteering to donate blood (Piliavin \& Libby, 1985/1986), donate kidneys (Borgida, Conner, \& Manteufel, 1992), care for AIDS victims (Snyder \& Omoto, 1992), engage in crisis counseling (Clary \& Miller, 1986), or participate in civil rights freedom marches (Rosenhan, 1970). Personality variables that tended to 
be associated with altruism in these studies included empathy, a strong sense of personal responsibility, ability to remain optimistic and think constructively under stress, and internalized values of justice and/or care. In addition, many had developed a habit (or norm) of particular types of helping.

\section{Parenting Variables Related to Altruism}

Hoffman $(1979,1988,1989)$ proposed that socialization experiences play a central role in determining whether a child's innate empathic tendencies develop into adult altruistic behaviors. Investigations of socialization experiences have included laboratory studies with children, field-based observations of parents and children, and adults' retrospective reports of their parents behaviors.

Laboratory studies tend to focus on one socialization method at a time, and typically involve interactions with strange adults in artificial situations. Follow-up of children's behavior in their natural environment suggests that although the socialization methods investigated in laboratory studies may be related to prosocial behavior, there is no assurance that children actually learn and maintain prosocial behaviors by these methods in the real world. For example, Grusec, Kuczynski, Rushton, and Simutis (1978) studied the effects of attributions on children's sharing behaviors. Children who were told that their generosity was a result of their own internal motivation to be helpful were more likely to share (and to continue sharing over a period of three weeks) than were children who were told that they had shared because the experimenter had expected them to do so. This finding suggests a link between parents' 
attributions and development of adult altruists' sense of responsibility for others' welfare. However, an observational study of four-and seven-year olds in their homes (Grusec, 1991) indicated that parental statements of character attribution in response to their children's spontaneous prosocial behavior occurred only minimally in everyday interactions. In addition, four-year olds whose prosocial behavior was most frequently followed by no response tended to be the most prosocial, suggesting that although adults' attributions can increase prosocia! behavior, they may not be the mechanism by which prosocial behavior is actually developed in natural situations.

In other laboratory studies of the development of altruism, Rushton (1975; Rushton \& Littlefield, 1979) found that children's altruism was durable for two months after watching an adult model. However, in a more natural setting, their altruism did not generalize to slightly different categories of behavior. That is, children who observed a model donating to poor children were more likely to donate to poor children, but were not more likely to share with their peers. These outcomes suggest caution in interpreting the results of laboratory studies on the acquisition and maintenance of prosocial behavior.

Field-based studies of the relationship between everyday parent-child interactions and children's competence are more difficult to conduct and interpret. A major series of investigations in this area was conducted by Baumrind (1967, 1971, 1973, 1978, 1989, 1991a, 1991b). One measure of social competence that was included in Baumrind's studies was "social 
responsibility," which included prosocial qualities such as friendliness, thoughtfulness, helpfulness, self-control, and dependability (Baumrind, 1989; Baumrind \& Black, 1967). Baumrind consistently found a positive relationship between authoritative (i.e., warm, firm, and democratic) parenting practices and both assertiveness and social responsibility in offspring. Authoritative parenting involves a combination of parental warmth (i.e., modeling empathy and the ethic of care), close parental supervision (i.e., insistence on the child's personal responsibility for her actions), and democratic methods of setting rules and determining consequences (i.e., a relationship based on the ethic of justice). Investigators studying adult altruists have noted similar relationships between parental warmth, acceptance, and firmness during childhood, and subjects' altruistic personality variables in adulthood. Barnett, Howard, King, \& Dino (1980) found that college students high in empathy reported that their parents spent more time with them, were more affectionate with them, and discussed feelings more often than had parents of less empathic students. In a rare longitudinal study, Koestner, Franz \& Weinberger (1990) compared parenting behaviors that were observed when subjects were five years old with subjects' personalities at age 31. Empathy at age 31 was related to paternal involvement in childcare, maternal tolerance of dependent behavior, and maternal inhibition of children's aggression. These findings support the hypothesis that Baumrind's dimensions of authoritative parenting are related to the development of empathy in adulthood. 
Surveys of rescuers, volunteers, and social activists have also supported a relationship between authoritative parenting practices and altruism. Parenting variables that were related to altruistic behavior in these studies include parental warmth, parental involvement, and inductive (i.e., communicative, rather than punitive) methods of discipline. For example, in Clary and Miller's (1986) study of crisis center volunteers, the most committed volunteers were those who reported warm, positive relationships with altruistic parents, and in Rosenhan's (1970) investigation of volunteer civil rights activists, "fully committed freedom riders" described more positive relationships with their parents than did partially committed freedom riders. In qualitative studies, adult altruists described parental values of justice and care, and parents' willingness to act on those values, as influential in their development (Colby \& Damon, 1992; Monroe, 1991; Monroe \& Epperson, 1994; Oliner \& Oliner, 1988; Rosenhan, 1970, 1972). Even among child activists, Coles (1986) noted the role of parental support and modeling of moral strength, and Hart and Fegley (in press) found that adolescent care exemplars were more likely to model themselves after their parents than were a matched set of control subjects.

\section{Methodological Issues}

Large scale, longitudinal studies of the relationship between childhood personality, parenting practices, and adult altruism would be ideal, but they are obviously complicated and difficult, and therefore quite rare. In addition, before embarking on such an ambitious undertaking, the investigator must have in mind 
a fairly reliable set of variables most likely to be related to adult altruism.

Although there have been many investigations of different aspects of altruism, few studies have combined personality, parenting, and behavioral variables in a way that might yield such a set of variables. Field-based surveys of adult altruists (e.g., Colby \& Damon, 1992; Monroe, 1991; Oliner \& Oliner, 1988) have attempted to explore the network of relationships among personality characteristics, family background variables, and expressions of altruism. Analysis of the data from these studies, however, uncovers a number of methodological problems. For example, the Oliners' (1988) methodology relied primarily on multiple chi-square and ANOVA analyses of hundreds of interview questionnaire responses by Nazi-era rescuers and bystanders, all gathered long after World War II, and therefore subject to retrospective modification.

Repeated use of the .05 significance level in post-hoc analyses increases the risk of "familywise error rate" (Keppel, 1991), i.e., the probability that some comparisons may appear significant simply on the basis of chance. In addition, the analyses used by Oliner and Oliner dealt with only one measured variable at a time; statistical relationships among combinations of variables were not reported.

The sample sizes in Monroe's (1991) comparative interviews of altruists and entrepreneurs, and of Holocaust rescuers (Monroe \& Epperson, 1994) were too small to analyze statistically. Her conclusions were based on qualitative analyses which contribute much to the understanding of the process, but do not 
address representativeness or generalizability. Colby and Damon's (1992) illuminating study of 23 moral exemplars was also a qualitative analysis, and had no control group.

Laboratory studies of altruism have had the advantage of tighter experimental control, but have not typically explored a combination of personality, parenting, and altruistic behavior variables at once, and often used contrived measures of altruism.

The current investigation combines both personality and parenting variables to predict real-life altruism in a multivariate design, with a sizable college-age population, across four major universities. Unlike many laboratory studies of altruism, the focus of this study is on sustained, planned altruistic behavior in the form of organized volunteer work, rather than isolated instances of helpfulness. Although the outcome variable, volunteer work, is assessed via self-report, precautions were taken, such as distributing questionnaires through campus-based volunteer organizations and requiring subjects to list the name of the volunteer organization, to help ensure the reliability and validity of the outcome measure.

\section{Summary}

In summary, altruism in adults, and prosocial behaviors in children, have been robustly related to personality variables of empathy (Batson et al., 1988; Batson et al., 1989; Batson et al., 1991; Eisenberg, Fabes, et al., 1989; Eisenberg, Miller, et al., 1989; Hoffman, 1989; Oliner \& Oliner, 1988), ascription 
of responsibility to oneself (Chapman et al., 1987; Monroe, 1991; Oliner \& Oliner, 1988; Schwartz, 1968), and internalized moral values of justice and care (Blasi, 1980; Colby \& Damon, 1992; Eisenberg \& Mussen, 1989; Oliner \& Oliner, 1988; Schwartz \& Howard, 1984). In addition, prosocial behavior in children and altruistic behavior in adults have been related to a sense of competence or egostrength, and to a tendency to think constructively under stress (Colby \& Damon, 1992; Midlarsky, 1984; Midlarsky \& Hannah, 1985; Oliner \& Oliner, 1988;

Peterson, 1983).

Certain parenting practices have also been related to prosocial behavior in children and to empathy or altruism in adults. These include warm but firm disciplinary practices (e.g., supervision versus permissiveness, Baumrind, 1967 , 1989, 1991; Eisenberg \& Mussen, 1989), and parents' expressiveness of warmth or empathy (Barnett et al., 1980; Koestner et al., 1990; Rosenhan, 1970, 1972; Zahn-Waxler, Radke-Yarrow, \& King, 1979; Zahn-Waxler, Radke-Yarrow, Wagner, \& Chapman, 1992). In addition, a relationship has been noted between altruistic behavior in adults and parental emphasis on values of justice and/or care (Colby \& Damon, 1992; Oliner \& Oliner, 1988; Rosenhan, 1970, 1972).

Altruism, in this study, is defined as college students' current participation in unpaid, unremunerated, volunteer work for a minimum of one hour per week. Support for the use of volunteers as altruists comes from Clary and Snyder's (1991) review of the literature on volunteerism. They reported that although volunteers may cite a variety of motivators for their volunteer work, altruistic (as 
opposed to egoistic) reasons are a consistent, and primary, motive across different types of volunteer work and different ages of volunteers. In addition, consistent volunteer work for an organization represents a sustained, planned form of altruism, rather than an isolated instance of helpfulness.

The hypotheses investigated in this study are:

1. Altruism in college students is related to prosocial personality variables of empathy, responsibility, and moral reasoning.

2. Altruism in college students is related to constructive thinking.

3. Altruism in college students is related to one or more aspects of authoritative parenting practices (i.e., to parental warmth, parental supervision, or parental willingness to respect children's judgment).

The predictions that follow from these hypotheses are that (a) self-report measures of prosocial personality, (b) self-report measures of constructive thinking, and (c) retrospective reports of parenting practices will discriminate college student volunteers from non-volunteers. 


\section{Chapter III}

Method

\section{$\underline{\text { Subjects }}$}

Participants in this study were 518 undergraduate students attending four major New England universities. Three of the universities were private, urban or suburban schools. The fourth was a public university located in a small town.

At each university, at least one campus-based altruistic volunteer organization was targeted, for a total of five altruistic volunteer organizations. The remaining participants were undergraduate students who may or may not have been engaged in altruistic volunteerism at the four universities. Minority group members, and subjects of both genders were actively recruited. Details of the number of students from each university, by gender and by type of volunteer organization, are presented in Table 1.

Table 1

Breakdown of Subjects by Volunteer Status, University, and Gender

\begin{tabular}{|c|c|c|c|c|c|c|c|c|c|}
\hline \multirow[b]{2}{*}{ University } & \multicolumn{3}{|c|}{$\begin{array}{l}\text { Targeted } \\
\text { altruistic } \\
\text { volunteers }\end{array}$} & \multicolumn{3}{|c|}{$\begin{array}{c}\text { Other } \\
\text { undergraduates }\end{array}$} & \multicolumn{2}{|c|}{ Total $\$$} & \multirow{2}{*}{ Subjects } \\
\hline & $\bar{M}$ & $F$ & combined & $\mathrm{M}$ & $F$ & combined & $\bar{M}$ & $\mathbf{F}$ & \\
\hline \#1: Metropolitan, private & 2 & 13 & 15 & 46 & 64 & 110 & 48 & 77 & 125 \\
\hline \#2: Suburban, private & 7 & 15 & 22 & 39 & 47 & 86 & 46 & 62 & 108 \\
\hline \#3: Urban, Ivy league & 7 & 35 & 42 & 55 & 70 & 125 & 62 & 105 & 167 \\
\hline \#4: Small town, public & 13 & 13 & 26 & 12 & 31 & 43 & 25 & 44 & 69 \\
\hline TOTALS: & 29 & 76 & 105 & 152 & 212 & 364 & 181 & 288 & 469 \\
\hline
\end{tabular}

Note: Targeted altruistic volunteers were recruited from campus-based service or rescue organizations; "other undergraduates" were recruited in student unions, cafeterias, and classes. Additional information about Universities is listed in Appendix D. 


\section{Measures}

All measures were self-report instruments, with answers presented in Likert-type format, ranging from two to five response choices. The scales were arranged so that in all instances, higher scores represented greater endorsement of the trait or activity.

Prosocial Personality Battery (PSPB) (Fritzsche \& Penner, 1992; Penner \& Fritzsche, 1992). The PSPB is a composite of four measures that have predicted helping behavior in previous research: (1) the Interpersonal Reactivity Index (Davis, 1980, 1983), composed of three subscales, (2) the Ascription of Responsibility Scale (Schwartz, 1967, 1968), (3) moral reasoning questions based on research by Dyck, Batson, Oden, and Weeks (1989) and Ford \& Lowrey (1986), and (4) The Self-Report Altruism Scale (Rushton, Chrisjohn, \& Fekken, 1981). Penner (personal communication, February, 1993) administered these four measures, composed of six subscales, to 1,018 college students, and condensed them based on factor analysis (i.e., by dropping individual questions from each of the various subscales that did not load significantly on either of the two major factors that emerged). This resulted in a shortened version of six subscales with 56 items.

The personality characteristics that the PSPB is designed to assess are: three types of empathy ("empathic concern," "perspective-taking," and "personal distress"), two modes of moral reasoning (higher levels of justice reasoning, and moral reasoning based on the ethic of care), the tendency to accept 
responsibility for one's actions, and the tendency to be helpful to others in everyday life.

To assess the three types of empathy, Penner \& Fritzsche drew on three subscales from the Interpersonal Reactivity Index (Davis, 1980, 1983):

(a) Empathic Concern, i.e., concern for unfortunate others, consisting of 7 items such as "I often have tender, concerned feelings for people less fortunate than me," $\alpha$ reported by Penner, (February, 1993) $=.78$.

(b) Perspective Taking, i.e., the tendency to see situations from the other person's viewpoint, consisting of 7 items such as "Before criticizing somebody, I try to imagine how I would feel if I were in their place," $\alpha$ reported by Penner, (February, 1993) $=.74$

(c) Personal Distress, i.e., self-oriented feelings of personal anxiety and unease in tense interpersonal situations, consisting of 5 items such as "In emergency situations, I feel apprehensive and ill-at-ease," $\alpha$ reported by Penner, (February, 1993) $=.76$.

To assess the tendency to make interpersonal decisions based on otheroriented or mutuality-based moral reasoning vs. self-centered reasoning, the PSPB contains eight moral reasoning items based on research by Dyck, Batson, Oden, and Weeks (1989) and by Ford \& Lowrey (1986). These items reflect both justice- and care-based moral reasoning, and consist of statements such as "My decisions are usually based on what is the most fair and just way to act" and 
"I choose alternatives that are intended to meet everybody's needs." (Reliability estimates were not reported).

The tendency to accept responsibility for one's actions is assessed on the PSPB via 15 items from the Ascription of Responsibility Scale (Schwartz, 1967, 1968). Items include statements such as "No matter how much a person is provoked, they are always responsible for whatever they do." The original Ascription of Responsibility Scale (Schwartz, 1967) consisted of 24 items administered to 118 college men, which rated a Kuder-Richardson reliability coefficient of .67 and a $7-10$ month test-retest reliability estimate of .63 ( $\underline{N}=109)$. Penner's reliability estimate for his shortened form of this scale was $\alpha=.77$ (Penner, personal communication, February, 1993). Schwartz reported a low correlation of -.01 between ascription of responsibility and social desirability (measured by Crowne \& Marlowe's Social Desirability Scale), suggesting that responses on the Ascription of Responsibility Scale were not seriously influenced by one's desire to appear socially appropriate. For the current study, the gender-biased wording of some items on the Ascription of Responsibility portion of the PSPB was adjusted by substituting gender-neutral pronouns, to enable both women and men to relate equally to the questions.

The last portion of the PSPB consists of 14 items from The Self-Report Altruism Scale (SRA; Rushton, Chrisjohn, \& Fekken, 1981), such as "I have donated goods or clothes for a charity." The SRA measures self-reported frequency of actual helping behaviors, and as such is not precisely a personality 
measure. Because the SRA questions are redundant with key outcome variables used in this study (i.e., self-reported number of hours spent helping others), the SRA questions were not used in this study.

According to Penner and Fritzsche, the PSPB consists of two moderately correlated factors: 1) Empathy/Other Oriented and 2) Helpfulness. The Empathy/Other Oriented factor consists of the Perspective Taking, Empathic Concern, Ascription of Responsibility, and Moral Reasoning subscales. The Helpfulness factor consists of the Self-Report Altruism Scale (SRA) and the Personal Distress subscale (which has a negative loading).

Three-week test-retest reliability estimates for the PSPB were reported as .84 for factor one (Other Oriented/Empathy) and .87 for factor two (Helpfulness) $(\underline{N}=500 ;$ Penner, personal communication, February, 1993).

The construct validity of the PSPB was examined in a series of studies with college students (Penner, personal communication, February, 1993). Significant correlations were reported in two studies $(\underline{N}=698$ and $\underline{N}=192)$ for both the Other Oriented/Empathy factor and the Helpfulness factor of the PSPB with the Helping Orientations Questionnaire (Romer, Gruder, \& Lizzadro). In a third study $(\underline{N}=162)$, the two factors of the PSPB were significantly correlated with thoughts and feelings about perceived costs of helping. In a fourth study, both factors of the PSPB were able to differentiate volunteers working for a homeless organization from non-volunteers $(\underline{N}=112)$. In a fifth study $(\underline{N}=74)$, the Helpfulness factor of the PSPB was significantly correlated with acts of 
helpfulness performed six weeks later. In a sixth study (Fritzsche \& Penner, $1992 ; \underline{N}=207$ ), both factors of the PSPB were correlated with subjects' likelihood of helping a friend in distress under various hypothetical cost/benefit scenarios (e.g., closeness of an exam, amount of time required, requester's deservingness). In addition, significant interactions between the Helpfulness factor and two of the circumstantial cues (closeness of the exam and amount of time requested) discriminated high from low altruists.

Constructive Thinking Inventory (CTI; Epstein \& Meier, 1989). The CTI is a self-report measure that asks about one's typical thoughts during challenging situations. Sample questions include, "When faced with a large amount of work to complete, I tell myself I can never get it done, and feel like giving up," and "If I said something foolish when I spoke up in a group, I would chalk it up to experience and not worry about it."

The CTI was normed on 1,500 university students. The complete CTI consists of six content scales and two lie scales, for a total of 108 questions. Because the complete $\mathrm{CTI}$ is lengthy, and because its minor scales are not directly relevant in a study of altruism, an abbreviated version (the Global Constructive Thinking Scale) was used. The Global Constructive Thinking Scale (GCT) consists of 29 questions representing emotional and behavioral coping. Cronbach's alpha for the GCT Scale is .90 (Epstein, personal communication, January 20, 1993). 
Support for construct validity for the Global Constructive Thinking Scale of the CTI was reported in terms of significant correlations with a variety of criteria of success in living (Epstein \& Meier, 1989) such as success in love and social relationships, psychological symptoms, physical symptoms, self-discipline problems, and alcohol and drug problems. Support for divergent validity was reported in terms of no significant correlations between CTI scales and academic achievement. Katz and Epstein (1991) also reported that poor constructive thinkers produced more negative affective and poorer cognitive responses than did good constructive thinkers in a laboratory situation, particularly during a stress period.

Authoritative Parenting Index (Steinberg, Mounts, Lamborn, \& Dornbusch, 1991). This instrument was designed to assess the three dimensions of parenting found by Baumrind (1973) to be important in rearing competent children: warmth versus neglect, firmness versus permissiveness, and a democratic versus autocratic approach. This instrument was developed as a self-report questionnaire for high school students. Questions were therefore reworded to the past tense for this study, and subjects were instructed to respond to the items based on their parents' behaviors during the subject's last two years of high school.

The Authoritative Parenting Index consists of three empirically derived subscales:

a) Acceptance/involvement: 9 items intended to reflect parental warmth, such as "I could count on my parents to help me out if I had some kind of 
problem." Reliability estimate reported by Steinberg et al. (1991) for a large sample of high school students was $\alpha=.72$.

b) Behavioral control: 9 items intended to reflect parental firmness and supervision, such as "In a typical week, what was the latest you could stay out on school nights?" $\alpha$ reported by Steinberg et al. $(1991)=.76$.

c) Psychological autonomy granting: 8 items intended to reflect a democratic approach and parents' moral value of justice:, such as "My parents let me make my own plans for things I wanted to do," $\alpha$ reported by Steinberg et al. $(1991)=.72$.

Although the Authoritative Parenting Index was designed as an instrument for high school students, it appears appropriate for retrospective use with college-age subjects for a number of reasons: (1) subjects in this study were only a few years older than the subjects upon which the instrument was developed, (2) scoring of this instrument is based on relative standing within each sample, and not on a national norm, and (3) a study that investigated the retrospective use of a similar instrument (the Family-of-Origin version of the Family Functioning Scale, Green, 1991) reported that the Family-of-Origin version replicated the original instrument's factor structure and that it resulted in similar Cronbach alpha reliability estimates of .82 to .93 for subscales.

Support for construct validity of the Authoritative Parenting Index comes from a longitudinal study (Steinberg, Lamborn, Dornbusch, \& Darling, 1992) of over 6,000 high school students, in which authoritative parenting predicted adolescents' school success.

Self-report questions developed for this study. Additional self-report questions were developed for this study to assess the frequency of activities 
related to career goals, socialization, altruism, and rescue over the past year, and to determine level of pre-university involvement in volunteerism. Responses were arranged on a Likert-type scale with number of hours or number of times performed. For example, the question designed to assess level of altruistic volunteerism asked the respondent to self-report how many hours each week were spent in "unpaid volunteer work that benefits people in need, or the environment." A lengthy list of examples followed. Respondents chose among five replies: (a) none, (b) an average of about 1-2 hours a week, (c) an average of about 3-4 hours a week, (d) an average of about 5-6 hours a week, (e) an average of about 7 or more hours a week. To discourage misrepresentation, respondents were requested to write the "name or type of organization" on the next line.

The purpose of these questions was 1) to assess the level of altruistic volunteerism among respondents, 2) to determine whether subjects who were not members of one of the targeted volunteer groups might be volunteers for other organizations, and 3) to explore potential differences between nonvolunteers and volunteers at different levels of involvement/commitment.

In addition to the above questions, data were collected on subjects' age, gender, year in college, number of hours spent in paid employment, number of hours spent on family obligations, position in family, college major, current participation in other (non-altruistic) organizations, hours spent informally 
helping family, friends, or neighbors, and hours of community service in high school.

\section{Procedure}

The first stage of this study involved conducting a pilot study using the measures. Although most measures (questionnaires and Likert-type scales) had been validated by other investigators, a few additional questions had been developed for this study. The entire questionnaire was administered to ten participants at one university. Participants were remunerated with course credit. The length of time needed to complete the questionnaires was noted (25 to 30 minutes), and participants' comments were solicited. As a result of these comments, the criteria for classifying subjects as "altruistic" volunteers were refined. For the purposes of this study, "altruistic volunteers" were defined as subjects who reported spending at least one hour per week in unpaid volunteer work for an organization that helps those who cannot effectively help themselves--e.g., disenfranchised, disadvantaged, handicapped or fearful people, children, animals, or the environment. Data obtained from pilot stage questionnaires were not used in subsequent analyses.

In the second stage, questionnaires and a written statement about the study were delivered to directors of five campus-based social service or emergency rescue volunteer organizations at four universities. Each of these targeted volunteer organizations met the definition of "altruistic volunteerism" that was established during the pilot phase. The data-collection form was 
entitled "School and Home Questionnaire" and was described as an attempt to learn about what university students think and how they spend their time. Participation was emphasized as voluntary. All directors had been previously contacted and had indicated a willingness to participate. A small honorarium (\$2.00 per completed questionnaire) was donated to the targeted volunteer organization when the completed questionnaires were returned to the investigator.

The volunteer directors distributed the questionnaires to their members with a standardized written or verbal request for participation. Completed questionnaires were returned either directly to the investigator (via mail) or in sealed envelopes to the volunteer program directors. Subjects' responses were anonymous. An additional, optional page asked subjects to provide their names and addresses if they were (a) interested in receiving a summary of the study's results and/or (b) willing to be contacted at some point in the future for a followup study. One hundred and five questionnaires were collected from subjects in targeted volunteer organizations.

The remaining four hundred and three questionnaires were completed at the four universities by undergraduate students who may or may not have been engaged in altruistic volunteerism. At three of the four universities, questionnaires were distributed to undergraduate students in the cafeteria or student union, or through various non-altruistic clubs (e.g., sports teams, chess club, etc.). These participants were paid a $\$ 2.00$ honorarium for each completed 
questionnaire. At the fourth university, participants who were not members of the targeted altruistic volunteer organizations were solicited from undergraduate Psychology classes, and were remunerated with course credit for completing the questionnaire. At all four universities, the study was described as an attempt to learn about what university students think and how they spend their time. Instructions for participants from cafeterias, clubs, or classes were the same as those given to participants from altruistic volunteer organizations.

Institutional Review Board approval. This study was approved by the institutional review boards and/or administrators at all four universities, and signed consent forms were obtained from all participants. Questionnaires were returned to the principal investigator or to her assistant in person or by mail. The consent forms and the optional requests for follow-up information (bearing participants' names and addresses) are stored separately from the data. Copies of these materials are included in Appendices A-C. 


\section{Chapter IV}

\section{Results}

The data collected in this study were self-report questionnaires that included six measures of personality characteristics (empathic concern, perspective-taking ability, sense of personal responsibility, personal distress in response to emergencies, moral reasoning style, and constructive thinking), three retrospective measures of parents' parenting style (parental involvement and acceptance, willingness to grant psychological autonomy, and control over subjects' behaviors), and questions about recent behaviors such as risking one's life to rescue others, informal helpfulness, and volunteerism in high school.

Five-hundred and eight questionnaires were collected from four major New England universities. Twenty-five questionnaires were discarded because the respondents were not matriculated students or were not between the ages of 18 to 23 . Of the remaining 483 questionnaires, fourteen (under $3 \%$ ) were discarded due to substantial amounts of missing data. Thirty five questionnaires that were missing one or two scores on one or two of the personality or parenting scales were retained, and the missing scores were estimated based on the subject's mean score for that scale. Ten questionnaires lacked answers to some of the demographic questions, and were therefore excluded from analyses involving those questions. Eleven subjects who reported volunteer hours for an organization that "benefits people in need" listed an organization that did not fit the criterion of an "altruistic volunteer organization" that was 
established during the pilot phase. That is, they did not serve those who could not effectively help themselves, but instead volunteered for organizations such as student government, band, student newspaper, or major political parties. Credit for their volunteer hours was therefore recorded under the category of "career-advancement" rather than as altruistic volunteer work.

The 469 questionnaires that were used in this study thus represent matriculated undergraduates, 18 to 23 years of age, from the four New England universities. One-hundred and five of these questionnaires were gathered from five targeted altruistic organizations; 364 were gathered from students recruited in cafeterias, students unions, recreational groups, or classes.

Results of this study will be reported in four sections: 1) demographic data, 2) preliminary analyses, 3) main analyses, and 4) additional findings. Analyses were accomplished via SPSS/PC+, Version 4.0.1 (Norusis, 1990). To adjust for uneven cell sizes in factorial analyses, the sequential method of partitioning sums of squares was used, with volunteer work entered as the first factor.

\section{Demographic Data}

Four hundred and sixty-nine questionnaires were used in this study. Onehundred and five of those were drawn from targeted campus-based altruistic volunteer organizations in which students are required to commit to at least one hour of volunteer work per week. The remaining 364 questionnaires were completed by students recruited in cafeterias, student unions, sports activities, 
or classes. Details of the number of students from each university by gender and by type of volunteer organization were reported earlier, in Table 1.

The following descriptive statistics represent the sample of 364 students across four universities who filled out questionnaires in student unions, cafeterias, sports or fraternal organizations, or classes. Responses from students in the targeted volunteer organizations are included in Table 2, but not in the following narrative.

Twenty-six percent (95 of the 364 students) reported "at least 1 hour per week" of volunteer work for an altruistic volunteer organization over the past year. Six of these students $(2 \%$ of 364$)$ volunteered for emergency rescue organizations (fire or ambulance squads), and 89 ( $25 \%$ of 364 ) volunteered for other types of altruistic organizations.

Thirty-three percent (145) claimed to spend at least one hour per week helping others informally (e.g., taking care of neighbor's children for free) over the past year. This category was separate from organized volunteer work, thus someone could donate time to both and claim hours for both questions.

Forty-nine percent (176) claimed to spend at least one hour in either organized volunteer work or informal helping over the past year.

Thirty-two percent (115) reported risking their lives to rescue others at least once in their lifetime. Sixty-one of these 115 subjects (i.e., 17\% of 364) reported that they risked their lives two or more times in order to rescue others. 
Thirty percent $(78)$ reported spending eight hours or more per month in community service volunteer work while in high school. This category could include community or social service work done to fulfill course, religious, or similar requirements, provided there was no monetary stipend. The remaining subjects were almost evenly divided between those who reported spending about 1 hour per month ( $21 \%), 2-4$ hours per month ( $26 \%)$, and 5-7 hours per month $(20 \%)$ in community service volunteer work while in high school.

Seventy-four percent (270) reported involvement with at least one organization over the past school year.

Table 2

Demographic Data With and Without Targeted Altruistic Volunteers

\begin{tabular}{|c|c|c|c|c|c|c|}
\hline \multirow[b]{2}{*}{ ACTIVITIES REPORTED } & \multicolumn{2}{|c|}{$\begin{array}{l}\text { Ss from cafeterias, } \\
\text { student unions, } \\
\text { classes, etc. } \\
(N=364)\end{array}$} & \multicolumn{2}{|c|}{$\begin{array}{l}\text { Ss from targeted } \\
\text { altruistic volunteer } \\
\text { organizations } \\
(N=105)\end{array}$} & \multicolumn{2}{|c|}{$\begin{array}{c}\text { Total across all } \\
\text { subjects } \\
(N=469)\end{array}$} \\
\hline & number & percent & number & percent & number & percent \\
\hline \multicolumn{7}{|c|}{ ALTRUISTIC VOLUNTEER WORK over the past year } \\
\hline none & 269 & $74 \%$ & 0 & $0 \%$ & 269 & $57 \%$ \\
\hline 1-2 hours per week & 47 & $13 \%$ & 28 & $27 \%$ & 75 & $16 \%$ \\
\hline 3-4 hours per week & 26 & $7 \%$ & 29 & $28 \%$ & 55 & $12 \%$ \\
\hline 5-6 hours per week & 7 & $2 \%$ & 9 & $9 \%$ & 16 & $3 \%$ \\
\hline 7 or more hours per week & 15 & $4 \%$ & 39 & $37 \%$ & 54 & $12 \%$ \\
\hline \multicolumn{7}{|c|}{ TYPE OF ALTRUISTIC VOLUNTEER WORK over the past year } \\
\hline emergency rescue & 6 & $2 \%$ & 26 & $25 \%$ & 32 & $7 \%$ \\
\hline social service or environment & 89 & $24 \%$ & 79 & $75 \%$ & 168 & $36 \%$ \\
\hline none & 269 & $74 \%$ & 0 & $0 \%$ & 269 & $57 \%$ \\
\hline \multicolumn{7}{|c|}{ HOURS OF INFORMAL HELPING over the past year } \\
\hline none & 245 & $67 \%$ & 57 & $54 \%$ & 302 & $65 \%$ \\
\hline 1-2 hours per week & 82 & $23 \%$ & 28 & $27 \%$ & 110 & $24 \%$ \\
\hline 3 or more hours per week & 37 & $10 \%$ & 18 & $17 \%$ & 55 & $12 \%$ \\
\hline
\end{tabular}


Table 2, continued

Demographic Data With and Without Targeted Altruistic Volunteers

\begin{tabular}{|c|c|c|c|c|c|c|}
\hline \multirow[b]{2}{*}{ ACTIVITIES REPORTED } & \multicolumn{2}{|c|}{$\begin{array}{c}\text { Ss from } \\
\text { cafeterias, student } \\
\text { unions, classes, } \\
\text { etc. } \\
(N=364)\end{array}$} & \multicolumn{2}{|c|}{$\begin{array}{l}\text { Ss from targeted } \\
\text { altruistic volunteer } \\
\text { organizations } \\
(\mathrm{N}=105)\end{array}$} & \multicolumn{2}{|c|}{$\begin{array}{c}\text { Total across all } \\
\text { subjects } \\
(\mathrm{N}=469) \\
\end{array}$} \\
\hline & number & percent & number & percent & number & percent \\
\hline \multicolumn{7}{|l|}{ RISKED LIFE TO RESCUE C } \\
\hline never & 248 & $68 \%$ & 70 & $67 \%$ & 318 & $68 \%$ \\
\hline once & 54 & $15 \%$ & 15 & $14 \%$ & 69 & $15 \%$ \\
\hline two or more times & 61 & $16 \%$ & 15 & $18 \%$ & 80 & $17 \%$ \\
\hline
\end{tabular}

HRS. PER MONTH IN COMMUNITY SERVICE IN HIGH SCHOOL

$\begin{array}{lrrrrrr}\text { one or less } & 78 & 21 \% & 8 & 8 \% & 86 & 19 \% \\ 2-7 \text { hours per month } & 167 & 46 \% & 42 & 40 \% & 209 & 45 \% \\ 8 \text { or more hours per month } & 117 & 32 \% & 54 & 51 \% & 171 & 37 \%\end{array}$

CAREER/PROFESSIONAL ORGANIZATIONS OR ACTIVITIES over the past year

$\begin{array}{lrrrrrr}\text { none } & 213 & 59 \% & 52 & 49 \% & 265 & 57 \% \\ 1-6 \text { hours per week } & 106 & 29 \% & 29 & 28 \% & 135 & 29 \% \\ 7 \text { or more hours per week } & 44 & 12 \% & 24 & 23 \% & 68 & 15 \% \\ \text { P SPORTS over the past year } & & & & & & \\ \text { none } & 127 & 35 \% & 47 & 45 \% & 174 & 37 \% \\ 1-6 \text { hours per week } & 151 & 42 \% & 50 & 47 \% & 201 & 43 \% \\ 7 \text { or more hours per week } & 86 & 24 \% & 8 & 8 \% & 94 & 20 \%\end{array}$

OTHER SOCIAL ACTIVITIES over the past year (any type not included above)

$\begin{array}{lrrrrrr}\text { none } & 11 & 3 \% & 3 & 3 \% & 14 & 3 \% \\ 1-6 \text { hours per week } & 144 & 40 \% & 43 & 41 \% & 187 & 40 \% \\ 7 \text { or more hours per week } & 209 & 57 \% & 59 & 56 \% & 268 & 57 \% \\ \text { VEMENT WITH ORGANIZATIONS } & \text { over the past year } & & & & \\ \text { none } & 78 & 21 \% & 0 & 0 \% & 78 & 17 \% \\ \text { member 1 or more organizns } & 270 & 74 \% & 105 & 100 \% & 375 & 80 \%\end{array}$

HOURS IN PAID EMPLOYMENT over the past year

$\begin{array}{lrrrrrr}0-6 \text { hours per week } & 208 & 57 \% & 53 & 50 \% & 261 & 56 \% \\ 7-18 \text { hours per week } & 126 & 35 \% & 42 & 40 \% & 168 & 36 \% \\ 19 \text { or more hours per week } & 29 & 8 \% & 10 & 10 \% & 39 & 3 \%\end{array}$

HOURS OF FAMILY OBLIGATIONS over the past year

\begin{tabular}{lrrrrrr}
$0-4$ hours per week & 339 & $93 \%$ & 95 & $90 \%$ & 434 & $93 \%$ \\
$5-15$ hours per week & 19 & $5 \%$ & 10 & $10 \%$ & 29 & $6 \%$ \\
16 or more hours per week & 4 & $1 \%$ & 0 & $0 \%$ & 4 & $1 \%$ \\
\hline
\end{tabular}

Note. Some totals are less than $100 \%$ due to missing data;

others are over $100 \%$ due to rounding. 


\section{Preliminary Analyses}

The relationship between altruism and eleven variables was examined in this study. The eleven variables were: a) six personality measures (personal responsibility, empathy, perspective-taking ability, personal distress, moral reasoning, and global constructive thinking); b) retrospective measures of parents' behaviors and affect (parental acceptance/involvement, parental willingness to grant psychological autonomy, and parents' control over subjects' behaviors), and c) two questions about past or present pro-social behaviors (hours of high-school volunteerism and current level of helpfulness to friends and neighbors). All eleven variables are either antecedents to college volunteerism or personality characteristics coinciding with college volunteerism, but for purposes of statistical analysis, they were treated as dependent variables in the MANOVAs and MANCOVA.

To assess the reliability estimates of the measures that were used, Cronbach's alphas were computed for each subscale for 464 subjects. The resulting reliability estimates were consistent with reliability estimates reported by other investigators, as described below:

Empathic Concern ( 7 items): $\alpha=.73$ ( $\alpha$ reported by Penner, February, $1993=.78)$.

Perspective Taking ( 7 items): $\alpha=.75$ ( $\alpha$ reported by Penner, February, $1993=.74$ ).

Personal Distress (5 items): $\alpha=.77$ ( $\alpha$ reported by Penner, February, $1993=.76$ ).

Moral Reasoning ( 8 items): $\alpha=.77$ (reliability estimates not reported by Penner). 
Ascription of Responsibility ( 15 items): $\alpha=.65$ ( $\alpha$ reported by Penner, February, $1993=.77$; Kuder-Richardson Reliability estimate reported by Schwartz, 1967, for the original 24 -item scale $=.67$ ).

Constructive Thinking Inventory (Global Constructive Thinking Scale, 29 items): $\alpha=.90$ ( $\alpha$ reported by Epstein, $1992=.90$ ).

Parental Acceptance/Involvement ( 9 items): $\alpha=.80$ ( $\alpha$ reported by Steinberg et al., $1991=.72$ ).

Behavioral Control ( 9 items): $\alpha=.75$ ( $\alpha$ reported by Steinberg et al., 1991 $=.76)$.

Psychological Autonomy-Granting ( 8 items) : $\alpha=.77$ ( $\alpha$ reported by Steinberg et al., $1991=.72$ ).

All variables were evaluated to ascertain whether their distributions were sufficiently normal for multivariate analysis. Scores for personal responsibility, empathy, perspective-taking, personal distress, moral reasoning, global constructive thinking, parental willingness to grant psychological autonomy, parents' behavioral control, and high school volunteerism were sufficiently normally distributed, with skew and kurtosis well below 2.0. The measure of parental involvement/acceptance, however, was sufficiently skewed and kertotic to warrant reflection and logarithmic transformation (c.f., Tabachnick \& Fidell, pp. 84-86). After transformation, the scale for parental involvement/acceptance was reversed, so that higher scores indicated less parental involvement and acceptance.

Univariate and multivariate homogeneity of variance among groups was ascertained for each MANOVA and MANCOVA via examination of cell variancecovariance matrices and Box's $\underline{M}$ statistic (Tabachnick \& Fidell, 1989). Box's $\underline{M}$ 
statistic is a highly sensitive measure of equality of variance/covariance matrices for samples with unequal cell sizes, and is of concern only when its probability level falls below .001 . In other words, despite unequal cell sizes, one need not worry about violations of the multivariate assumption of homogeneity of variance/covariance until the probability of obtaining a particular Box's $\underline{M}$ value is less than .001 .

Because of the small number of subjects reporting " $5-6$ hours" and "seven or more hours" of altruistic volunteer work per week, these categories were combined with the previous category, yielding three levels of altruistic volunteer work for the main analyses: 1) nonvolunteers, 2) altruistic volunteers for 1-2 hours per week, 3 ) altruistic volunteers for three or more hours per week. In some of the follow-up analyses, cell sizes proved to be too small to assure homogeneity of variance/covariance (as indicated by singular cells, and Box's $\underline{M}$ statistic $\mathrm{p} \leq .001$ ) with three levels of volunteer work. Levels of altruistic volunteer work were therefore collapsed for these analyses, and the data were analyzed only in terms of altruistic volunteers vs. non-volunteers, with no distinction among volunteers for number of hours of volunteerism.

Before analyzing the data with regard to the major hypotheses of this study, a number of preliminary steps were taken to assess whether factors other than the hypothesized personality and parenting variables might be affecting volunteer work (and would therefore need to be controlled or otherwise taken into account). 
First, the data were explored to assess whether there were significant demographic differences among subjects at the four universities that might prohibit combining their scores on personality/parenting variables in a single analysis. Significance levels for these comparisons were set at $\underline{\mathrm{a}} \leq .01$ to minimize the likelihood of Type I error due to repeated analyses.

Chi-squares were computed to test the relationship between each of thirteen demographic variables across the four universities. Results of these analyses are reported in Table 3.

Table 3

$\underline{\chi^{2} \text { Comparisons of Demographic Variables Across } 4 \text { Universities }}$

\begin{tabular}{|c|c|c|c|c|c|}
\hline \multirow[b]{2}{*}{ VARIABLE } & \multirow[b]{2}{*}{ Levels } & \multirow[b]{2}{*}{ df } & \multicolumn{3}{|c|}{$x^{2}$ Value } \\
\hline & & & $\begin{array}{l}\text { Non-targeted } \\
\text { Ss }(\underline{N}=364)\end{array}$ & $\begin{array}{c}\text { Targeted } \\
\text { Volunteers } \\
(\mathrm{N}=105)\end{array}$ & $\begin{array}{c}\text { All } \underline{S} s \\
(\underline{N}=469)\end{array}$ \\
\hline $\operatorname{Sex}(M / F)$ & $2 \times 4$ & 3 & 4.11 & 10.76 & 1.04 \\
\hline Academic status & $4 \times 4$ & 9 & $43.44^{\star \star}$ & 9.37 & $38.44^{\star \star}$ \\
\hline Sibs (position in family) & $4 \times 4$ & 9 & 9.17 & 7.70 & 12.14 \\
\hline Hrs. of volunteer work & $5 \times 4$ & 12 & 17.95 & $58.74^{\star \star}$ & $76.13^{\star \star}$ \\
\hline Hrs. informal helping & $5 \times 4$ & 12 & 14.86 & 18.63 & 20.05 \\
\hline Rescued others & $5 \times 4$ & 12 & 13.25 & $49.71^{\star \star}$ & $35.86^{\star \star}$ \\
\hline Hrs. of paid employment & $5 \times 4$ & 12 & 24.35 & 12.22 & $26.77^{\star \star}$ \\
\hline Hrs. of family obligations & $5 \times 4$ & 12 & 16.07 & 13.88 & 20.59 \\
\hline Hrs. in career activities & $5 \times 4$ & 12 & 12.67 & 10.03 & 2.63 \\
\hline Hrs. in other social activs & $5 \times 4$ & 12 & 11.85 & 14.19 & 12.20 \\
\hline Hrs. of H.S. volunteering & $5 \times 4$ & 12 & 7.06 & 14.70 & 7.19 \\
\hline $\begin{array}{l}\text { Hrs. in sports } \\
\text { Involved in an organization }\end{array}$ & $5 \times 4$ & 12 & 17.43 & 10.07 & 24.55 \\
\hline$(\mathrm{Y} / \mathrm{N})$ & $2 \times 4$ & 3 & 2.26 & N/A & 3.06 \\
\hline
\end{tabular}


For the total sample of 469 subjects, significant differences appeared among universities for number of hours per week spent in paid employment, $\underline{x}^{2}$ $(12)=26.77, \underline{\mathrm{g}} \leq .01$, with students from University \#1 reporting working more hours per week than did students from University \#3.

There was only one significant difference among non-targeted subjects at the four universities: a different proportion of freshmen, sophomores, juniors, and seniors was drawn from each university, $\underline{x}^{2}(9)=43.44, \underline{p} \leq .01$. Further examination of these chi-square analyses indicated that the sample of nontargeted students at University \#4 included more sophomores and fewer freshmen and seniors than the other three universities. This was probably due to the fact that at University \#4, subjects were recruited from sophomore-level psychology classes, while at the other three universities, they were drawn from the cafeteria, student union, or clubs.

There were significant differences among targeted volunteers in average hours of volunteer work per university, $\underline{x}^{2}(12)=58.74, \underline{p} \leq .01$, and in number of times subjects risked their lives to rescue others, $\underline{\chi}^{2}(12)=49.71, \underline{p} \leq .01$. More targeted volunteers at University \#4 reported longer hours in weekly volunteer work and a higher frequency of risking their lives to rescue others than did targeted volunteers at the other three universities. This may have reflected the fact that the targeted volunteer organizations at University \#4 were the volunteer ambulance corps and the volunteer fire department, while the targeted volunteer organizations at the other universities were social service organizations. 
The existence of significant differences among subjects from the four universities in the areas of year in college, hours of volunteer work, risking one's life to rescue others, and paid employment suggested caution in combining all subjects into one group when investigating the relationship between volunteer work and scores on the personality/parenting measures. The main analyses were therefore conducted as factorial analyses, with "University" included as a factor in addition to level of altruistic volunteer work.

Next, an additional set of chi square analyses was conducted to investigate whether any of the demographic variables was related to volunteer work. This was done to rule out the possibility that circumstances unrelated to parenting or personality (e.g., the need to support oneself through college) might preclude students from spending time in volunteer work. Scores on each of the demographic variables were compared via chi-square across five levels of altruistic volunteer work (ranging from "no volunteering" through "seven or more hours of volunteering per week"). Results are reported in Table 4.

Among the 469 subjects, there was no significant relationship between level of volunteering and number of hours currently spent in paid employment, family obligations, career, sports, or social activities, or between volunteering and gender. In fact, the rate of volunteerism among students with the most serious financial or family obligations (i.e., those reporting more than 18 hours per week in paid employment or more than 15 hours per week in family 
obligations) was the same or higher than for students with the lowest level of family or employment obligations.

Table 4

$x^{2}$ Comparison of Demographic Variables Across 5 Levels of Volunteer Work

$\operatorname{Sex}(M / F)$

Academic status

Sibs (position in family)

Hrs. of helping

Rescued others

Hrs. of paid employment

Hrs. of family obligations

Hrs. in career activities

Hrs. in other social activs

Hrs. of H.S. volunteering

Hrs. in sports

$\star \star \mathrm{p} \leq .01$.

Note. By definition, targeted volunteers had only 4 levels of volunteer work; df were reduced accordingly.

Thirty-nine subjects (out of 469) reported working at paid employment for more than 18 hours per week; $16(41 \%)$ of those subjects reported altruistic volunteering for one or more hours per week. Two-hundred and sixty-one subjects reported spending under seven hours per week in paid employment; $104(40 \%)$ of them reported one or more hours of altruistic volunteer work per week. For family obligations, the vast majority of subjects (93\%) reported spending less than five hours per week in family obligations. Of the 32 subjects who reported spending more than five hours per week in family obligations, 19 
(60\%) reported spending at least one hour per week in altruistic volunteer work. Ten subjects reported spending more than eleven hours per week in family obligations. Eighty percent of them (eight subjects) reported spending at least one hour per week in altruistic volunteer work: three of them reported volunteering for 1-2 hours per week, and five of them reported volunteering for three or more hours per week.

This finding suggests that financial, social, or family obligations did not preclude students from spending time in volunteer work. There were, however, significant differences across levels of altruistic volunteerism for hours per week spent informally helping neighbors and friends and for past hours of volunteer work performed in high school, with $\underline{x}^{2}(16)=50.87, \underline{\mathrm{p}} \leq .01$, and $\underline{x}^{2}(16)=38.33$, $\underline{p} \leq .01$, respectively. In light of these relationships, scores for helping and for high school volunteering were included as additional dependent variables in the main analyses of this study. Because scores for helping were kurtotic (kurtosis $=3.66)$ a logarithmic transformation was applied to this variable.

The question of whether a general tendency to be sociable could account for undergraduate students' participation in altruistic volunteer organizations was investigated in a number of ways. First, chi-square analyses indicated no significant differences $(\underline{p}>.01)$ in number of hours reportedly spent on career, sports, or purely social activities, regardless of level of altruistic volunteer work (see Table 4). In addition, a composite variable ("socscore") was computed by adding the hours reported for career, sports, and social activities. There was no 
correlation between socscore and altruistic volunteerism for all 469 subjects (see Table 5). These results suggest that sociability, in and of itself, does not explain altruistic volunteer work.

To assess the relationship of organization membership with the 11 variables separate from the effect of membership in an altruistic volunteer organization, an additional analysis was performed, using only subjects who were not altruistic volunteers. This 2-way, $2 \times 4$, MANOVA (Organizational Status by University) compared members of non-altruistic organizations (e.g., sports teams, fraternities, band; $\underline{N}=172$ ) with subjects who reported no organization membership ( $\underline{N}=74$ ) on the personality, parenting, and behavioral variables, across the four universities. Both organization members and nonmembers consisted exclusively of "nonaltruists" -i.e., subjects who were not members of altruistic volunteer organizations. Eleven dependent variables were assessed: nine scores on the personality/parenting measures, high school volunteerism, and informal helping. Results of this analysis are reported in Table 6.

There was a significant main effect for organization (member vs. nonmember), a significant main effect for university, and a significant interaction between organization and university. 


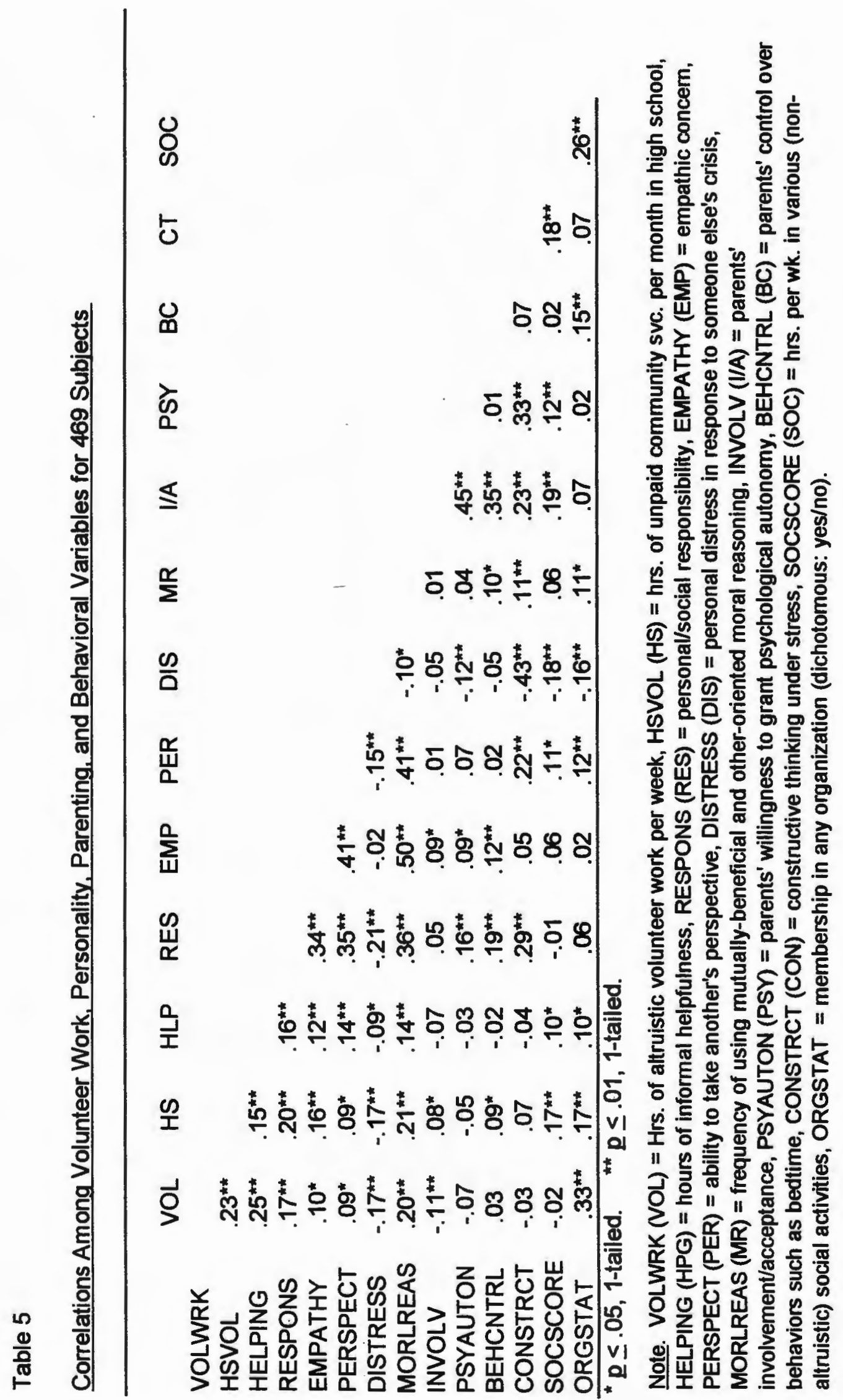


Table 6

Summary Table of MANOVA for Organization and University on 11 Personality, Parenting, and Behavioral Variables, for Nonaltruists $(\mathrm{N}=252)$

\begin{tabular}{lccccc}
\hline Source of Variation & Wilks Lambda & Mult. F & Hypoth df & Error df & Sig. of F \\
\hline Organization & 0.8844 & 2.709 & 11 & 228.00 & .003 \\
University & 0.8055 & 1.552 & 33 & 672.43 & .026 \\
$\begin{array}{l}\text { Organization x } \\
\text { University }\end{array}$ & 0.7788 & 1.805 & 33 & 672.43 & .004 \\
\hline Box's M value $=514.42, \underline{\mathrm{p}} \geq .001$ & & & &
\end{tabular}

See Appendix E for follow-up univariate tests.

Follow-up ANOVAs indicated that the interaction of organization status by university among the nonvolunteers was significant for only one dependent variable, (log of) parental involvement/acceptance, Univariate $E(3,238)=3.99$, $\mathrm{p} \leq .01$ (see Table 15 and Figure 1 in Appendix E). Further analysis of simple effects indicated that there were no differences in level of parental involvement/acceptance among students who were not members of organizations at any of the four universities. However, among organization members, students at University \#3 reported significantly less parental involvement/acceptance than did students at University \#4, $\underline{F}(3,171)=3.05, \underline{p}$ $\leq .05$. In addition, when comparing members vs. nonmembers within each university, University \#1 differed from the other three universities: organization members at University \#1 reported a higher level of parental acceptance/involvement than did non-members, $\mathrm{E}(1,84)=14.99, \underline{\mathrm{p}} \leq .01$. 
Univariate follow-up tests for the significant main effect of organization status (member vs. non-member) yielded significant results for personal distress, $\underline{F}(11,238)=9.00, \underline{\underline{Q}} \leq .01$ and for parents' control over students' behaviors, $\underline{F}$ $(11,238)=9.69, \underline{\mathrm{g}} \leq .01$ (see Table 15, Appendix E). Organization members reported less personal distress in crisis situations than did non-members (group means of 2.25 vs. 2.52 , respectively), and greater parental control over their activities and friendships during high school (group means of 5.62 vs. 5.21 , respectively).

Univariate follow-up tests for the significant main effect of university yielded no variables significantly different across universities at the $\underline{\mathrm{Q}} \leq .01$ level.

The above results suggest that organization membership per se is related to differences in some of the dependent variables that will be tested against the main hypotheses and could therefore be a confounding factor. Because organizational status is a nested variable in this study (i.e., by definition all altruistic volunteers must be organization members, while non-altruists can be either organization members or non-members), its effect could not be eliminated by using it as either a covariate or an additional factor. In light of these complications, the 74 subjects who reported no organization membership were eliminated from further analyses, and altruistic volunteers were compared only with members of non-altruistic organizations.

Next, the data were examined for the effect of gender on the eleven dependent variables. Although the main hypotheses of this study did not 
address the relationship of gender to altruistic volunteerism, the use of variables such as "personal distress" and "empathy," raised the possibility that effects of gender could be confounds in the current study. The independent variable Volunteer Work was collapsed into two levels, volunteer vs. nonvolunteer, for this 3-way analysis in order to preserve sufficient subjects in each cell. Results of this $2 \times 2 \times 4$ MANOVA (Gender by Volunteer Work by University), using only organization members $(\underline{N}=369)$ are reported in Table 7 .

Table 7

Summary Table of MANOVA for Gender, Volunteer Work, and University on 11 Personality, Parenting, and Behavioral Variables ( $\mathrm{N}=369$ )

\begin{tabular}{lcrrrr}
\hline Source of Variation & Wilks Lambda & Mult. F & Hypoth df & Error df & Sig. of F \\
\hline Gender & 0.81563 & 7.048 & 11 & 343.00 & .001 ** \\
Volunteer Work & 0.89112 & 3.810 & 11 & 343.00 & $.001^{\text {** }}$ \\
University & 0.81559 & 2.195 & 33 & 1011.25 & .001 ** \\
Gender x Volunteer Work & 0.96448 & 1.148 & 11 & 343.00 & .323 \\
Gender x University & 0.92086 & .870 & 33 & 1011.25 & .680 \\
Volunteer Work x University & 0.85642 & 1.655 & 33 & 1011.25 & .012 * \\
Gender x Volunteer Work x & & & & & \\
University & 0.89253 & 1.206 & 33 & 1011.25 & .199 \\
\hline
\end{tabular}

Box's $\underline{M}$ Statistic $=1023.69, \underline{p}>.001$

${ }^{*} \mathrm{p} \leq .05{ }^{* *} \mathrm{p} \leq .01$.

The above analysis resulted in a significant main effect for gender, Wilks's lambda $=.82$, approximate $\underline{E}(11,343)=7.05, \underline{p} \leq .01$. Univariate follow-up analyses indicated that three variables were significantly related to gender at the $\underline{\mathrm{p}} \leq .01$ level: women reported higher levels of empathy, $\underline{\mathrm{F}}(1,353)=21.44$, 
parents' behavioral control, $\underline{E}(1,353)=19.17$, and high school volunteering, $\underline{E}$ $(1,353)=11.97$. than did men (see Table 16 in Appendix $E$ for means). There was no 3-way interaction between gender, university, and altruistic volunteer work, and no 2-way interaction between gender and volunteer work or between gender and university ( $\underline{p}>.05)$, indicating that gender was not related to the other independent variables. Gender could therefore be used as a covariate in multivariate analyses with volunteer work and university as factors.

\section{Tests of Main Hypotheses}

The hypotheses proposed in this study were:

1. Altruism in college students is related to prosocial personality variables of empathy, responsibility, and moral reasoning.

2. Altruism in college students is related to constructive thinking.

3. Altruism in college students is related to one or more aspects of authoritative parenting practices (i.e., to parental warmth, parental supervision, and/or parental willingness to respect children's judgment).

To test these hypotheses, a 2-way MANCOVA ( 3 levels of Volunteer Work by 4 Universities) was performed using only those 369 subjects who reported membership in an organization and who were not missing scores for high school volunteering or helping. The three levels of altruistic volunteer work were: nonvolunteers $(\underline{N}=172)$, altruistic volunteers for $1-2$ hours per week $(\underline{N}=73)$, and altruistic volunteers for 3 or more hours per week $(\underline{N}=124)$. The four universities were a second factor, and gender (M/F) was a covariate. There 
were 141 males and 228 females. Dependent variables were: personal responsibility, empathy, perspective-taking ability, personal distress, moral reasoning, (log of) parental involvement/acceptance, parents' willingness to grant psychological autonomy, parents' behavioral control, global constructive thinking, hours spent in high-school volunteer work, and (log of) helpfulness. Results of the omnibus MANCOVA are reported in Table 8.

Table 8

Summary Table of MANCOVA for Volunteer Work and University, for 11 Variables, with Gender as Covariate $(N=369)$

\begin{tabular}{lcccccc}
\hline Source of Variation & Wilks's & \multicolumn{4}{c}{ Hypoth } \\
Lambda & Mult. F & df & Error df & Sig. of F \\
\hline Within Cells Regression (Gender) & 0.8298 & 6.451 & 11 & 346.00 & .001 \\
Volunteer Work (3 levels) & 0.8103 & 3.489 & 22 & 692.00 & .001 \\
University (4 levels) & 0.8259 & 2.073 & 33 & 1020.08 & .001 \\
Volunteer Work x University & 0.7855 & 1.299 & 66 & 1856.85 & .056 \\
\hline
\end{tabular}

Box's M Statistic $=886.38, \mathrm{p}>.001$

The omnibus MANCOVA indicated significant differences in the dependent variables among levels of volunteer work, with Wilks's lambda $=.81$. The combination of dependent variables accounted for about $19 \%$ of the variance $\left(\eta^{2}\right)$ in volunteer work after adjusting for the effect of gender. Gender was significantly related to empathy (adjusted $\underline{R}^{2}=.04, \underline{p} \leq .01$ ), parents' behavioral control (adjusted $\left.\underline{\mathrm{R}}^{2}=.05, \underline{\mathrm{p}} \leq .01\right)$, and high school volunteering (adjusted $\underline{\mathrm{R}}^{2}=$ $.03, \mathrm{p} \leq .01)$, and accounted for approximately $17 \%$ of the overall variance $\left(\eta^{2}\right)$, with Wilks's lambda $=.83$ (see Table 17 in Appendix E). 
Follow-up univariate ANCOVAs for the effect of volunteer work on means of the eleven variables, adjusted for gender, indicated that altruistic volunteers differed from non-volunteers on empathy, personal responsibility, moral reasoning, parental involvement and acceptance, number of hours spent in high school volunteering, and number of hours spent informally helping others (see Table 9; Stepdown $\mathrm{E}$ tests will be discussed later).

Follow-up contrasts compared the two levels of altruistic volunteers (volunteers of 1-2 hours per week, and volunteers of 3 or more hours per week) with nonvolunteers to pinpoint where, and in which direction, the differences lay. Gender was retained as a covariate. Results are reported in Table 10.

There were no significant overall differences between nonvolunteers and altruistic volunteers who volunteered for only 1-2 hours per week. Furthermore, there were no significant differences between nonvolunteers and volunteers of only 1-2 hours per week in univariate tests for any of the eleven variables (see Table 11).

The contrast between nonvolunteers and altruistic volunteers who volunteered for three or more hours per week indicated that the majority of the variance between altruistic volunteers and nonvolunteers occurred at this level, with Wilks's lambda $=.86$, approximate $\underline{E}(11,346)=5.29, \underline{p}<.01$, accounting for about $14 \%$ of the variance $\left(\eta^{2}\right)$. Follow-up univariate F-tests for both contrasts are reported in Table 11. 


\section{Table 9}

Univariate and Stepdown F-tests for Effect of Volunteer Work ( 3 levels) on 11 Variables, with Gender as a Covariate $(N=369)$

\begin{tabular}{|c|c|c|c|c|c|c|}
\hline \multirow[b]{3}{*}{ Variable } & \multirow{2}{*}{\multicolumn{2}{|c|}{$\begin{array}{l}\text { Univariate F } \\
\text { with }(2,356) \mathrm{df}\end{array}$}} & \multirow{2}{*}{\multicolumn{4}{|c|}{ Roy-Bargmann Stepdown F }} \\
\hline & & & & & & \\
\hline & $\mathrm{F}$ & Sig. of $F$ & Hypoth. df & Error of & Stepdown F & Sig. of $F$ \\
\hline EMPATHY & 7.05877 & $.001^{\star \star}$ & 2 & 356 & 7.059 & .001 * \\
\hline PERSDISS & 3.42074 & .034 & 2 & 355 & 3.207 & .042 \\
\hline PERSPECT & 0.697 & .499 & 2 & 354 & .243 & .785 \\
\hline PERSRESP & 6.21186 & $.002 * *$ & 2 & 353 & 3.152 & .044 \\
\hline MORLREAS & 10.0658 & .001 * & 2 & 352 & 4.141 & .017 \\
\hline LOGINVOL & 4.92406 & $.008 * *$ & 2 & 351 & 6.095 & $.002^{* \star}$ \\
\hline PSYAUTON & 1.3642 & .257 & 2 & 350 & .461 & .631 \\
\hline BEHCNTRL & 0.5233 & .593 & 2 & 349 & 609 & .544 \\
\hline GLOBALCT & 1.34968 & .261 & 2 & 348 & 4.011 & .019 \\
\hline HSVOL & 8.22009 & $.001 \star$ & 2 & 347 & 4.484 & .012 \\
\hline LOGHLPG & 8.65632 & $.001^{\star \star}$ & 2 & 346 & 3.971 & .020 \\
\hline
\end{tabular}

** $\mathrm{p} \leq .01$

Multivariate Effect of Volunteer Work ( 3 levels):

Wilks's Lambda $=.81028$, approx. $\mathrm{F}(22,692)=3.48899, \underline{\mathrm{p}}<.01$

Note. Variables were entered in accordance with Hoffman's theory of moral development.

EMPATHY = empathic concern, PERSDISS $=$ personal distress, PERSPECT $=$ perspectivetaking ability, PERSRESP = personal/social responsibility, MORLREAS = moral reasoning style, LOGINVOL = $(\mathrm{log}$ of $)$ parents' involvement/acceptance, PSYAUTON = parents' granting of psychological autonomy, BEHCNTRL = parental behavioral control, GLOBALCT = constructive thinking, HSVOL = hrs. spent volunteering in HS, LOGHLPG $=(\log$ of $)$ hrs. spent in informal helping.

Table 10

Multivariate Followup Contrasts for Significant Main Effect of Volunteer Work on 11 Variables, with Gender as a Covariate

\begin{tabular}{lcccc}
\hline & \multicolumn{5}{c}{ Wilks's } \\
Contrast & df & Lambda & Approx. F & Sig. of F \\
\hline Contrast \#1 & 11,346 & .946 & 1.796 & .053 \\
Contrast \#2 & 11,346 & .856 & 5.287 & .001 \\
\hline
\end{tabular}

Note. Contrast \#1: Effect of Volunteer Work for Volunteers of 1-2 Hours per Week vs. Nonvolunteers, Contrast \#2: Effect of Volunteer Work for Volunteers of 3 or More Hours per Week vs. Nonvolunteers. 


\section{Table 11}

Univariate F-tests for Follow-up Contrasts: Effect of Volunteer Work on 11 Variables with (1.356) df, with Gender as a Covariate

\begin{tabular}{|c|c|c|c|c|}
\hline \multirow[b]{2}{*}{ Variable } & \multicolumn{2}{|c|}{$\begin{array}{c}\text { Contrast \#1: Volunteers of 1-2 } \\
\text { Hrs.Mk. vs. Nonvolunteers }\end{array}$} & \multicolumn{2}{|c|}{$\begin{array}{l}\text { Contrast \#2: Volunteers of } 3+ \\
\text { Hrs. } \text { Wk. vs. Nonvolunteers }\end{array}$} \\
\hline & $\bar{E}$ & Sig. of $\mathrm{E}$ & $\bar{E}$ & Sig. of $\mathrm{F}$ \\
\hline EMPATHY & 1.91858 & .167 & 12.22721 & $.001^{\star \star}$ \\
\hline PERSDISS & 3.75967 & .053 & 3.06188 & .081 \\
\hline PERSPECT & 0.00724 & .932 & 1.38615 & .240 \\
\hline PERSRESP & 0.82642 & .364 & 11.57907 & $.001^{\star \star}$ \\
\hline MORLREAS & 1.25872 & .263 & 18.90125 & $.001^{\star *}$ \\
\hline LOGINVOL & 1.37832 & .241 & 8.44974 & $.004 * *$ \\
\hline PSYAUTON & 0.10008 & .752 & 2.62529 & .106 \\
\hline BEHCNTRL & 0.48468 & .487 & 0.55887 & .455 \\
\hline GLOBALCT & 1.66535 & 198 & 1.02634 & .312 \\
\hline HSVOL & 0.03487 & 852 & 16.40959 & $.001^{\star \star}$ \\
\hline LOGHLPG & 4.60551 & .033 & 12.66226 & $.001^{* *}$ \\
\hline
\end{tabular}

EMPATHY = empathic concern, PERSDISS $=$ personal distress, PERSPECT $=$ perspective taking ability, PERSRESP = personal/social responsibility, MORLREAS = moral reasoning style, LOGINVOL = (log of) parents' involvement/acceptance, PSYAUTON = parents' granting of psychological autonomy, BEHCNTRL = parental behavioral control, GLOBALCT = constructive thinking, HSVOL $=$ hrs. spent volunteering in HS, LOGHLPG $=(\log$ of $)$ hrs. spent in informal helping.

Table 11 shows that the variables empathy, personal responsibility, moral reasoning, (log of) parental involvement/acceptance, high school volunteerism, and (log of) informal helping discriminated nonvolunteers from altruistic volunteers who spend three or more hours per week in volunteer work $(\underline{p}<.01)$, but did not discriminate nonvolunteers from altruistic volunteers who spend only one or two hours per week in volunteer work.

Returning to the omnibus MANCOVA (Table 8), there was no significant effect for the interaction of Volunteer work with University. There was a significant main effect for University, Wilks's lambda $=.83$, approximate $\underline{F}(33$, 
$1020.08)=2.07, \underline{p}<.01$. Univariate follow-up tests indicated that only one variable, personal distress, was significantly different across universities, $\underline{E}(3$, $356)=4.13, \underline{p}<.01$. Examination of group means indicated that students at Universities \#1 and \#4 reported less personal distress during crisis situations (respective means, adjusted for gender, 2.13 and 2.15) than did students at Universities 2 and 3 (respective means, adjusted for gender, 2.35 and 2.33). Because the effect of university did not interact with the effect of volunteer work, differences between universities were not explored further.

Table 12 lists the means for the eleven dependent variables across the three levels of volunteer work, adjusted for gender. Altruistic volunteers who spent three or more hours per week in volunteer work reported significantly greater levels of empathy, personal responsibility, and moral reasoning than did nonvolunteers. In addition, they reported more time spent in community service volunteer work during high school and more time spent in informal helpfulness to neighbors and friends than did nonvolunteers. They also reported less parental involvement and acceptance than did nonvolunteers.

Pooled within-cells correlations for the eleven dependent variables revealed that three of the variables that were significantly related to volunteer work had intercorrelations greater than .30: empathy, personal responsibility, and moral reasoning (see Table 18 in Appendix E). Univariate F's for these three variables are therefore somewhat redundant (i.e., represent overlapping variances). Two follow-up stepdown analyses were conducted to assess the 
Table 12

Significant Differences Among Means for 11 Personality, Parenting, and Behavioral Variables Across 3 Levels of Volunteer Work $(N=369)$. Adjusted for Gender

\begin{tabular}{|c|c|c|c|}
\hline Variable & Nonvolunteers & $\begin{array}{c}\text { Altruistic } \\
\text { Volunteers } \\
\text { 1-2 Hr/Wk. }\end{array}$ & $\begin{array}{c}\text { Altruistic } \\
\text { Volunteers } 3+ \\
\text { Hrs.Mk. }\end{array}$ \\
\hline Empathy & 3.81 & 3.94 & $4.01^{\star \star}$ \\
\hline Personal Distress & 2.29 & 2.34 & 2.09 \\
\hline Perspective-Taking Ability & 3.72 & 3.68 & 3.79 \\
\hline Personal/Social Responsibility & 3.36 & 3.35 & $3.54 * \star$ \\
\hline Moral Reasoning & 3.62 & 3.81 & $3.87 \star$ \\
\hline (Log of) Parental Involvement/Acceptance & 0.18 & 0.20 & $0.24 * \star$ \\
\hline Parents' Granting of Psychological Autonomy & 3.19 & 3.06 & 3.07 \\
\hline Parental Behavioral Control & 5.62 & 5.76 & 5.62 \\
\hline Constructive Thinking & 3.42 & 3.49 & 3.39 \\
\hline High School Volunteer Work & 2.81 & 3.20 & $3.58^{\star \star}$ \\
\hline (Log of) Informal Helping & 0.13 & 0.12 & $0.21 \star$ \\
\hline
\end{tabular}

** Significantly different from Nonvolunteers, $\mathrm{p} \leq .01$

relative contributions of correlated variables (see Tables 9 and 13). Stepdown analysis assesses the significance of each variable after removing the effects of previously entered variables, and is only as meaningful as the theory that guides the ordering of the variables.

Order of entry of the variables in this stepdown analysis was based on Hoffman's theory of moral development $(1979,1981,1988)$, and on the fact that the focus of this study was personality variables rather than past behaviors. Thus, empathy (the infant's developmental basis of prosocial behavior according 
to Hoffman's theory) was entered first. Measures of prosocial emotions or cognitions that theoretically begin to develop during childhood were entered next (personal distress, perspective-taking, personal responsibility, and moral reasoning). Then, measures of parental behaviors during the subjects' high school years were entered (parental involvement/acceptance, parents' granting of psychological autonomy, and parents' control over subjects' behaviors). Next, a measure of higher-level cognitive processes was entered (constructive thinking). The two measures of recent altruistic behaviors (high school volunteerism and informal helpfulness) were entered last because the focus of this study was on personality characteristics rather than on behavioral predictors. It is important to note, however, that results of the stepdown analysis would have been different if the behavioral variables had been entered first.

Results of the stepdown analysis for the eleven dependent variables across all three levels of volunteer work (Table 9) indicated that empathy and (log of) parental involvement/acceptance, remained significant at the $\mathrm{p} \leq .01$ level. The other variables that had been univariately significant at the $\underline{p} \leq .01$ level were no longer significant at that level. The stepdown analysis that was performed following the significant contrast between nonvolunteers and altruistic volunteers of three or more hours per week is reported in Table 13.

The same two variables, empathy and (log of) parental involvement/acceptance, remained significant discriminators between altruistic volunteers and nonvolunteers. In addition, hours of high school volunteer work 
remained significant, Stepdown $\underline{E}(1,347)=7.28, \underline{p} \leq .01$. These results indicate that when the eleven variables are ordered according to Hoffman's theory of moral development, three variables (empathy, parental involvement/acceptance, and high school volunteer work) contribute the most unique variance to differences between altruistic college volunteers and nonvolunteers.

Table 13

Roy-Bargmann Stepdown F-tests for Follow-up Contrast \#2: Volunteers of 3+ Hrs.Mk. vs. Nonvolunteers, with Gender as a Covariate

\begin{tabular}{lrrcc}
\hline Variable & StepDown F & Hypoth. DF Error DF & Sig. of F \\
\hline EMPATHY & 7.76177 & 1 & 356 & $.006^{\star \star}$ \\
PERSDISS & 4.41146 & 1 & 355 & .036 \\
PERSPECT & 0.11744 & 1 & 354 & .732 \\
PERSRESP & 6.30069 & 1 & 353 & .013 \\
MORLREAS & 4.83842 & 1 & 352 & .028 \\
LOGINVOL & 12.19035 & 1 & 351 & .001 \\
PSY* & 0.91682 & 1 & 350 & .339 \\
BEHCNTRL & 1.09747 & 1 & 349 & .296 \\
GLOBALCT & 4.92529 & 1 & 348 & .027 \\
HSVOL & 7.27877 & 1 & 347 & .007 \\
LOGHLPG & 6.75596 & 1 & 346 & .010 \\
\hline
\end{tabular}

${ }^{\star \star} p \leq .01$

NOTE. Variables were entered in accordance with Hoffman's theory of moral development. EMPATHY = empathic concern, PERSDISS = personal distress, PERSPECT = perspectivetaking ability, PERSRESP = personal/social responsibility, MORLREAS $=$ moral reasoning style, LOGINVOL = (log of) parents' involvement/acceptance, PSYAUTON = parents' granting of psychological autonomy, BEHCNTRL = parental behavioral control, GLOBALCT = constructive thinking, HSVOL $=$ hrs. spent volunteering in HS, LOGHLPG $=(\log$ of $)$ hrs. spent in informal helping.

Comparisons of mean differences between groups, adjusted for the effect of gender, are reported in Table 12. Six variables discriminated altruistic volunteers who volunteered for three or more hours per week from 
nonvolunteers. The three variables that retained their unique variance in the stepdown analysis indicated that altruistic volunteers who spent three or more hours per week in volunteer work scored significantly higher on a measure of empathy than did nonvolunteers (respective means 4.01 vs. 3.81 ), reported that their parents were significantly less involved and accepting than did nonvolunteers (respective means .24 vs. .18 ), and reported significantly more hours of community service volunteer work during high school than did nonvolunteers (respective means 3.58 vs. 2.81 ). The scores for high school community service volunteer work on the original questionnaire were arranged as follows:

1. An average of about one hour per month or less

2. An average of about 2 to 4 hours per month

3. An average of about 5 to 7 hours per month

4. An average of about 8 to 10 hours per month

5. An average of over 10 hours per month

Thus, the most actively involved college volunteers reported, on average, having spent close to two hours per week in community service volunteer work during their high school years, while college nonvolunteers reported, on average, about one hour per week of volunteerism in high school.

\section{Additional Findings}

The hypotheses investigated in this study did not address gender differences among altruistic volunteers. However, in light of the significant relationship of gender to the dependent variables, additional follow-up analyses were conducted separately for men $(\underline{N}=141)$ and for women $(\underline{N}=228)$. 
Because these are post-hoc investigations, conclusions drawn from these analyses are viewed cautiously. Due to the smaller number of subjects in each analysis, volunteer work was collapsed to just two levels, altruistic volunteers vs. nonvolunteers, and a power analysis was computed for each MANOVA.

Results of a 2-way MANOVA for women $(\underline{\mathrm{N}}=228)$ are reported in Table 14. This MANOVA explored differences between female altruistic volunteers vs. nonvolunteers in the eleven dependent variables, across two levels of volunteer work (99 volunteers vs. 129 nonvolunteers) and four universities.

Results revealed no interaction between volunteer work and university, and no main effect for university. Observed power to detect differences at the .05 level of probability for these analyses was .98 and .99 respectively, which is well over the .80 figure recommended by Keppel (1991, p.75). There was a significant main effect for volunteer work among women, with Wilks's lambda = .85 , approximate $\mathrm{E}(11,210)=3.42, \mathrm{p} \leq .01$, and observed power of .99 at the .05 level. Follow-up univariate analyses revealed significant differences between volunteers and nonvolunteers on empathy, personal responsibility, moral reasoning, and high school volunteering. For each of these variables, female volunteers reported higher levels of the trait than did female nonvolunteers (see Appendix E).

- The 2-way MANOVA for men $(\underline{N}=141)$ is reported in Table 14. This MANOVA also explored differences in the eleven variables across two levels of volunteer work (73 volunteers vs. 68 nonvolunteers) and four universities. 
Table 14

Follow-up Univariate F-tests for Effect of Volunteer Work (2 levels) on 11 Variables for 228 Women and for 141 Men

\begin{tabular}{|c|c|c|c|c|}
\hline \multirow[b]{2}{*}{ Variable } & \multicolumn{2}{|c|}{ Women, with $(1,220)$ D.F. } & \multicolumn{2}{|c|}{ Men, with $(1,133)$ D.F. } \\
\hline & $F$ & Sig. of $F$ & $F$ & Sig. of $F$ \\
\hline EMPATHY & 12.93385 & 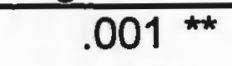 & 2.54021 & .113 \\
\hline PERSDISS & 0.17887 & .673 & 0.29782 & .586 \\
\hline PERSPECT & 0.17111 & .680 & 1.19918 & .275 \\
\hline PERSRESP & 8.89683 & $.003^{\star \star}$ & 0.13826 & .711 \\
\hline MORLREAS & 15.61950 & $.001 \star \star$ & 4.48774 & .036 * \\
\hline LOGINVOL & 1.29255 & .257 & 3.37668 & .068 \\
\hline PSYAUTON & 0.00094 & .976 & 4.93870 & .028 * \\
\hline BEHCNTRL & 0.41069 & .522 & 1.63196 & .204 \\
\hline GLOBALCT & 0.03956 & .843 & 0.56824 & .452 \\
\hline HSVOL & 13.20629 & $.001 \star \star$ & 1.98601 & .161 \\
\hline LOGHLPG & 0.48083 & .489 & 6.28064 & $.013^{*}$ \\
\hline
\end{tabular}

Results of omnibus MANOVA for Women: $F(11,210)=3.42128, p \leq .01$.

Results of omnibus MANOVA for Men: $E(1 \overline{1}, 123)=1.46394, \mathrm{p}=.154$.

EMPATHY = empathic concern, PERSDISS = personal distress, PERSPECT = perspectivetaking ability, PERSRESP = personal/social responsibility, MORLREAS = moral reasoning style, LOGINVOL = (log of) parents' involvement/acceptance, PSYAUTON = parents' granting of psychological autonomy, BEHCNTRL = parental behavioral control, GLOBALCT = constructive thinking, HSVOL = hrs. spent volunteering in HS, LOGHLPG $=(\log$ of $)$ hrs. spent in informal helping.

Results revealed no interaction between volunteer work and university, Wilks's lambda $=.70$, approximate $\mathrm{F}(33,363.08)=1.40, \underline{\mathrm{p}} \leq .05$, with observed power of .98 to detect differences at the .05 level. There was a significant main effect for university, Wilks's lambda $=.69$, approximate $\underline{E}(33,363.08)=1.49, p$ $\leq .05$, with observed power of .99 to detect differences at the .05 level. There were, however, no significant differences among universities in univariate followup tests for each of the eleven variables, so no further comparisons among universities were made. 
There was no main effect for volunteer work among men. Observed power for this analysis was .74 at the .05 level, which is slightly below the optimum level of .80 recommended by Keppel (1991). In light of this, it is not clear whether lack of significant differences between male volunteers and nonvolunteers in this study is an accurate conclusion, or is due to insufficient power. Ordinarily, lack of significant differences between groups in the omnibus MANOVA precludes separate univariate follow-up analyses for each of the dependent variables. However, because of the possibility that the insignificant omnibus MANOVA result might be due to insufficient power, follow-up univariate analyses were conducted for the eleven variables, with the understanding that results of these post-hoc analyses were for exploratory purposes only.

None of the univariate follow-up analyses for the effect of volunteer work for men was significant at the $\underline{\underline{p}} \leq .01$ level. Three variables were significant at the $\underline{\mathrm{p}} \leq .05$ level: (log of) informal helping, parental psychological autonomy, and moral reasoning. Only one of these variables (moral reasoning) was a significant discriminator between female altruistic volunteers and nonvolunteers, and only two, moral reasoning and (log of) informal helping, were significant discriminators between altruistic volunteers and nonvolunteers in the overall analysis for men and women. It is important to remember that because eleven follow-up univariate tests were performed, three variables significant at the level of $\mathrm{Q} \leq .05$ merely suggest hypotheses for future studies, and should not necessarily be interpreted as positive findings. 


\section{Summary}

In summary, six of the original eleven variables were significantly different across three levels of volunteer work for the sample of 369 men and women selected for the main analyses. The significant variables were: empathic concern, personal responsibility, moral reasoning, (log of) parental involvement/acceptance, high school volunteerism, and (log of) informal helping. Follow-up contrasts indicated that differences between volunteers and nonvolunteers appeared only for volunteers who spent three or more hours per week in aitruistic volunteer work. There were no significant differences on any of the eleven variables between nonvolunteers and altruistic volunteers who volunteered for only 1-2 hours per week. Stepdown analyses based on the developmental sequence of Hoffman's theory of moral development suggest that the most significant contributors to college volunteerism were higher levels of empathy, more time spent in high school volunteerism, and lack of parental involvement/acceptance during adolescence.

Separate analyses for men and women indicated that four variables discriminated female altruistic volunteers from female nonvolunteers: empathy, personal responsibility, moral reasoning, and high school volunteering. There were no significant differences between male altruistic volunteers vs. nonvolunteers on the omnibus MANOVA for any of the eleven variables. Exploratory post-hoc analyses at the $\underline{\mathrm{p}} \leq .05$ level suggested the possibility that male altruistic volunteers differed from male nonvolunteers on three of the 
eleven variables. Only one of these three variables (moral reasoning) was a significant discriminator between female altruistic volunteers and nonvolunteers, suggesting that there may be different patterns of personality and past experience for altruistic male vs. altruistic female college volunteers. It is important to note, however, that because of the small number of male subjects in the analysis, the relatively large number of dependent variables, and the fact that significance for males was only attained at the $\mathrm{p} \leq .05$ level (rather than the more rigorous $\underline{\mathrm{p}} \leq .01$ level), interpretation of results of the post-hoc analyses for men are speculative, and are meant only to suggest hypotheses that might be tested in future research. 


\section{Chapter V}

Discussion

Prosocial Personality Variables: Empathy, Personal Responsibility, and Moral Reasoning

Results of this study support the hypothesis that altruism in college students is related to three prosocial personality variables: empathic concern, personal responsibility, and moral reasoning. The relationship of altruism with higher levels of empathic concern supports similar findings in studies of college students and adults reported by Batson, et al. (1988, 1989, 1991), Eisenberg, Fabes, et al. (1989), Eisenberg, Miller, et al. (1989), Oliner and Oliner (1988), Stiff et al (1988), and early childhood studies by Radke-Yarrow and ZahnWaxler (1984), Zahn-Waxler and Radke-Yarrow (1982), and Zahn-Waxler et al. (1992). The current finding that, in stepdown analysis, the relationship of altruism with empathic concern was stronger than the relationship of altruism with personal responsibility and with moral reasoning lends support to Hoffman's contention $(1981,1988)$ that empathy may be the developmental foundation for adult altruistic behavior.

The absence of a relationship between altruistic volunteerism in college students and personal distress differs from results described by Batson et al. $(1988,1989)$ and by Penner (1993), who both found a negative relationship between altruism and personal distress. There are a number of potential explanations for the different findings. 
1) Although the current study used Penner's measure of personal distress on a similar population, scores were analyzed differently. Penner's studies combined scores for personal distress, empathic concern, personal responsibility, moral reasoning style, and perspective-taking ability into one measure, and his results are reported in terms of altruism's relationship with the composite (factor scores) for these variables in combination. The personal distress subscale had a factor loading of -.55 on Penner's Helpfulness factor. The current study analyzed separately the effects of each subscale (each of. which was drawn from a previously-validated measure for each trait; see Methods section), with the result that not all subscales contributed to differences between altruistic college volunteers and nonvolunteers. Thus, it is possible for Penner to report a relationship between altruism and personal distress (and between altruism and perspective-taking ability), while the current study does not, even though the same measures were used.

2) The current study found that belonging to an organization, in and of itself, was negatively related to personal distress. Members of nonaltruistic organizations reported less personal distress than did subjects who were not members of any organization. By eliminating this confound from the current study (i.e., by comparing altruistic volunteers only with members of non-altruistic organizations), the effect of organization membership per se was removed. Comparable precautions were not taken in Penner's study comparing 61 members of a hurricane rescue volunteer organization with 51 nonvolunteers. 
Thus some of the differences in personal distress found by Penner could simply be due to the effect of organization membership.

3) Batson's measure of altruism (and Penner's measure in one of his studies) was subjects' individual responses to a personal appeal for help. In contrast, the measure of altruism in the current study was sustained altruistic volunteer work, performed in the context of an established organization. Batson's and Penner's criteria thus required a personal response to an immediate emergency, while the current study tapped a tendency to assist others in a more planned manner. Hoffman hypothesized that excessive personal distress will lead an otherwise empathic person to avoid someone in crisis (Hoffman, 1979). The current study does not necessarily conflict with Hoffman's theory. Rather, it raises the possibility that organized volunteer work is a vehicle by which empathic persons might help others without arousing personal distress.

The variable "perspective-taking ability" was included in this study as part of the Prosocial Personal Battery. Although it is not a direct measure of empathy, theorists (e.g., Piaget, 1965) have suggested that perspective-taking ability is a developmental prerequisite for altruistic or prosocial responses.

Perspective-taking ability in the current study was related to personal responsibility, empathic concern, and informal helpfulness, but not to organized altruistic volunteerism (see Table 5). The lack of relationship between perspective-taking ability and altruism in this study suggests that perspective 
taking ability may be necessary but not sufficient for altruistic behavior to occur. In other words, one may be skilled at viewing situations from another person's perspective without necessarily acting altruistically toward that person. As Feshbach (1979) points out, sociopaths may use their perspective-taking abilities to manipulate others with the intent to exploit, rather than help. Perspective-taking ability should therefore be carefully distinguished from empathy.

The relationship of altruism with a strong tendency to accept personal responsibility for one's actions supports similar findings in studies of adults and college students reported by Eisenberg et al. (1989), Monroe (1991), Monroe and Epperson (1994), Oliner and Oliner (1988), and Schwartz (1968). In addition, the current finding that empathic concern and personal responsibility are jointly related to altruism supports Chapman, et al.'s (1987) study of children, in which the investigators concluded that "... it may not be merely a tendency to feel the same affects as the other person...that motivates helping, but a disposition to feel a responsibility toward the other person's well-being" (p.145).

The relationship of altruism with use of mutuality-based and other-oriented moral reasoning (as opposed to self-centered reasoning) when making interpersonal decisions supports findings by Colby and Damon (1992), Hart and Fegley (in press), Oliner \& Oliner (1988), and Schwartz and Howard (1984). It is perhaps worth noting that in these studies, as in the current study, moral reasoning was assessed via self-report of reasoning process related to subjects' 
ordinary, day-to-day behaviors, rather than via questions about hypothetical moral dilemmas involving a fictional character. Studies of moral reasoning that have used Kohlberg-type hypothetical dilemmas have yielded a "generally positive" relationship between moral reasoning and moral behavior (as reviewed by Eisenberg and Mussen, 1989), but correlations were typically modest. Perhaps a distinction needs to be made in the literature between measures of practical moral reasoning such as the one used in the current study, and cognitive-developmental level of moral judgment assessed via hypothetical moral dilemmas. One recent study (Hart and Fegley, in press) did make such a distinction. The authors reported that exceptional commitment to community service among inner city adolescents was related to a moral dimension of selfconcept, but not to scores on Colby \& Kohlberg's Moral Judgment Interview, (1987).

Another measurement issue worth noting is that the moral reasoning questions in the current study tapped respondents' tendency to use both the ethic of care and the ethic of justice in decision-making. A strong tendency for altruistic volunteers to use only one or the other of these two modes of moral reasoning would have resulted in lower scores that would not have distinguished them from nonvolunteers. The relationship between the practical moral reasoning items on the Prosocial Personality Battery with altruism in this study thus supports merging Kohlberg's (Kohlberg \& Ryncarz, 1990) and Gilligan's 
(1982) theories of moral development, rather than arguing about the supremacy of one theory over the other.

Although the current results support a relationship between moral reasoning style and altruistic behavior, they do not indicate the direction of causality for this relationship. However, empirical support for the hypothesis that engaging in volunteer work can raise one's level of moral reasoning can be found in Boss's (1991) study of 71 college students enrolled in two nearly identical ethics classes. One class was required to perform twenty hours of community service volunteer work and keep a journal, in addition to the standard readings, lecture, and discussion. The other class was taught by the same instructor without the volunteer work requirement. College students in the class that required volunteer work experienced significantly higher gains in level of moral development (based on score on Rest's Defining Issues Test, 1979) than did students in the class that did not require volunteer work. This suggests that volunteer experiences can affect moral reasoning level when combined with sharing and discussion of experiences.

\section{Constructive Thinking}

The current study yielded no relationship between constructive thinking and altruistic volunteer work. This stands in contrast to reports of "certainty" (being sure one is doing the right thing) and "positivity" (sense of self-efficacy, resiliency, and resolve in the face of opposition or setbacks) reported for adult altruists and moral exemplars by Colby and Damon (1992), Monroe (1991), and 
Oliner and Oliner (1988), and relationships between competence and prosocial behaviors in children (Midlarsky, 1984).

In the search for possible reasons for this difference, the reliability and validity of the measure was reviewed. As described in the Method section, the Constructive Thinking Inventory (CTI) was developed and normed on 1,500 college students. Cronbach's alpha reliability estimates reported by Epstein \& Meier (1989) and replicated in the current study were both .90. In addition, Epstein and Meier (1989) and Katz and Epstein (1991) found positive relationships for the CTI with social/emotional success and negative relationships with psychological problems. Thus, the measure appears to have reasonably good reliability and some degree of construct validity. The question that remains, however, is whether the construct tapped by the CTI is the same construct that was found in the above-mentioned studies of altruists.

Possibly, constructive thinking as measured by the CTI was more a measure of overall self-esteem than of the type of positivity that Colby and Damon (1992) or Monroe (1991) described. The qualities typical of adult altruists and moral exemplars appeared to be more related to faith in a higher power and/or to moral righteousness than to faith in one's own ego. They aspired to success and accomplishment on behalf of others, not for themselves. The adult altruists and moral exemplars that were studied were not necessarily successful in their personal lives; in fact, many were not financially successful and/or experienced poor health. 
Oliner \& Oliner (1988) reported that self esteem per se was not a discriminating variable for Holocaust rescuers vs. bystanders:

"...The absence of a connection between self-esteem and altruism should not be surprising. People who are sufficiently content with themselves might feel freer to attend to others' needs, but because of their high self-image, might also regard themselves as appropriate recipients of...care from others, rather than bestowers. Alternately, people who think ill of themselves can become so obsessed by their own distress that they barely register anothers' needs; however, they can just as easily respond to others' needs as a way of enhancing their own self-image" (pp. 178-179).

In lieu of high self-esteem, the Oliners found greater internal locus of control (on Rotter's Internal-External Locus of Control scale) and greater attachment to people among rescuers than bystanders. In a study comparing the CTI with other, established measures of personality, Epstein and Meier (1989) reported that the CTI was more closely related to criteria of success in living than was Rotter's Internal-External Locus of Control scale. In addition, the CTI questions appear to award higher scores for lower levels of attachment to (or dependence on) other people. Thus, it is unclear whether the CTI captures the same qualities reported in studies of adult altruists.

The altruists studied by Monroe (1991), and by Colby and Damon (1992) were all adults whose altruism also required a good deal of leadership skill. It is also possible that 1) joining an existing campus-based altruistic organization requires less constructive thinking and less leadership ability than other, more independent, forms of altruism, and/or 2) these skills are not as clearly measurable in a college-age population. In addition, although competence may 
be related to younger children's helping, competence alone did not predict adolescent helping (Midlarsky \& Hannah, 1985). Helping in adolescents was inhibited by fear of disapproval and/or sensitivity to the possible embarrassment felt by potential recipients.

\section{Parenting Variables}

This study supports the hypothesis that altruistic volunteerism in college students is related to one of the three parenting practices discussed in the hypotheses, specifically parental involvement and acceptance. However, the direction of the relationship that was found (i.e., that college altruistic volunteers reported less parental acceptance and involvement than did nonvolunteers) was a surprise. Although directionality was not specified in the original hypothesis, the literature supports the assumption that the relationship between altruism and parental involvement/acceptance should be in the positive direction (Baumrind, 1989, 1991a, 1991b; Baumrind \& Black, 1967; Clary \& Miller, 1986; Colby \& Damon, 1992; Oliner \& Oliner, 1988; Rosenhan, 1970, 1972).

The negative relationship between altruistic volunteer work and parental involvement/acceptance, as well as the lack of relationship between altruistic volunteerism and parental willingness to grant psychological autonomy, and between altruistic volunteerism and parents' behavioral control, could be a function of the measures and population studied. Cronbach's alphas for the Authoritative Parenting Index in the current study were .80 for Parental Involvement/Acceptance, .75 for Behavioral Control, and .77 for Psychological 
Autonomy-Granting. These results are comparable to the reliability estimates reported by the original authors for a sample of over 6,000 high school students; they may have been adequate for research with a very large sample but problematic with a smaller sample. In addition, the Authoritative Parenting Index was originally developed on a broad range of high school students across the country, and was designed to predict high school achievement, which it did well. The variability measured by the questions is most likely reduced when applied to a smaller, more restricted sample of college students who have already achieved academic success, and whose scores were therefore likely to be skewed to the positive end of the normal curve. In addition, although the negative relationship between volunteer work and parental involvement/acceptance was statistically significant, the correlation between parental acceptance/involvement and volunteer work across all 469 subjects was only -.11 (see Table 5), and thus accounted for only about $1 \%$ of the variance between altruistic volunteers and nonvolunteers.

In addition to concerns about the psychometric properties of the current instrument, there could be a question about its validity, or its usefulness for measuring the type of acceptance (i.e., empathy) that is reportedly related to adult altruism. Although the Authoritative Parenting Index was designed with Baumrind's theory in mind, this brief series of questions could not by themselves replicate the entire range of Baumrind's intensive observations of children and parents. In addition, the current study asked only about parents' behaviors 
during subjects' last two years of high school. There were no questions about early childhood parenting practices or about subjects' reactions to, or feelings about, their parents' behaviors. In contrast, the studies by Rosenhan (1970), Oliner and Oliner (1988), and Colby and Damon (1992) emphasized altruists' feelings of respect, fondness, love, or attachment for their parents, rather than specific details of parental behavior. It would have been helpful to know whether subjects in the current study perceived their parents' involvement/acceptance, or lack thereof, to be motivated by concern for their development or by rejection.

The above reflections suggest that the negative correlation between parental involvement/acceptance and college volunteering may be an artifact of the instrument and/or of the population upon which it was used. On the other hand, although the instrument clearly had limitations, a review of the literature and of existing measures found few alternatives. This instrument was chosen as the best available option. The fact that the Behavioral Control subscale was related to gender (as one would expect), and that the three subscales of the measure were significantly intercorrelated, raises the possibility that results based on the Parental Involvement/Acceptance subscale may in fact be valid.

A possible explanation for the negative relationship between parental involvement/acceptance and college volunteerism may be that adolescents who do not receive sufficient nurturance at home might be more inclined to turn elsewhere for such social support. In fact, the literature on resilient youngsters indicates that a key factor in resiliency is the formation of "mentoring" 
relationships with adults outside one's family (Werner \& Smith, 1992). College students who were recipients of strangers' help, support, or mentorship as youngsters, might be more inclined to "give back" to society by becoming volunteers themselves. A gap in the current study's questionnaire was the lack of questions about the subjects' experiences as the recipient of help from strangers. In The Kindness of Strangers, Marc Freedman (1994) reviews adults' motivations for becoming volunteer mentors. Although the data for Freedman's book are primarily anecdotal, and thus suggestive rather than definitive, it may be worth noting that the concept of "connectedness" occurs frequently as a motivator for adult volunteerism. Could it be that adolescents who feel disconnected from their families might be more inclined to find "connectedness" in volunteerism?

In addition, organized volunteer experiences tend to be rewarding. The volunteer is most often accepted with warmth and appreciation--certainly by the director of the volunteer organization and often by the recipient of help. It is not difficult to construct a behavioral explanation for the development of volunteer work in adolescents who may feel misunderstood and undervalued at home. Such a scenario might involve reinforcing successive approximations to volunteerism by organization leaders and/or empathic peers, and could explain a relationship between more intense levels of volunteerism and lack of parental involvement/acceptance during adolescence. 
Finally, there is some indication in the literature that not all prosocial behavior stems from parental support. The study by Grusec (1991), cited earlier, found that four-year-olds whose prosocial behavior was most frequently followed by no parental response tended to be most prosocial. In addition, many of Rosenhan's (1970) "Partially Committed" freedom riders reported "...relationships with the socializing parent as downright hostile during their formative years and at best, cool and avoidant during the time they were interviewed," (p.262). The Partially Committed freedom riders' negative, or ambivalent, parent-child relationships contrasted starkly with the "positive, cordial, warm, and respecting" relationships typical of "Fully Committed" freedom riders. The attitude expressed in Rosenhan's study is that only the "Fully Committed" freedom riders exhibited true altruism, since they continued to engage in costly civil rights activities for over a year, while the "Partially Committed" engaged in only one or two freedom rides. However, one should not lose sight of the fact that, in the 1960's, any involvement in freedom rides involved risk and self-sacrifice, and that most people did not get involved at all. Rosenhan surmised that "...the entire involvement of the Partially Committed was inextricably bound to their search for value and their desire to define themselves as valuing people," (p.267). In contrast to his sample of Fully Committed freedom riders, these seekers appeared self-centered in their "altruism"; however, when seen in perspective against the rest of the (uninvolved) population, their active search for a moral dimension to their self- 
identity might be construed as a positive, rather than negative, striving.

Psychologists might rather ask what factors led Rosenhan's Partially Committed freedom riders to search for their identity in altruistic activities rather than through material success, addictive behaviors, or antisocial activities.

The negative relationship between parental involvement/acceptance and college volunteerism in the current study raises the possibility that the typical college volunteer may be more similar to Rosenhan's "Partially Committed" freedom riders than to Colby and Damon's (1992) moral exemplars, or to Hart and Fegley's (in press) adolescent care exemplars, or to the Holocaust rescuers interviewed by the Oliners' (1988) or by Monroe and Epperson (1994). The criteria for "altruism" in the current study were far less stringent, and less costly, than the criteria in these other studies. Altruists in the other studies indicated that involvement with altruistic activities was central to their self-concept, and stemmed from warm relationships with parents who modeled morally exemplary attitudes and behaviors. The college volunteers in the current study may or may not have shared these qualities. It is entirely possible that a great number of them engage in college volunteerism in an attempt to find out who they are in relation to others, rather than as an expression of an already-solid identity. From the perspective of the psychologist/educator, it is important to find out what eventually becomes of such "Partially Committed" young adults. Can certain life experiences, or educational experiences, replace the lack of parental altruistic 
role models? What factors help or hinder young adults with less involved/accepting parents to define their moral identity?

\section{Additional Findings}

Organizational status. Belonging to an organization per se was related to lower levels of personal distress and to higher levels of parental behavioral control. This finding suggests that organizational status should be controlled in studies of organized volunteer work.

Behavioral variables. Although the initial hypotheses of this study did not address past behaviors as predictors of college altruistic volunteerism, hours of community service volunteering in high school and current level of general helpfulness to friends and neighbors were included in the main analyses due to their strong correlations with altruistic volunteer work in preliminary analyses. The finding that both were significant predictors of altruistic volunteer work, and in particular, that high school volunteering retained its significance in stepdown analysis even after the effect of all of the personality and parenting variables were taken into account, should come as no surprise to experimental psychologists who hold to the belief that "the best predictor of future behavior is past behavior." The current finding, however, does not answer the question of whether high school volunteerism "causes" college volunteering, or whether both are a result of a third variable, such as personality or parenting factors.

Although the current study could not directly assess causality, some precautions were taken that may shed some light on the issue. For example, for 
college volunteer work, subjects were instructed to only include volunteer hours for which they received neither pay nor course credit or other remuneration. Unpaid hours spent in organizations that might benefit the student (e.g., sports, band, student government, theater, newspaper) were recorded under categories other than "altruistic volunteer work." For high school volunteer work, on the other hand, subjects were instructed to include all types of community service, including fulfillment of church, scouts, or other requirements, provided they received no financial remuneration for their work. This could include community service work done to impress college admissions officers. One would expect that at least some high school students were motivated only by some form of "credit" for their community service, and that these students might, thus, stop volunteering once they were admitted to college or were no longer members of their local organizations. The fact that the relationship was strong between the more general forms of high school community service and the more rigorous category of college altruistic volunteer work suggests (though it does not prove) that high school volunteerism may help students establish a pattern, or norm, of volunteerism that can carry over into their college years. As described earlier, a scenario for a behavioral explanation for the development of a "habit" of volunteer work among adolescents is not difficult to imagine. In addition, evidence that actual volunteer experience helped increase college students' level of moral reasoning (Boss, 1991) raises the possibility that prior volunteer 
experiences may predispose subjects to increased volunteerism via raising their level of moral reasoning.

Relevance of gender. Post-hoc analyses for men and women separately suggested significant differences in personality and past experiences between male and female altruistic college volunteers. Four variables distinguished female altruistic volunteers from nonvolunteers: empathic concern, personal responsibility, moral reasoning, and high school volunteering. In contrast, there was no significant overall difference between male volunteers vs. nonvolunteers. Because of the relatively small number of men, results are inconclusive, and there exists the possibility that some of the variables that were investigated do discriminate male altruistic volunteers from nonvolunteers; however, these variables do not appear to be the same variables that distinguished female altruistic volunteers from nonvolunteers. Results of the current post-hoc analyses suggest further investigation of possible differences in the profiles of male vs. female altruistic volunteers.

\section{Summary}

In summary, college altruistic volunteers differed from nonvolunteers on the combination of prosocial personality variables empathy, personal responsibility, and moral reasoning. In addition, they reported relatively less parental involvement and acceptance during adolescence and relatively higher levels of community service volunteerism during high school, along with a tendency to engage in more informal helping. These distinctions became clearest when 
comparing nonvolunteers with students who volunteered for at least three hours per week. There appeared to be differences among male and female altruistic volunteers, which should be studied further.

Although the combination of prosocial, parenting, and behavioral variables was sufficient to discriminate between volunteers and nonvolunteers, it accounted for only about $19 \%$ of the variance, and could not address the question of causality.

\section{Critique}

This cross-sectional study shares all the limitations typical of quasiexperimental, non-longitudinal designs. That is, results are only correlational and give no indication of causality or of the developmental sequence of relationship among variables. In addition, the amount of variance in volunteer work that was accounted for by the combination of the eleven variables, although statistically significant, was under $20 \%$. In other words, over $80 \%$ of the variability between altruistic college volunteers and nonvolunteers remains unaccounted-for by the variables investigated in this study. This is a humbling statistic for any investigator.

A further limitation of this study is related to the measures used. Selfreports of activities and personality tendencies are subject to limitations in reliability and validity. Internal consistency reliability estimates for the subscales ranged from .65 to .90 (with most around .75), indicating a good deal of error variance. Self-reports may be subject to both intentional and unintentional 
distortion. There was no "lie scale" or other method to measure subjects' tendency to respond based on social desirability of answers. In addition, although all personality/parenting scales had been drawn from previous research, the external validity demonstrated by these measures (relationship to the constructs that they supposedly measure) was not assured. In particular, the measure of parenting practices was designed and refined (via factor analysis) to predict academic success, not pro-social behavior; aspects of parenting related to prosocial behavior that were not also strongly predictive of academic success would thus have been eliminated. This measure was, furthermore, developed on a large high school population that included the normal range of successful and unsuccessful students. Its ability to predict outcomes would thus be seriously limited when applied to a restricted sample of college students who, by definition, fall almost exclusively at the upper end of the normal distribution for high school academic success.

An additional caveat in interpreting results of this study is that it investigated only one aspect of altruism (organized volunteer work), in only one population (college students). There is much debate in the literature regarding the proper definition of "altruism" and whether such a phenomenon even exists (c.f., Batson, 1991, Rushton, 1984). College volunteerism often affords tangible rewards that could, by some definitions, disqualify it from consideration as "altruism" despite its cost to the volunteers. For example, volunteer experiences may help college students get better jobs, or could provide satisfying social 
interactions. It can also be argued that the cost of volunteerism is relatively low for college students, who have few other serious obligations. This study did not address these objections. It also did not address the question of who helps in emergency rescue situations, and it only briefly touched on the type of selflessness that individuals exhibit when they take on informal obligations to others (e.g., watching out for an elderly neighbor, housing a homeless person, or taking in one's abandoned nephews).

The parenting measures that were used in this study did not, in retrospect, appear to capture the constructs that were most likely significant for the development of altruistic behaviors in children. Baumrind's authoritative parenting style has been related to social competence in observational studies of parents and adolescents. The 26-question self-report survey used in this study cannot begin to duplicate Baumrind's work. In addition, it can be argued that although the components of social competence studied by Baumrind are similar to those of altruism (e.g., greater empathy and responsibility in children of authoritative parents than in children of other types of parents), the level of social competence that was significant in Baumrind's work does not, in and of itself, constitute altruism; this level of social competence may be a necessary, but not sufficient, condition for the manifestation of altruistic volunteer work. In addition, the survey that was used in the current study did not address subjects' feeling of closeness to their parents (an important variable for adolescents according to Baumrind, 1991a), or their perceptions of their parents as role 
models of empathy or altruism (significantly related to altruism in the literature review). In fact, the question of role models for altruism (whether in parents, grandparents, or other significant adults, such as teachers or mentors) was not addressed in this study.

Another interesting facet of altruistic motivation that was not assessed in the current study was subjects' perceptions of their relationship to "all humankind." Monroe $(1991,1994)$ maintains that altruists share a distinctive cognitive schema, in which they perceive themselves as "...one with all mankind (sic)," and which distinguishes them from nonaltruists. An outstanding quality that typically surfaced in interviews with rescuers by Monroe $(1991,1994)$ and Oliner and Oliner (1988) was the altruists' conviction that they had no choice but to help, because of their intense connectedness to all of humanity. The Ascription of Responsibility scale and the Empathic Concern scale somewhat addressed this quality, but these instruments fall short of measuring the sense of universality that was described in the interviews.

\section{Suggestions for Future Research}

A number of suggestions have already been made regarding directions for further study of differences between altruistic volunteers and nonvolunteers. One such suggestion involved the use of more reliable, valid, and comprehensive measures of parenting variables. In particular, a measure of subjective attachment to parents (e.g., perceptions of emotional closeness) may be more useful than questions involving recall of parental behaviors. In addition, 
questions about subjects' perceptions of their parents as role models and of the presence of role models for altruism among other significant adults would be helpful. Questions about family functioning, family cohesiveness, and experience as the recipient of aid from non-family sources may also prove useful in investigating why altruism in the current study appeared higher among subjects with less supportive parents. Information about families' socioeconomic, community, religious, and cultural expectations for volunteerism might also account for some portion of the variance.

The inclusion of questions about past volunteer experiences was a minor aspect of the current study. It is recommended that future investigators ask for more detail about high school volunteer experiences and about the influence of high school experiences on subjects' choices of extracurricular college activities.

Inclusion of a social desirability scale would be useful to rule out the possibility that subjects' responses are attributable their desire to appear socially or politically correct. In addition, a measure of one's conception of one's relationship to "all humankind"--the aspect of cognitive schema that consistently appeared significant in qualitative studies of altruists--is worth developing. In reviewing the literature, no such scale was found.

In light of the fact that the variables in this investigation accounted for only about 19 percent of the variance in volunteerism, a qualitative approach, including interviews and focus groups, might help formulate clearer hypotheses and identify a better set of variables for future quantitative studies. It might 
prove fruitful to investigate both differences and similarities between belonging to a social, sports, or other organization, and belonging to an altruistic volunteer organization.

Finally, to adequately address questions about the development of altruism under different conditions of parenting and life experiences, large-scale longitudinal studies are ultimately needed. Before such studies are undertaken, however, it is important to develop reliable, valid measures that tap the constructs most likely to be relevant for the development of altruism at different points across the lifespan. To accomplish this goal, shorter-term studies of altruism at various developmental stages could be designed with the potential for two to three-year follow-up.

\section{Implications for School Psychology Practice}

The study of altruism has a number of implications for school psychology. Educators have long been concerned with ways to reduce conflict and foster cooperation among children. Recent increases in violent crimes, drug abuse, and suicide among children and adolescents have prompted parents, educators, and psychologists to search for more effective ways to stem the tide of childhood antisocial behavior (Damon, 1988). The incidence of antisocial behavior in childhood has long-lasting consequences for society. Antisocial behaviors that originate in childhood frequently persist into adulthood (Krebs \& Miller, 1985). Few studies, however, have documented the development and persistence of 
prosocial behaviors from childhood through adulthood (Eisenberg, 1988; Krebs \& Miller, 1985).

In the school psychology literature, children's prosocial behaviors have frequently been addressed in terms of discrete social skills (Gresham \& Elliott, 1989). Remedial programs have most often focused on behavioral interventions (e.g., Dodge, 1985, Gresham, 1990), with little attention paid to the potential role of prosocial emotions. This is understandable, since children's behaviors are more amenable to identification, quantification, and reinforcement than are their emotions. However, prosocial emotions may be useful even in a behavioral approach, for their role as competing responses to antisocial impulses. In other words, prosocial feelings of concern or empathy for others may be incompatible with aggression toward them. Eisenberg and Miller's (1988) meta-analysis of empirical studies supports this hypothesis. Studies of empathy training for elementary-school children by Feshbach and Feshbach $(1982,1983)$ are particularly relevant. Both highly-aggressive and average-aggressive children in their empathy training groups increased in prosocial action, while children in control groups did not. In a review of the literature, Feshbach (1979) also found "...a consistent inverse relationship between empathy and aggression."

The review of the literature cited earlier included a number of qualitative studies that emphasized the presence of role models, empathy, and moral intentions in the development of a "cognitive schema" of oneself related to all humankind. The documented existence of altruists such as Carnegie heros and 
Holocaust rescuers, who risked their lives repeatedly to help strangers, contrasts with sociobiologists' claims that altruism is a biologically-based phenomenon restricted to helping one's genetic relations (c.f., Wilson, 1975). A recent study by Burstein, Crandall, and Kitayama (1994) claims to support the sociobiological perspective by demonstrating that college students' decisions of whom to rescue in hypothetical life-and-death situations follow the biological pattern of helping close kin over more distant relatives or strangers. However, the authors also found that subjects tended to perceive step-siblings and step-parents as relatives. This finding suggests that our choice of whom we help in a crisis may be mediated by our perceptions of familial relatedness, and may thus be amenable to shaping via childrearing practices and educational experiences,.

The results of the current study, together with the existing body of literature on altruism and prosocial behavior, suggest some practices that might be implemented within a school setting to increase the likelihood of prosocial behavior, decrease insensitivity and aggression, and influence students to become helpers rather than bystanders. Like any hypotheses, however, the effects of these interventions should be assessed empirically, rather than taken for granted on the basis of the literature.

Recommendations. Elementary and high schools should be encouraged to develop community service programs that provide supervised opportunities for younger students to volunteer. At the high school level, these programs might carry course credit in order to encourage widespread participation. Students 
with less involved, less supportive parents might be especially encouraged to participate.

Programs to develop prosocial behaviors should include emotional as well as behavioral components. In particular, the ability to see things from someone else's perspective should not be taught in isolation, as a cognitive skill, but rather in conjunction with empathy training. Adult and peer models of helping, sharing, and caring should be readily available. In other words, teachers, administrators, and school volunteers must actively demonstrate genuine caring for all children in the school. Administrators and teachers should strive to communicate a sense of "extended family" in the school and community. Social responsibility and informal helpfulness to one's peers should be modeled and encouraged as normative, expected, behaviors.

Younger children should be taught specific helping skills, to enhance their self-perceptions of competence. Adolescents should be encouraged to overcome feelings of self-consciousness, or fear of disapproval, regarding being the first to offer help. Discussions and demonstrations of practical applications of the ethic of care and the ethic of justice can be woven into nearly every course subject. The curriculum and teaching methods could emphasize the interrelationships among all inhabitants of our global village.

Together, these practices may help children reach beyond their biological boundaries and develop a cognitive schema of relatedness to all humanity that appears to be increasingly necessary in the 21 st Century. 


\section{References}

Barnett, M. A., Howard, J. A., King, L. M., \& Dino, G. A. (1980). Antecedents of empathy: Retrospective accounts of early socialization. Personality and Social Psychology Bulletin, 6, 361-365.

Barnett, M. A., Howard, J. A., Melton, E. M., \& Dino, G. A. (1983). Effect of inducing sadness about self or other on helping behavior in high-and lowempathic children. Child Development, 53, 920-923.

Batson, C. D. (1991). The altruism question: Toward a social-psychological answer. Hillsdale, NJ: Erlbaum.

Batson, C. D., Batson, J. G., Griffitt, C. A., Barrientos, S., Brandt, J. R., Sprengelmeyer, P., \& Bayly, M. J. (1989). Negative-state relief and the empathy-altruism hypothesis. Journal of Personality and Social Psychology, 56, 922-933.

Batson, C. D., Batson, J. G., Slingsby, J. K., Harrell, K. L., Peekna, H. M., \& Todd, R. M. (1991). Empathic joy and the empathy-altruism hypothesis. Journal of Personality and Social Psychology, 61, 413-426.

Batson, C. D., Dyck, J. L., Brandt, J. R., Batson, J. G., Powell, A. L., McMaster, M. R., \& Griffitt, C. (1988). Five studies testing two new egotistic alternatives to the empathy-altruism hypothesis. Journal of Personality and Social Psychology, 55, 52-77.

Batson, C. D., O'Quin, K., Fulz, J., Vanderplas, M., \& Isen, A. M. (1983). Influence of self-reported distress and empathy on egoistic versus altruistic motivation to help. Journal of Personality and Social Psychology, 45, 706718.

Baumrind, D. (1967). Childcare practices anteceding three patterns of preschool behavior. Genetic Psychology Monographs, 75, 43-88.

Baumrind, D. (1971). Current patterns of parental authority. Developmental Psychology Monographs, 4, 1-103.

Baumrind, D. (1973). The development of instrumental competence through socialization. In A. D. Pick (Ed.). Minnesota symposium on child psychology, Vol.7. Minneapolis, MN: University of Minnesota Press.

Baumrind, D. (1978). Parental discipline patterns and social competence in children. Youth and Society, $\underline{9}, 239-276$.

Baumrind, D. (1989). Rearing competent children. In W. Damon (Ed.), Child Development Today and Tomorrow. San Francisco: Jossey-Bass.

Baumrind, D. (1991a). Parenting style and adolescent development. In R. M. Lerner, A. C. Petersen, \& J. Brooks-Gunn (Eds.), The Encyclopedia of Adolescence, Vol. 2 (pp. 746-758). New York: Garland. 
Baumrind, D. (1991b). Effective parenting during the early adolescent transition. In P. A. Cowan \& M. Heatherington (Eds.), Family Transitions. Advances in Family Research (pp. 111-163). Hillsdale, NJ: Earlbaum.

Baumrind, D., \& Black, A. E. (1967). Socialization practices associated with dimensions of competence in preschool boys and girls. Child Development, 38, 291-328.

Blasi, A. (1980). Bridging moral cognition and moral action: A critical review of the literature. Psychological Bulletin, 88, 1-45.

Borgida, E., Conner, C., \& Manteufel, L. (1992). Understanding living kidney donation: A behavioral decision-making perspective. In S. Spacapan \& S. Oskamp (Eds.), Helping and being helped: Naturalistic studies (pp. 183-211). Newbury Park, CA: Sage Publications.

Boss, J. A. (1991). Volunteer community service work and its effect on the moral development of ethics students. Unpublished master's thesis, University of Rhode Island.

Burstein, E., Crandall, C., \& Kitayama, S. (1994). Some neo-Darwinian decision rules for altruism: Weighting cues for inclusive fitness as a function of the biological importance of the decision. Journal of Personality and Social Psychology, 67, 773-789.

Burton, R. V. (1963). Generality of honesty reconsidered. Psychological Review, 70, 481-499.

Carlo, G., Eisenberg, N., Troyer, D., Switzer, G., \& Speer, A. L. (1991). The altruistic personality: In what contexts is it apparant? Journal of Personality and Social Psychology, 61, 450-458.

Chapman, M., Zahn-Waxler, C., Cooperman, G., \& lannotti, R. (1987). Empathy and responsibility in the motivation of children's helping. Developmental Psychology, 23, 140-145.

Clary, E. G., \& Miller, J. (1986). Socialization and situational influences on sustained altruism. Child Development, 57, 1358-1369.

Clary, E. G., \& Snyder, M. (1991). A functional analysis of altruism and prosocial behavior: The case of volunteerism. In M. S. Clark (Ed.), Review of personality and social psychology, Vol. 12: Prosocial behavior (pp. 119 148). Newbury Park: SAGE Publications.

Colby, A., \& Damon, W. (1992). Some do care: Contemporary lives of moral commitment. New York: The Free Press.

Coles, R. (1986). The moral life of children. Boston: Houghton Mifflin.

Damon, W. (1988). The moral child. New York: Free Press.

Darley, J. M., \& Batson, C. D. (1973). "From Jerusalem to Jericho": A study of situational and dispositional variables in helping behavior. Journal of Personality and Social Psychology, 27, 100-108. 
Davis, M. H. (1983). Measuring individual differences in empathy: Evidence for a multidimensional approach. Journal of Personality and Social Psychology, 44, 113-126.

Dodge, K. A. (1985). A social information processing model of social competence in children. In M. Perlmutter (Ed.), Cognitive perspectives on children's social and behavioral development: Minnesota Symposium on Child Psychology, Vol. 18. Hillsdale, NJ: Erlbaum.

Dyck, J. L., Batson, C. D., Oden, A., \& Weeks, J. L. (1989, April). Another look at the altruism in the altruistic personality: Hers and his. Paper presented at the meeting of the Midwestern Sociological Association, St. Louis, MO.

Eisenberg, N. (1988). The development of prosocial and aggressive behavior. In M. H. Bornstein \& M. E. Lamb (Eds.), Developmental psychology: An advanced textbook, 2nd edition (pp. 461-495). Hillsdale, New Jersey: Erlbaum.

Eisenberg, N., Fabes, R. A., Miller, P. A., Fultz, J., Shell, R., Mathy, R. M., \& Reno, R. R. (1989). Relation of sympathy and personal distress to prosocial behavior: A multimethod study. Journal of Personality and Social Psychology, 57, 55-66.

Eisenberg, N., Miller, P. A., Schaller, M., Fabes, R. A., Fultz, J., Shell, R., \& Shea, C. L. (1989). The role of sympathy and altruistic personality traits in helping: A reexamination. Journal of Personality, $\underline{57}, 41-67$.

Eisenberg, N. \& Mussen, P. H. (1989). The roots of prosocial behavior in children. NY: Cambridge University Press.

Epstein, S. (1979). The stability of behavior: I. On predicting most of the people much of the time. Journal of Personality and Social Psychology, 37, 10971126.

Epstein, S. (1980). The stability of behavior: II. Implications for psychological research. American Psychologist, 35, 790-806.

Epstein, S., \& Meier (1989). Constructive thinking: A broad coping variable with specific components. Journal of Personality and Social Psychology, $\underline{57}, 332$ 350.

Feshbach, N. D. (1979). Empathy training: A field study in affective education. In Feshbach, S. \& Fraczek, A. (Eds.), Aggression and behavior chance: Biological and social processes (pp. 234-249). NY: Praeger.

Feshbach, N. D., \& Feshbach, S. (1982). Empathy training and the regulation of aggression: Potentialities and limitations. Academic Psychological Bulletin, $\underline{4}, 399-413$.

Feshbach, N. D., \& Feshbach, S. (1983). Learning to care: Classroom activities for social and affective development. Glenview, IL: Scott, Foresman. 
Ford, M. R., \& Lowery, C. R. (1986). Gender differences in moral reasoning: A comparison of the use of justice and care orientations. Journal of Personality and Social Psychology, 50, 777-783.

Freedman, M. (1994). The kindness of stranders: Adult mentors, urban youth, and the new volunteerism. San Francisco: Josey-Bass.

Fritzsche, B. A., \& Penner, L. A. (1992, August). Individual differences in decisions to offer help: "Capturing" helpers' policies. Paper presented at the 100 th annual meeting of the American Psychological Association, Washington, D.C.

Frodi, A. M., \& Lamb, M. D. (1980). Child abuser's responses to infant smiles and cries. Child Development, $51,238-241$.

Gilligan, C. (1982). In a different voice: Psychological theory and women's development. Cambridge, MA: Harvard University Press.

Green, L. (1991). Validity studies on the family functioning scale: Family of origin version. Doctoral dissertation, University of Rhode Island.

Gresham, F. M. (1990). Best practices in social skills training. In A. Thomas \& J. Grimes (Eds.), Best practices in school psychology-ll (pp. 695-709).

Washington, D.C.: National Association of School Psychologists.

Gresham, F. M., \& Elliott, S. N. (1989). Social skills assessment technology for LD students. Learning Disability Quarterly, 12, 141-152.

Grusec, J. E. (1991). Socializing concern for others in the home. Developmental Psychology, 27, 338-342.

Grusec, J. E., Kuczynski, L., Rushton, J. P., \& Simutis, Z. M. (1978). Modeling, direct instruction, and attributions: Effects on altruism. Developmental Psychology, 14, 51-57.

Hart, D. \& Fegley, S. (in press-1993?). Altruism and caring in adolescence: Relations to moral judgment and self-understanding.

Hartshorne, H., \& May, M. A. (1928). Studies in the nature of character. Vol. I: Studies in deceit. New York: Macmillan.

Hartshorne, H., May, M. A., \& Maller, J. B. (1929). Studies in the nature of character. Vol. II: Studies in service and self-control. New York: Macmillan.

Hartshorne, H., May, M. A., \& Shuttleworth, F. K. (1930). Studies in the nature of character. Vol. III: Studies in the organization of character. New York: Macmillan.

Hoffman, M.L. (1979). Development of moral thought, feeling, and behavior. American Psychologist, 34, 958-966.

Hoffman, M. (1981). The development of empathy. In J. P. Rushton \& R. M. Sorrentino (Eds.), Altruism and helping behavior (pp. 44-61). Hillsdale, NJ: Erlbaum. 
Hoffman, M. (1988). Moral development. In M. H. Bornstein and M. E. Lamb, (Eds.), Developmental psychology: An advanced textbook (2nd ed., pp. 497548). Hillsdale, NJ: Erlbaum.

Hoffman, M. (1989). Empathy and prosocial activism. In N. Eisenberg, J. Reykowski, \& E. Staub (Eds.), Social and moral values: Individual and societal perspectives, (pp. 65-85). Hillsdale, NJ: Erlbaum.

Katz, L., \& Epstein, S. (1991). Constructive thinking and coping with laboratoryinduced stress. Journal of Personality and Social Psychology, 61, 789-800.

Keppel, G. (1991). Design and analysis: A researcher's handbook. NJ: Prentice Hall.

Koestner, R., Franz, C., Weinberger, J. (1990). The family origins of empathic concern: A 26-year longitudinal study. Journal of Personality and Social Psychology, 58, 709-717.

Kohlberg, L. \& Ryncarz, R. A. (1990). Beyond justice reasoning: Moral development and consideration of a seventh stage. In C. N. Alexander \& E. J. Langer (Eds.), Higher stages of human development: Perspectives on adult growth (pp.191-207). New York: Oxford University Press.

Krebs, D., and Miller, D. (1985). Altruism and aggression. In E. Aronson (Ed.), Handbook of social psychology, Vol. Il (3rd ed., pp. 1-72). New York: Random House.

Latane, B., \& Darley, J. M. (1968). Group inhibition of bystander intervention in emergencies. Journal of Personality and Social Psychology, 10, 215-221.

Midlarsky, E. (1984). Competence and helping: Notes toward a model. In E. Staub, D. Bar-Tal, J. Karylowski, and J. Reykowski (Eds.), The development and maintenance of prosocial behavior: International Perspectives ( $p$. 291308). New York: Plenum Press.

Midlarsky, E., \& Hannah, M.E. (1985). Competence, reticence, and helping by children and adolescents. Developmental Psychology, 21, 534-541.

Miller, P. A., \& Eisenberg, N. (1988). The relation of empathy to aggressive and externalizing/anti-social behavior. Psychological Bulletin, 103, 324-344.

Monroe, K. R. (1994). A fat lady in a corset: Altruism and social theory. American Journal of Political Science, 38, 861 - 893.

Monroe, K. R. (1991). John Donne's people: Explaining differences between rational actors and altruists through cognitive frameworks. Journal of Politics, $\underline{53}, 394-433$.

Monroe, K. R., \& Epperson, C. (1994). "But what else could I do?": Choice, identity and a cognitive-perceptual theory of ethical political behaviour. Political Psychology, 15, $210-226$.

Norusis, M.J., (1990). SPSS/PC+ Advanced Statistics 4.0 for the IBM PC/XTIAT and PS/2. Chicago, IL, SPSS Inc. 
Oliner, S. P., \& Oliner, P. M. (1988). The altruistic personality: Rescuers of Jews in Nazi Europe. NY: Free Press.

Penner, L.A., February, 1993. Personal communication to "People Interested in Prosocial Personality Measure". University of South Florida, Tampa, FL.

Penner, L. A., \& Fritzsche, B. A. (1992). Affective and cognitive correlates of individual differences in altruistic tendencies. Paper presented at the Fifth International Nagshead Conference on Personality and Social Behavior, Boca Raton, Florida.

Peterson, L. (1983). Influence of age, task competence, and responsibility focus on children's altruism. Developmental Psychology, 19, 141-148.

Piaget, J. (1965). The moral judgment of the child (translated by Marjorie Gabain). New York: The Free Press.

Piliavin, J. A., \& Charng, H. W. (1990). Altruism: A review of recent theory and research. Annual Review of Sociology, 16, 27-65.

Piliavin, J. A. \& Libby D. (1985/86). Personal norms, perceived social norms, and blood donation. Humboldt Journal of Social Relations, 13, 159-194.

Radke-Yarrow, M., \& Zahn-Waxler, C. (1984). Roots, motives, and patterns in children's prosocial behavior. In E. Staub, D. Bar-Tal, J. Karylowski, and J. Reykowski (Eds.), The development and maintenance of prosocial behavior: International Perspectives (pp. 81-100). New York: Plenum Press.

Rosenhan, D. L. (1970). The natural socialization of altruistic autonomy. In J. Macaulay \& L. Berkowitz (Eds.), Altruism and helping behavior. New York: Academic Press.

Rosenhan, D. L. (1972). Learning theory and prosocial behavior. Journal of Social Issues, 28 , 151-164.

Rushton, J. P. (1975). Generosity in children: Immediate and long term effects of modeling, preaching, and moral judgment. Journal of Personality and Social Psychology, 31, 459-466

Rushton, J. P. (1976). Socialization and the altruistic behavior of children. Psychological Bulletin, 83, 898-913.

Rushton, J. P. (1984). The altruistic personality: Evidence from laboratory, naturalistic, and self-report perspectives. In E. Staub, D. Bar-Tal, J. Karylowski, and J. Reykowski (Eds.), The development and maintenance of prosocial behavior: International Perspectives (pp. 271-290). New York: Plenum Press.

Rushton, J. P., Chrisjohn, R. D., \& Fekken, G. C. (1981). The altruistic personality and the Self-Report Altruism Scale. Personality and Individual Differences, 2, 293-302. 
Rushton, J. P., \& Littlefield, C. (1979). The effects of age, amount of modeling, and a success experience on seven- to eleven-year-old children's generosity. Journal of Moral Education, 9 , 55-56.

Schwartz, S. H. (1967). Moral orientations and interpersonal conduct in moral encounters. Doctoral Dissertation, University of Michigan, Ann Arbor.

Schwartz, S. H. (1968). Words, deeds, and the perception of consequences and responsibility in action situations. Journal of Personality and Social Psychology, 10, 232-242.

Schwartz, S. H., \& Howard, J., (1984). Internalized values as motivators of altruism. In E. Staub, D. Bar-Tal, J. Karylowski, and J. Reykowski (Eds.), The development and maintenance of prosocial behavior: International Perspectives (pp. 229-255). New York: Plenum Press.

Snyder, M. \& Omoto, A. M. (1992). Who helps and why? The psychology of AIDS volunteerism. In S. Spacapan \& S. Oskamp (Eds.), Helping and being helped: Naturalistic studies (pp. 213-239). Newbury Park, CA: Sage Publications.

Steinberg, L., Lamborn, S. D., Dornbusch, S. M., \& Darling, N. (1992). Impact of parenting practices on adolescent achievement: Authoritative parenting, school involvement, and encouragement to succeed. Child Development, $\underline{63}$, 1266-1281.

Steinberg, L., Mounts, N., Lamborn, S., \& Dornbusch, S. M. (1991).

Authoritative parenting and adolescent adjustment across various ecological niches. Journal of Research on Adolescence, 1, 19-36.

Stiff, J. B., Dillard, J. P., Somera, L., Kim, H., \& Sleight, C. (1988). Empathy, communication, and prosocial behavior. Communication Monographs, $\underline{55}$, 198-213.

Tabachnick, B.G. \& Fidell, L.S. (1989). Using Multivariate Statistics, Second Edition. New York, Harper \& Row.

Werner, E. E., \& Smith, R. S. (1992). Overcoming the odds: High risk children from birth to adulthood. Ithica, NY: Cornell University Press.

Wilson, E. O. (1975). Sociobiology: The new synthesis. Cambridge, MA: Belknap Press.

Zahn-Waxler, C., \& Radke-Yarrow, M. (1982). The development of altruism: Alternative research strategies. In N. Eisenberg (Ed.), The development of prosocial behavior (pp. 109-137). San Diego, CA: Academic Press.

Zahn-Waxler, C., Radke-Yarrow, M., \& King, R. A. (1979). Childrearing and children's prosocial intentions toward victims of distress. Child Development, 50, 319-330.

Zahn-Waxler, C., Radke-Yarrow, M., Wagner, E., \& Chapman, M. (1992). Development of concern for others. Developmental Psychology, 28, 126-136. 


\title{
APPENDIX A \\ Informed Consent Statement for School and Home Experiences Survey
}

\author{
The University of Rhode Island \\ Department of Psychology \\ Chafee Hall \\ Kingston, RI 02881
}

\section{Purpose of this project}

I understand that the purpose of this project is to gather information about various aspects of students' school and home experiences, including family background, personal attitudes, educational and leisure activities, emotions, and preferences. I understand that my participation is voluntary, and that I should feel free to ask questions of the instructor or supervisor that distributed this questionnaire.

\section{What my participation involves}

I understand that I am being asked to complete and return by mail the enclosed questionnaire that contains questions about the areas mentioned above. I understand that I should complete the survey as fully and honestly as possible. I understand that this survey should take about 30 minutes to complete.

Although there will be no direct benefit to me for taking part in this study, the researcher may learn more about how people's feelings and experiences influence each other.

\section{Right to discontinue}

The decision whether or not to participate in this study is up to me. This survey does not involve any risk. If, however, I am uncomfortable answering the questions, 1 may discontinue filling out the survey at any time. Whether I complete or quit the survey will in no way affect my grade or performance review in the course or organization through which this survey was distributed, or my status at the University.

\section{Guarantee of confidentiality}

I understand that all information gathered in this study will be kept strictly confidential and anonymous. My name appears on this consent form and on an optional contact-page; these will be separated from the survey as soon as they are received by the researcher. A code number has been assigned to the questionnaire for record-keeping purposes only. All answers will be tabulated, analyzed, and reported anonymously.

\section{If I have any questions, complaints, or comments}

If I have any questions, complaints, or comments, I understand that I may contact Sara Little at (401) 792-2193 or Dr. Janet Kulberg at (401) 792-4228. If I am not satisfied with the way this study is performed, I may discuss my complaints with Ms. Little or Dr. Kulberg anonymously if I choose. In addition, I may contact the office of the Vice Provost for Research, 70 Lower College Road, University of Rhode Island, Kingston, Rhode Island, telephone: (401) 792-2635.

\section{Certification of participation}

I have read the Consent Form. My questions have been answered. My signature on this form means that I understand the information and I agree to participate in this study. 


\section{APPENDIX B}

\section{School and Home Experiences Survey}

I. Name of organization:

II. Please briefly describe your activities or responsibilities:

III. Average number of hours per week you spend involved with this organization:

IV. How long have you been involved with this organization?

$V$. Does your involvement with this organization give you any of the following benefits (please check all that apply): pay course credit (or extra credit, or fulfills a course requirement) fulfills a service requirement for a fraternity, sorority, university, or other group (e.g., church, scouts)

fulfills parents' or family's expectations provides relevant experience for career goals (i.e., will be directly relevant on your resume)

The following questions are open-ended in order to give you an opportunity to express your own thoughts about your involvement in this organization. Please use the back of this page if additional space is needed

VI. Please explain what initially motivated you to become involved in this organization.

VII. What currently motivates you to stay involved in this organization? 


\section{School and Home Experiences Survey}

Please circle the response that applies to your situation:

1. Age at last birthday
a. less than 18 years old
b. $18-20$ years old
c. 21-23 years old
d. 24-26 years old
e. more than 26 years old

2. Gender: a. Male b. Female

3. Academic status
a. freshman
b. sophomore
c. junior
d. senior
e. non-matriculating student

4. How many credits are you taking this semester?
a. 0-8
b. 9-11
c. $12-14$
d. 15-17
e. 18 or more

5. Approximately what percentage of your college expenses do you pay from your own earnings? (include tuition, books, fees, living expenses)
a. none
b. $25 \%$ or less
c. from $26 \%$ to $50 \%$
d. from $51 \%$ to $75 \%$
e. from $76 \%$ to $100 \%$

6. Approximately how many hours a week do you spend in paid employment during the semester (include student work-study jobs)?
a. 0-6 hours per week
b. 7-12 hours per week
c. 13-18 hours per week
d. 19-24 hours per week
e. more than 24 hours per week

7. Approximately how many hours a week do you spend on required family obligations during the semester (e.g., child care, caring for elderly or sick relatives)?
a. less than 5 hours per week
b. 5-10 hours per week
c. 11-15 hours per week
d. 16-20 hours per week
e. 20 or more hours per week

8. Your position in the family in which you grew up is:
a. only child
b. first or oldest child
c. a middle child (not youngest or oldest)
d. youngest child

9. Please list your college major (or intended major), and minor (or intended minor): major: minor: 
Below are a number of statements which may or may not describe you, your feelings, or your behavior. Please read each statement carefully and write the number which corresponds to your choice of answer on the space next to each question. There are no right or wrong responses.

\section{Use the following scale to indicate your answer:}

\begin{tabular}{|ccccc|}
\hline $\begin{array}{c}\text { Strongly } \\
\text { Agree }\end{array}$ & 2 & 3 & 4 & 5 \\
\hline
\end{tabular}

10. I wouldn't feel that I had to do my part in a group project if everyone else was lazy.

11. When a person is nasty to me, I feel very little responsibility to treat that person well.

12.If a good friend of mine wanted to injure an enemy of his or hers, it would be my duty to stop him/her.

13. I would feel less bothered about leaving litter in a dirty park than in a clean one.

14. No matter what a person has done to us, there is no excuse for taking advantage of that person.

15. You can't blame basically good people who are forced by their environment to be inconsiderate of others.

16. No matter how much a person is provoked, they are always responsible for whatever they do.

17. Being upset or preoccupied does not excuse a person for doing anything she or he would ordinarily avoid.

18. As long as a businessperson doesn't break laws, he or she should feel free to do business as they see fit.

19. Occasionally in life a person finds themselves in a situation in which they have absolutely no control over what they do to others.

20. I would feel obligated to do a favor for a person who needed it. even though they had shown no gratitude for past favors.

21. With the pressure for grades and the widespread cheating in school nowadays, the individual who cheats occasionally is not really as much at fault. 


\begin{tabular}{|ccccc|}
\hline $\begin{array}{c}1 \\
\text { Strongly } \\
\text { Agree }\end{array}$ & Agree & Uncertain & $\begin{array}{c}4 \\
\text { Disagree }\end{array}$ & $\begin{array}{c}5 \\
\text { Strongly } \\
\text { Disagree }\end{array}$ \\
\hline
\end{tabular}

22. It doesn't make much sense to be very concerned about how we act when we are sick and feeling miserable.

23. If I broke a machine through mishandling, I would feel less guilty if it was already damaged before I used it.

24. When you have a job to do, it is impossible to look out for everybody's best interest.

25. I often have tender, concerned feelings for people less fortunate than me.

26. I sometimes find it difficult to see things from the "other person's" point of view.

27. Sometimes I don't feel very sorry for other people when they are having problems.

28. In emergency situations, I feel apprehensive and ill-at-ease.

29. I try to look at everybody's side of a disagreement before I make a decision.

30. When I see someone being taken advantage of, I feel kind of protective towards them.

31. I sometimes try to understand my friends better by imagining how things look from their perspective.

32. Other people's misfortunes do not usually disturb me a great deal.

33. If I'm sure I'm right about something, I don't waste much time listening to other people's arguments.

34. Being in a tense emotional situation scares me.

35. When I see someone being treated unfairly, I sometimes don't feel very much pity for them.

36. I am usually pretty effective in dealing with emergencies.

37. I am often quite touched by things that I see happen. 


\begin{tabular}{|ccccc|}
\hline $\begin{array}{c}1 \\
\begin{array}{c}\text { Strongly } \\
\text { Agree }\end{array}\end{array}$ & Agree & Uncertain & Disagree & $\begin{array}{c}\text { Strongly } \\
\text { Disagree }\end{array}$ \\
\hline
\end{tabular}

38. I believe that there are two sides to every question and try to look at them both.

39. I would describe myself as a pretty soft-hearted person.

40. I tend to lose control during emergencies.

41. When I'm upset at someone, I usually try to "put myself in their shoes" for a while.

42. When I see someone who badly needs help in an emergency, I go to pieces.

43. Before criticizing somebody, I try to imagine how / would feel if I were in their place. 
Below are a set a statements which may or may not describe how you make decisions when you have to choose between two courses of action or alternatives when there is no clear right way or wrong way to act. Some examples of such situations are: being asked to lend something to a close friend who often forgets to return things; deciding whether you should keep something you have won for yourself or share it with a friend; and choosing between studying for an important exam and visiting a sick relative. Read each statement and write the number that corresponds to your choice of answer on the space next to the statement.

Use the following scale to indicate your answer:

\begin{tabular}{|ccccc|}
\hline $\begin{array}{c}1 \\
\text { Strongly } \\
\text { Agree }\end{array}$ & 2 & 3 & 4 & 5 \\
\hline
\end{tabular}

44. My decisions are usually based on my concern for other people.

45. My decisions are usually based on what is the most fair and just way to act.

46. I choose alternatives that are intended to meet everybody's needs.

47. I choose a course of action that maximizes the help other people receive.

48. I choose a course of action that considers the rights of all people involved.

49. My decisions are usually based on concern for the welfare of others.

50. My decisions are usually based on my personal principles about what is fair and unfair.

51. I choose alternatives that minimize the negative consequences to other people. 
Please answer the next set of questions about the parents (or guardians) you lived with during your last two years of high school. If you spent time in more than one home, answer the questions about the parents (or guardians) who had the most say over your daily life. Read each item carefully. Then write the number that shows how much you agree with each statement:
1 -if You AGREE STRONGLY with the item
2 -if You AGREE SOMEWHAT with the item
3 -if You DISAGREE SOMEWHAT with the item
4 -if You DISAGREE STRONGLY with the item

52. I could count on my parents to help me out, if I had some kind of problem.

53. My parents said that you shouldn't argue with adults.

54. My parents kept pushing me to do my best in whatever I did.

55. My parents said that you should give in on arguments rather than make people angry.

56. My parents kept pushing me to think independently.

57. When I got a poor grade in school, my parents made my life miserable.

58. My parents helped me with my school work if there was something I didn't understand.

59. My parents told me that their ideas were correct and that I should not question them.

60. When my parents wanted me to do something, they explained why.

61. Whenever I argued with my parents, they said things like, "You'll know better when you grow up."

62. When I got a poor grade in school, my parents encouraged me to try harder.

63. My parents let me make my own plans for things I wanted to do.

64. My parents knew who my friends were.

65. My parents acted cold and unfriendly if I did something they didn't like.

66. My parents spent time just talking with me.

67. When I got a poor grade in school, my parents made me feel guilty.

68. My family did fun things together.

69. My parents wouldn't let me do things with them when I did something they didn't like. 
For each question, please check the answer that describes your situation during your last two years of high school.

70. In a typical week, what was the latest you could stay out on SCHOOL NIGHTS (Monday - Thursday)?

$$
\begin{gathered}
\text { I was not allowed out } \\
\text { Before } 8: 00 \\
8: 00 \text { to } 8: 59 \\
9: 00 \text { to } 9: 59 \\
\text { 10:00 to } 10: 59 \\
\text { 11:00 or later } \\
\text { As late as I wanted }
\end{gathered}
$$

71. In a typical week, what was the latest you could stay out on FRIDAY or SATURDAY NIGHT?

$$
\begin{gathered}
\text { I was not allowed out } \\
\text { Before } 8: 00 \\
8: 00 \text { to } 8: 59 \\
9: 00 \text { to } 9: 59 \\
\text { 10:00 to } 10: 59 \\
\text { 11:00 or later } \\
\text { As late as I wanted }
\end{gathered}
$$

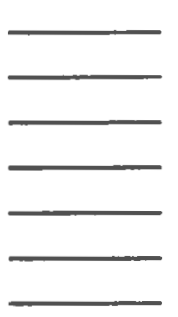

How much did your parents TRY to know...

$$
\text { Didn't try Tried a little } \begin{gathered}
\text { Tried a } \\
\text { lot }
\end{gathered}
$$

72. Where you went at night?

73. What you did with your free time?

74. Where you were most afternoons after school?

How much did your parents REALLY know...

$$
\text { Didn't know Knew a little } \begin{gathered}
\text { Knew a } \\
\text { lot }
\end{gathered}
$$

75. Where you went at night?

76. What you did with your free time?

77. Where you were most afternoons after school? 
Dse the scale below to rate the following statements about feelings, beliefs, and behaviors. score "1" if the statement is definitely false, "2" if it is mostly false, "4" if it is mostly true, and "5" if it is definitely true. Use " 3 " only if you cannot decide if the item is mainly true or false.

\begin{tabular}{|c|c|c|c|c|}
\hline 1 & 2 & 3 & 4 & 5 \\
\hline \multicolumn{5}{|c|}{ Undecided or } \\
\hline Definitely & Mostly & Equally & Mostly & Definitely \\
\hline False & False & $\begin{array}{c}\text { False and } \\
\text { True }\end{array}$ & True & True \\
\hline
\end{tabular}

78. When I have a lot of work to do by a deadline, I waste a lot of time worrying about it instead of just doing it.

79. I tend to classify people as either for me or against me.

80. When doing unpleasant chores, I make the best of it by thinking pleasant or interesting thoughts.

81. I don't let little things bother me.

82. I look at challenges not as something to fear, but as an opportunity to test myself and leam.

83. I take failure very hard.

84. I spend much more time mentally rehearsing my failures than remembering my successes.

85. I've leamed not to hope too hard, because what I hope for usually doesn't happen.

86. If I said something foolish when I spoke up in a group, I would chalk it up to experience and not worry about it.

87. When faced with a large amount of work to complete, I tell myseif I can never get it done, and feel like giving up.

88. The slightest indication of disapproval gets me upset.

89. I worry a great deal about what other people think of me.

90. When I am faced with a difficult task, I think encouraging thoughts that help me do my best.

91. I am the kind of person who takes action rather than just thinks or complains about a situation. 


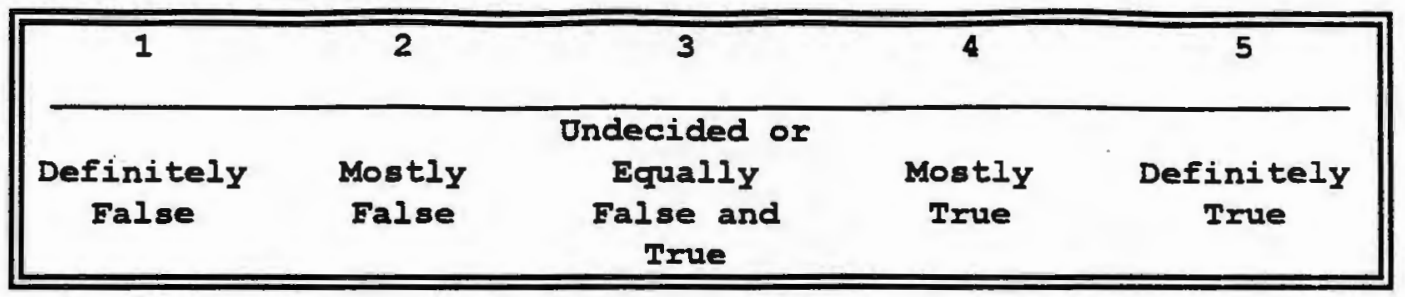

92. I believe it is best, in most situations, to emphasize the positive side of things.

93. If I have something unpleasant to do, I try to make the best of it by thinking in positive terms.

94. I feel like a total failure if I don't achieve the goals I set for myself.

95. I am tolerant of my mistakes as I feel they are a necessary part of learning.

96. I avoid challenges because it hurts too much when I fail.

97. I spend a lot of time thinking about my mistakes even if there is nothing I can do about them.

98. I like to succeed, but I don't take failure as a tragedy.

99. It is foolish to trust anyone completely, as if you do, you are bound to get hurt.

100. I tend to dwell more on pleasant than unpleasant incidents from the past.

101. I get so distressed when I notice that I am doing poorly in something that it makes me do worse.

102. When unpleasant things happen to me, I don't let them prey on my mind.

103. If I do very poorly on a test, I realize it is only a single test, and it doesn't make me feel generally incompetent.

104. I don't get very distressed over the mistakes of others, but try to deal with them in a constructive way.

105. I have learned from bitter experience that most people are not trustworthy.

106. When I am faced with a new situation, I tend to think the worst possible outcome will happen. 
For the following questions, please indicate about how much time you spend this semester in each of the activities that is listed. Please do not count the same hours twice.

For questions that ask about volunteer activities, please count only hours for which you did not receive pay, credit, or other kinds of remuneration.

107. About how many hours per week do you spend participating in professional organizations, honors clubs, or business or political organizations (e.g., Psi-chi, Business and Professional Women's Association, Young Democrats, etc.), or doing unpaid work that would advance your career?
a. none
b. an average of about 1 - 2 hours a week
c. an average of about 3 - 4 hours a week
d. an average of about 5 - 6 hours a week
e. an average of about 7 or more hours a week

Name, or type, of organization(s):

108. About how many hours per week do you spend in organized and/or informal group sports (e.g., membership on a sports team, informal sports with friends)?
a. none
b. an average of about 1 - 2 hours a week
c. an average of about 3 - 4 hours a week
d. an average of about $5-6$ hours a week
e. an average of about 7 or more hours a week

109. About how many hours per week do you spend in unpaid volunteer work that benefits people in need, or the environment (e.g., Big Brother/Big Sister, Habitat for Humanity, legal or social activism, soup kitchen, homeless shelter, prison, hospital, hospice, nursing home, crisis center, suicide hotline, informal self-help group, recycling center, rescue squad, fire department, campus escort service, legal aid, etc.)?
a. none
b. an average of about $1-2$ hours a week
c. an average of about 3 - 4 hours a week
d. an average of about 5 - 6 hours a week
e. an average of about 7 or more hours a week

Name, or type, of organization(s) 
110. About how many hours per week do you spend in other helping activities not listed above, that do not benefit you directly (e.g., providing intensive care or running frequent errands for a sick or elderly relative or neighbor; baby-sitting for a neighbor's children for free)?
a. none
b. an average of about 1 - 2 hours a week
c. an average of about $3-4$ hours a week
d. an average of about $5-6$ hours a week
e. an average of about 7 or more hours a week

111. About how many hours per week do you spend in formal and informal social activities that were not reported in the questions above (e.g., dating; visiting, partying, or going out with friends; sorority or fraternity meetings or events; other social club memberships or activities, etc.)?
a. none
b. an average of about $1-2$ hours a week
c. an average of about $3-4$ hours a week
d. an average of about $5-6$ hours a week
e. an average of about 7 or more hours a week

112. Have you ever risked your own safety to rescue someone from a dangerous situation? (for example, from a fire, possible drowning, serious accident, robbery, rape, assault, or other violence? or donated a kidney?)
a. never
b. once
c. twice
d. three times
e. more than three times

Please answer the following question about your high-school experiences:

113. How often did you participate in unpaid community service or volunteer activities during your high school years? (For this question, please include all unpaid participation, regardless of motivation; i.e., include volunteer work or community service done for course credit, done to meet graduation, scouting, or church requirements, or done to satisfy parental or peer pressure.)

a. An average of about one hour per month or less

b. An average of about 2 to 4 hours per month

c. An average of about 5 to 7 hours per month

d. An average of about 8 to 10 hours per month

e. An average of over 10 hours per month 


\section{School and Home Experiences Survey}

\section{ADDENDUM}

If you would like to receive a brief summary of the results of this study, and/or if you are willing to be contacted for a follow-up survey in the future, please check the appropriate box and fill in your permanent address.

Yes, please send me a brief summary of the results of this study. Yes, I would consider participating in a follow-up survey in the future (at least 6 months from now).

Name:

PERMANENT Address:

Please note: This page will be separated from your questionnaire as soon as it is received in order to maintain the anonymity of the questionnaires. 


\section{APPENDIX C}

\section{NOTICES TO STUDENTS (SOLICITING PARTICIPATION)}

Dear Members,

We have been invited to participate in a study of campus organizations by a doctoral student at the University of Rhode Island. I will be distributing the questionnaires shortly. Your participation is entirely voluntary, and all responses will be confidential and anonymous. I encourage you to take the time to fill out the questionnaire, since information gained by such studies may help organizations such as ours.

In addition, for each questionnaire that is returned within 2 weeks, the researcher will donate $\$ 2.00$ to our organization. Your participation in this study can serve as a fundraiser for our group, if you specify on the questionnaire that you want the donation to go to our group.

Please return your completed, sealed questionnaire to my mailbox as soon as possible after I distribute them. I will be returning all completed questionnaires to the researcher within 2 weeks, and hope that yours is among them. 
Dear student,

Thank you for volunteering to participate in my dissertation research study. By completing this questionnaire, you are helping us learn more about what college students think and feel, and about how they choose to spend their time.

Please read and sign the enclosed Informed Consent Statement before filling out the questionnaire. Keep one copy of the consent statement for yourself, and return one copy with the questionnaire. Then, please answer the questionnaire as honestly as you can (allow about 20-30 minutes). When you are done, please seal the envelope, and return it to your program director.

Thank you again for helping with my dissertation.

Sincerely,

Sara Little

P.S. To thank your organization for assisting with the distribution of this study, I plan to donate a small $\$$ \$2.00) honorarium for each completed questionnaire that is returned within two weeks. To assure that the honorarium for your questionnaire is sent to the right organization (or to your choice of subgroup within your organization), please iist the organization or group below:

Please send the $\$ 2.00$ donation to: 
ATTENTION UNDERGRADUATES

EARN $\$ 2.00$ IN 20 MINUTES

while you

HELP A GRAD STUDENT EARN HER DEGREE

If you are an undergraduate willing to take 20 minutes to fill out a questionnaire for my dissertation research on student activities, you will earn $\$ 2.00$ and help me get closer to earning my doctorate.

(:) It's a great way to take a break from final-exam tensions!

\section{WHAT'S INVOLVED:}

1. Pick up a questionnaire from me or my assistant here in the lobby of the Student Union.

2. Fill out the questionnaire here at our table or nearby --e.g., in the cafeteria. (You can even fill it out while you eat.)

3. Return the questionnaire to me here at my table before 5PM.

4. I will give you a $\$ 2.00$ honorarium and my sincere THANKS for your help with my dissertation.

If you have any questions, please feel free to come by and ask-I'll be happy to talk with you---

Sincerely,

Sara Little 


\section{APPENDIXD}

Descriptions of the four participating universities:

University \#1: Large (approx.15,000 undergraduates), private metropolitan university with a diverse student population from 54 states and territories and 129 other countries. Fields most often chosen by graduates: business management and administrative services, social sciences, communications and journalism.

University \#2: Suburban university (approx. 3,000 undergraduates); attracts students with liberal political orientation and is known for emphasis on social action. Fields most often chosen by graduates: social sciences, ethnic studies, biological and life sciences.

University \# 3: Urban, Ivy League university (approx. 6,000 undergraduates) described as progressive, untraditional, diverse and challenging. Seeks students who are independent, self-motivated, and open-minded. Fields most often chosen by graduates: social sciences, biological and life sciences, physical sciences.

University \# 4: Public university (approx. 10,000 undergraduates) in a small town; approximately $50 \%$ of students are from that state. Students are likely to have a broader range of socio-economic backgrounds than students from the other three (private) universities. Fields most often chosen by graduates: interdisciplinary studies, health professions, business management.

Derived from Peterson's College Database, Compuserve (November, 1994) and Fischgrund, T. (Ed.), (1991). Barron's Top 50: An inside look at America's best colleges. 


\section{Appendix E}

Figure 1

Interaction of Organization Membership and University on Parental Involvement/Acceptance for Non Altruists ( $N=252)$

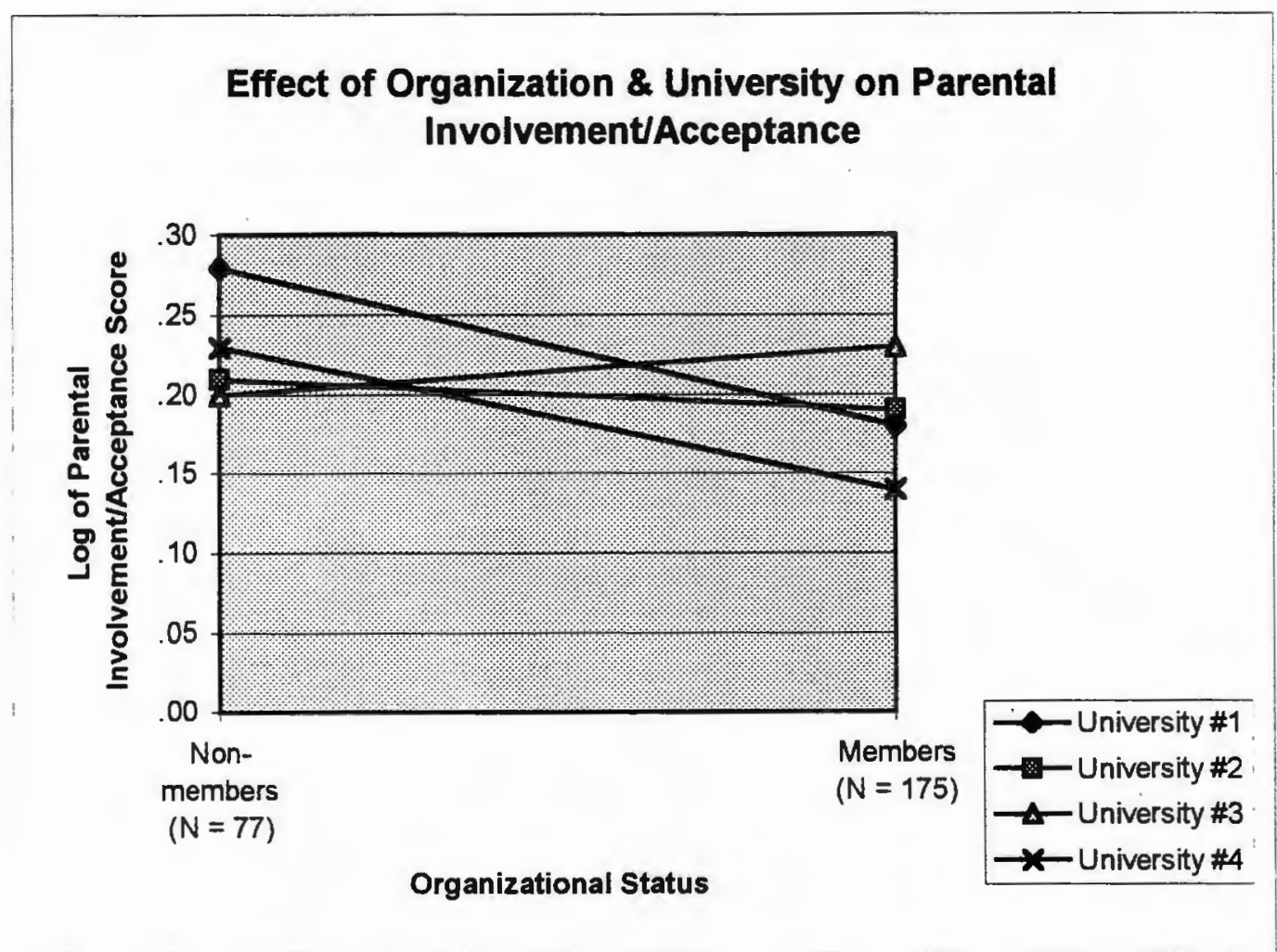

Note. Higher scores indicate lower levels of parental involvementacceptance.

Mean scores for (Log of) Parental Involvement/Acceptance for Non-Altruists $(\mathrm{N}=252)$

\begin{tabular}{cccccc}
\hline $\begin{array}{c}\text { Organizational } \\
\text { Status }\end{array}$ & $\begin{array}{c}\text { University } \\
\# 1\end{array}$ & $\begin{array}{c}\text { University } \\
\text { S2 }\end{array}$ & $\begin{array}{c}\text { University } \\
\text { S3 }\end{array}$ & $\begin{array}{c}\text { University } \\
\text { Marginal }\end{array}$ & $\begin{array}{c}\text { Mans } \\
\text { Means }\end{array}$ \\
\hline $\begin{array}{c}\text { Non-members } \\
(\mathrm{N}=77)\end{array}$ & .28 & .21 & .20 & .23 & .24 \\
$\begin{array}{c}\text { Members }(\mathrm{N}= \\
175)\end{array}$ & .18 & .19 & .23 & .14 & .20 \\
\hline $\begin{array}{c}\text { Combined } \\
\text { Means }\end{array}$ & .21 & .20 & .22 & .17 & .21 \\
\hline
\end{tabular}



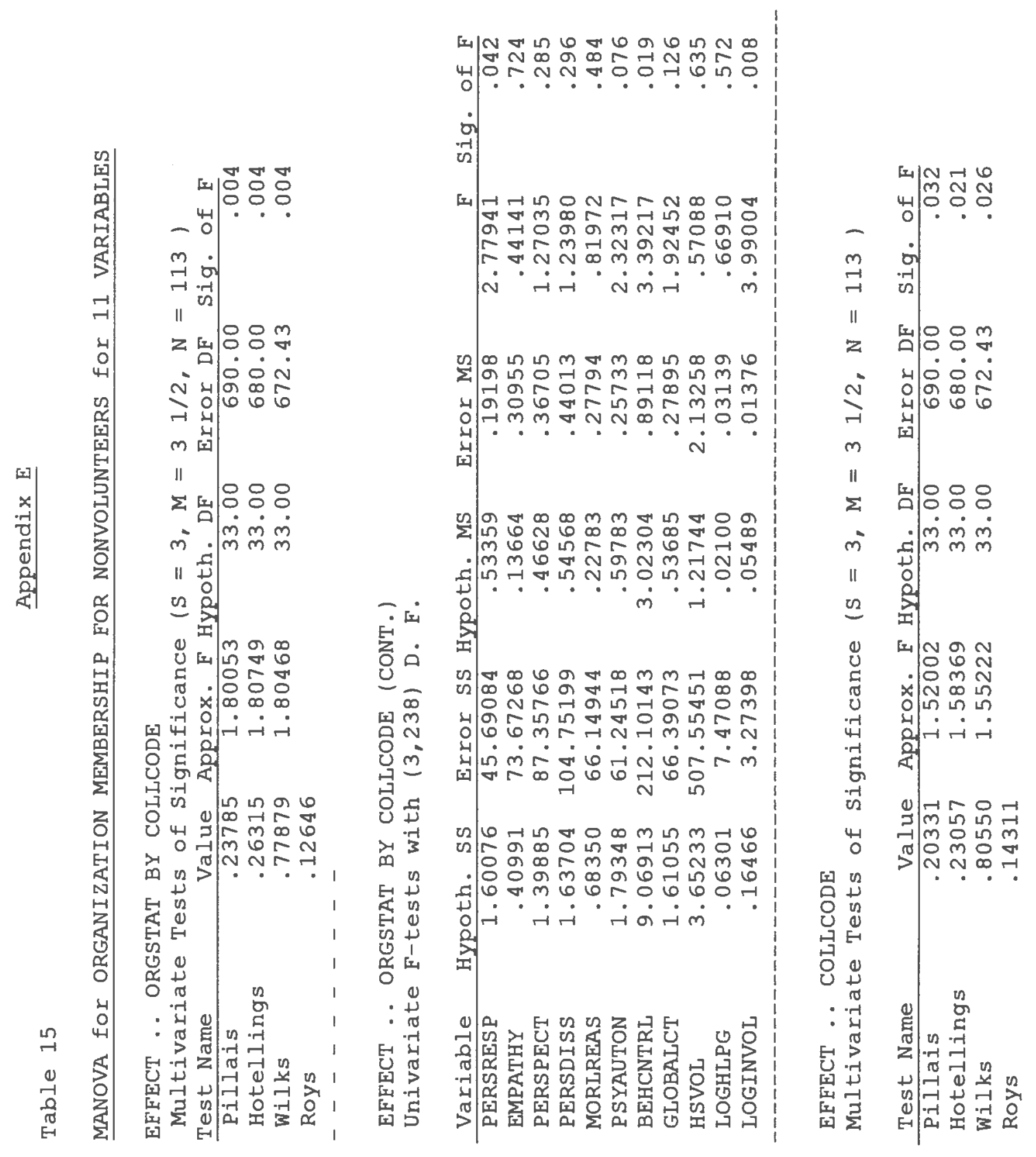

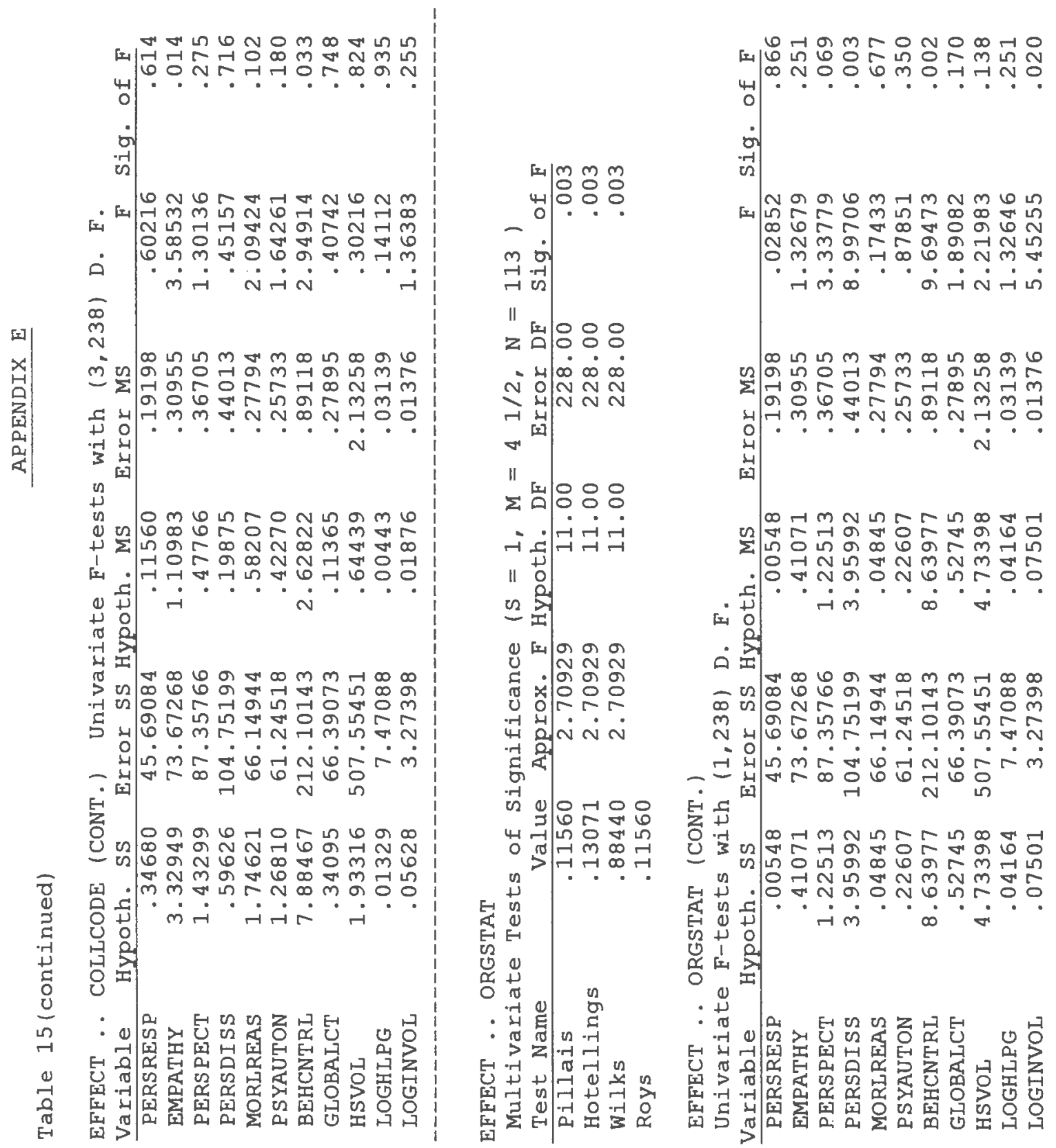

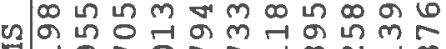

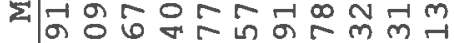

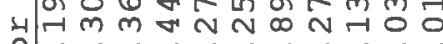
मे

되

ข $\ln _{*}^{\infty}$ $\sum$ i० 0 in $\infty$ o - 䄵.

⿷匚⿳丨コ丨

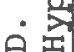

n क ⿰纟冈卩 $m$ or in in vण ${ }^{\circ}$ in N تं - ᄃ

这 $\frac{1}{1}$

员 था

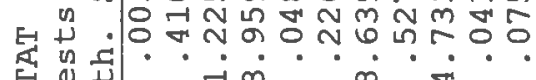

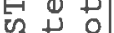

0 员 的

.

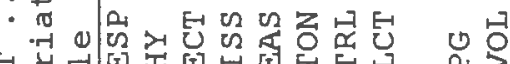

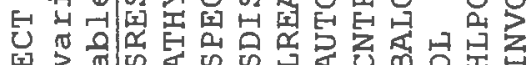

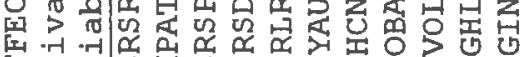

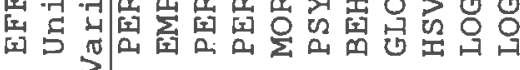




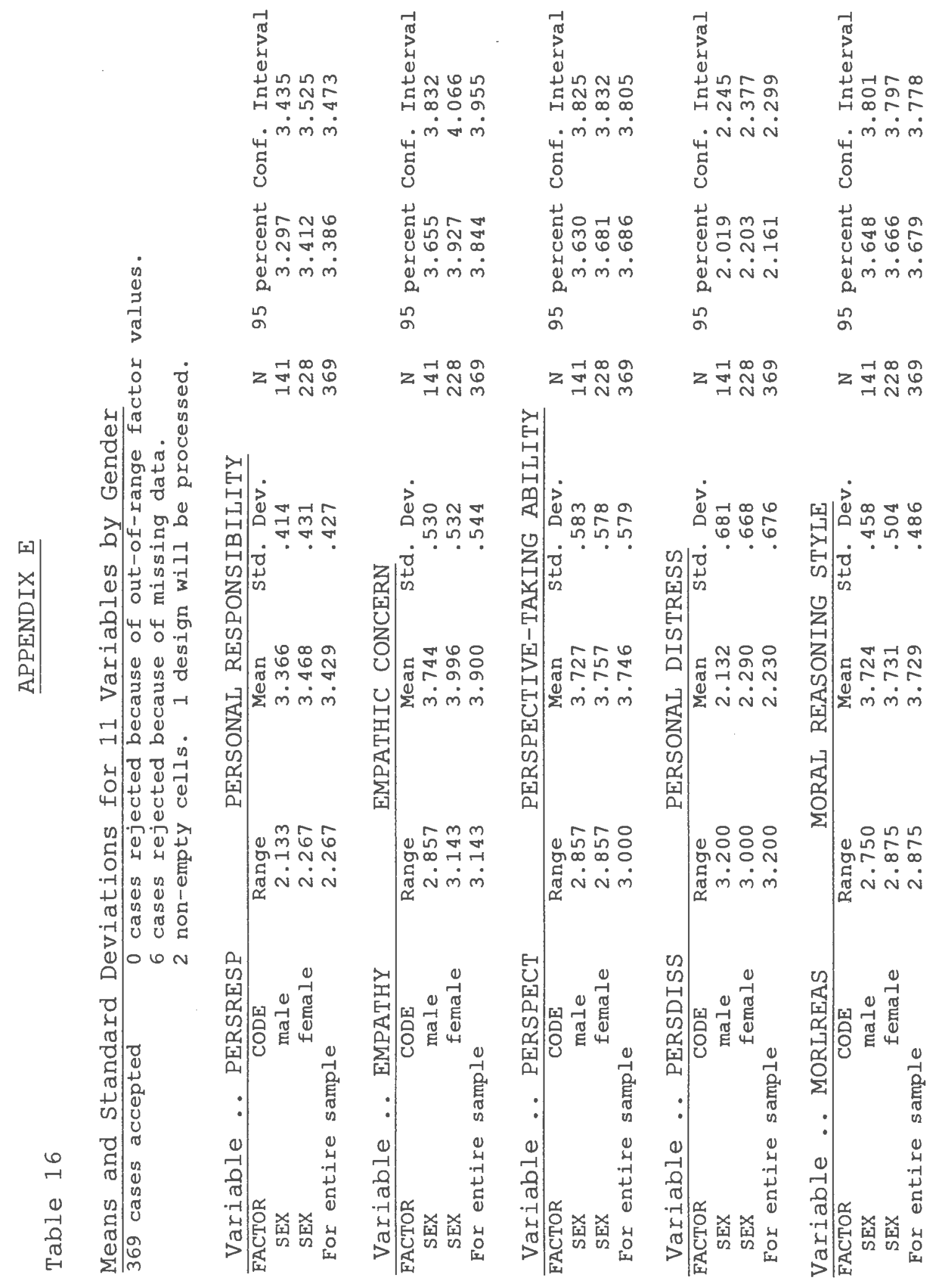


$\sum_{\substack{\pi \\ 0}}^{-1}$

胥

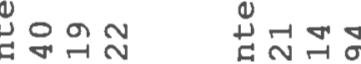

HNN

嵌

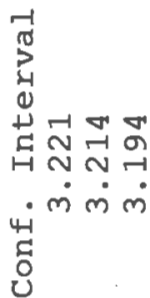

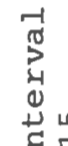

20

$\sum_{\substack{0 \\ 0}}^{\pi}$

嵌

. เ่

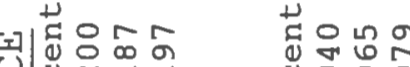

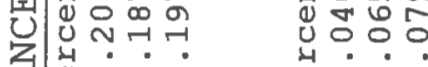

बेंm

田

2.

됭

U

ผ

䓀 $0 m$

ปัต

मे

的的

n

吉迸尔员

- $\dot{\text { mं }}$

U⿺

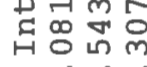

논응융

造

- $\dot{m} \dot{m} \dot{m}$

范

누요

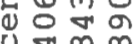

पें

a m $m$

ถั

范口下

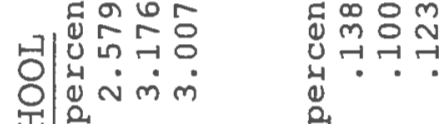

เั

咨

Uा

n

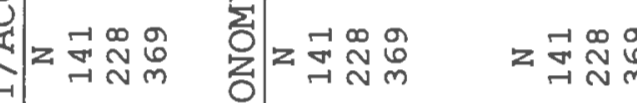

(191

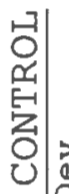

近

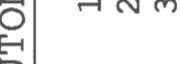

$\sin n$

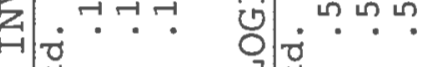

is

实就

늠

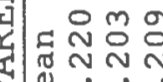

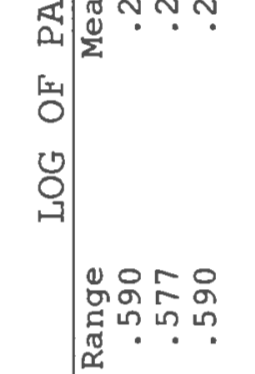

2) $\rightarrow$ a 0

מ.

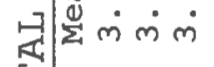

空

空

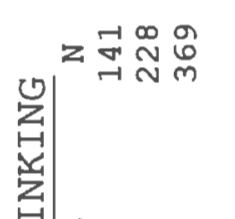

忈豆宁心

z 교요 $\stackrel{\infty}{\sim}$

而

Z

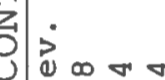

舟兵

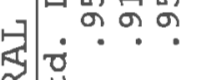

痋空

艺茫

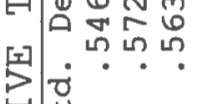

号就

空

比

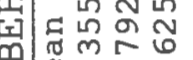

م

的

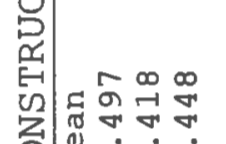

ठU

空

吕

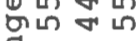

ี่ $\dot{\sim}$

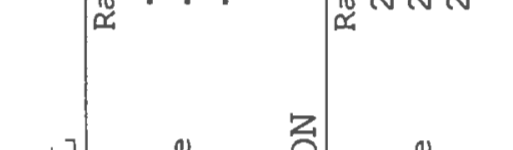

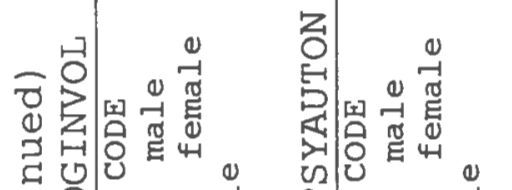

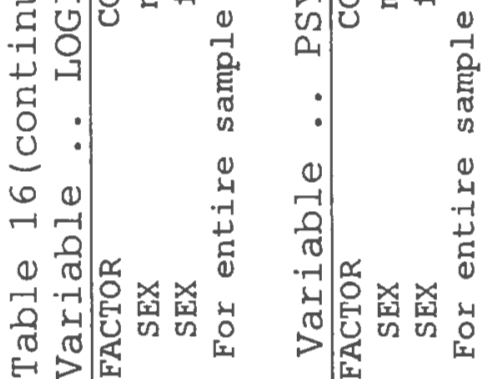

㓙

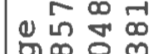

的

ตัด

ये $N m \infty$

ดㅇำ $\sigma$

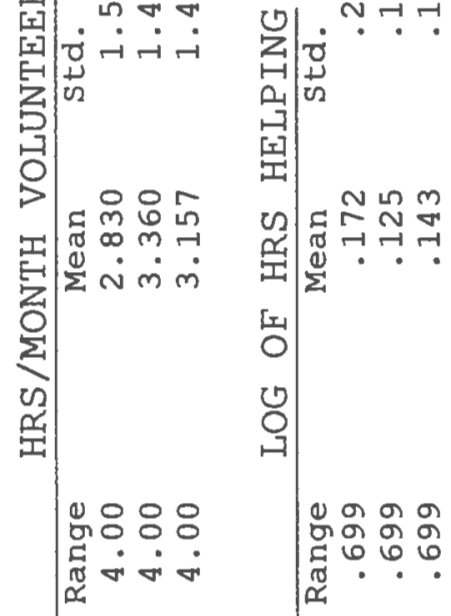

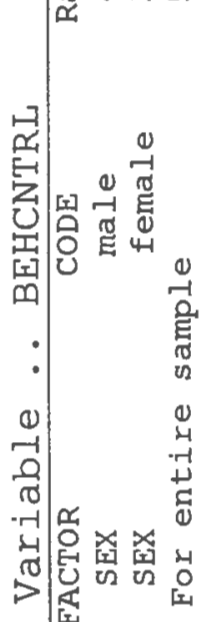

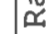

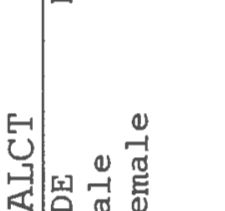

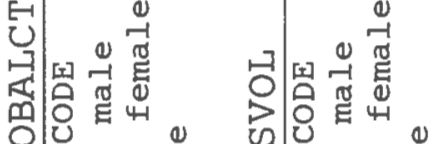

:

:|

| 


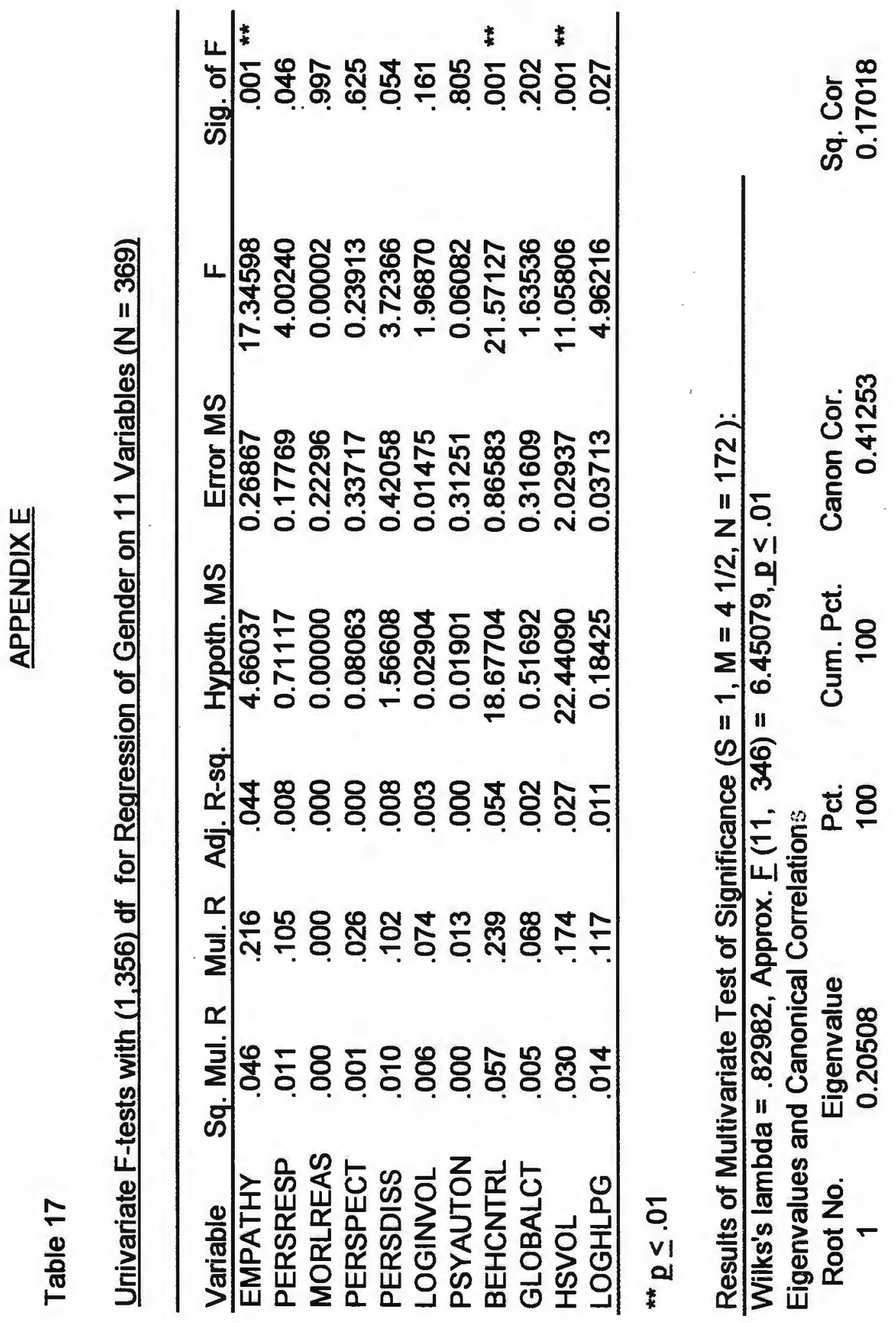




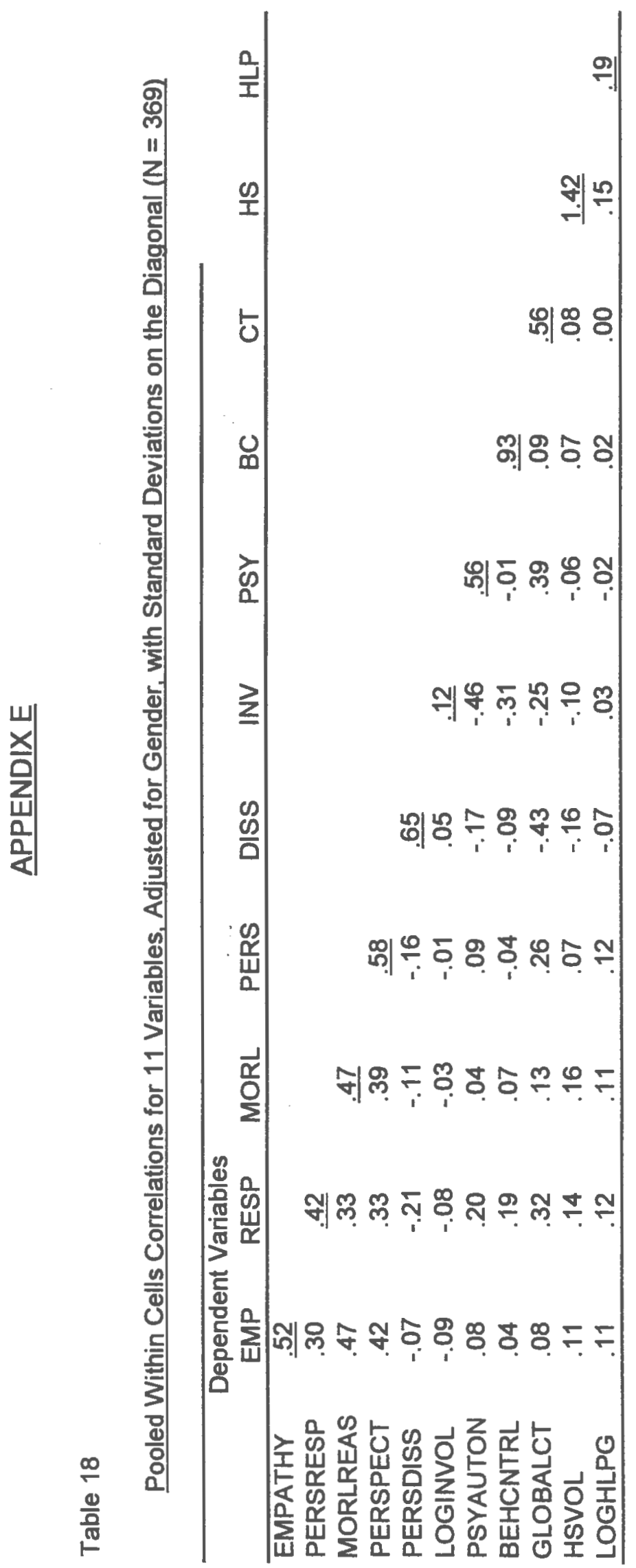


Table 19

\section{APPENDIXE}

Combined Means for 11 Variables Across 2 Levels of Volunteer Work, by Gender (141 Men, $228 \mathrm{~W}$ omen)

\begin{tabular}{|c|c|c|}
\hline Variable & $\begin{array}{r}\text { Volun } \\
\text { Nonvolun } \\
\end{array}$ & $\begin{array}{l}\text { tatus } \\
\text { olunteer }\end{array}$ \\
\hline \multicolumn{3}{|l|}{ E m pathy } \\
\hline$M$ e $n$ & 3.684 & 3.753 \\
\hline Wom en & 3.893 & 4.129 \\
\hline \multicolumn{3}{|l|}{ Persona| D istress } \\
\hline$M$ e $n$ & 2.236 & 2.062 \\
\hline Wom en & 2.341 & 2.177 \\
\hline \multicolumn{3}{|c|}{ Perspective-Taking A bility } \\
\hline$M e n$ & 3.670 & 3.755 \\
\hline Wom en & 3.752 & 3.765 \\
\hline \multicolumn{3}{|c|}{ Personal/Social Responsibility } \\
\hline$M$ e $n$ & 3.276 & 3.376 \\
\hline Wom e $n$ & 3.388 & 3.563 \\
\hline \multicolumn{3}{|l|}{ Moral Re asoning } \\
\hline$M$ e n & 3.527 & 3.794 \\
\hline Wom en & 3.633 & 3.874 \\
\hline \multicolumn{3}{|c|}{ ( Log of) Parental Involvement/Acceptance } \\
\hline$M$ e $n$ & .171 & .242 \\
\hline Wom e n & .186 & .212 \\
\hline \multicolumn{3}{|c|}{ Parents' Granting of Psychological Autonom y } \\
\hline$M$ e $n$ & 3.239 & 2.995 \\
\hline Wom e $n$ & 3.169 & 3.136 \\
\hline \multicolumn{3}{|c|}{ Parental Behavioral Control } \\
\hline$M$ e $n$ & 5.336 & 5.281 \\
\hline Wom e $n$ & 5.743 & 5.896 \\
\hline \multicolumn{3}{|l|}{ Constructive Thinking } \\
\hline$M e n$ & 3.438 & 3.454 \\
\hline Wom en & 3.391 & 3.415 \\
\hline \multicolumn{3}{|c|}{ High School Volunteer Work } \\
\hline$M$ e $n$ & 2.364 & 3.066 \\
\hline Wom en & 2.954 & 3.670 \\
\hline \multicolumn{3}{|c|}{ ( $L \circ g \circ f)$ Inform a $\mid \mathrm{He}$ elping } \\
\hline$M$ en & .126 & .224 \\
\hline Wom e $n$ & .121 & .146 \\
\hline
\end{tabular}


Table 20, Appendix E

\section{APPENDIXE}

Combined Means for for 11 Variables Across 4 Levels of University, by Gender (141 Men, 228 Women)

\begin{tabular}{|c|c|c|c|c|}
\hline \multirow{2}{*}{ Variable } & \multicolumn{4}{|c|}{ University } \\
\hline & $\# 1$ & \#2 & \#3 & \#4 \\
\hline \multicolumn{5}{|l|}{ Empathy } \\
\hline Men & 3.587 & 3.810 & 3.871 & 3.607 \\
\hline Women & 3.960 & 4.126 & 3.953 & 4.005 \\
\hline \multicolumn{5}{|l|}{ Personal Distress } \\
\hline Men & 1.992 & 2.240 & 2.239 & 2.124 \\
\hline Women & 2.256 & 2.403 & 2.328 & 2.047 \\
\hline \multicolumn{5}{|c|}{ Perspective-Taking Ability } \\
\hline Men & 3.600 & 3.779 & 3.775 & 3.697 \\
\hline Women & 3.722 & 3.896 & 3.752 & 3.663 \\
\hline \multicolumn{5}{|c|}{ Personal/Social Responsibility } \\
\hline Men & 3.416 & 3.307 & 3.404 & 3.177 \\
\hline Women & 3.489 & 3.446 & 3.408 & 3.560 \\
\hline \multicolumn{5}{|l|}{ Moral Reasoning } \\
\hline Men & 3.600 & 3.753 & 3.775 & 3.513 \\
\hline Women & 3.658 & 3.826 & 3.696 & 3.835 \\
\hline \multicolumn{5}{|c|}{ (Log of) Parental Involvem ent/Acceptance } \\
\hline Men & .214 & .211 & .233 & .166 \\
\hline Women & .214 & .181 & .217 & .183 \\
\hline \multicolumn{5}{|c|}{ Parents' Granting of Psychological Autonom y } \\
\hline Men & 3.106 & 3.109 & 3.226 & 3.028 \\
\hline Women & 3.044 & 3.309 & 3.109 & 3.146 \\
\hline \multicolumn{5}{|c|}{ Parental Behavioral Control } \\
\hline Men & 5.316 & 5.579 & 5.324 & 5.014 \\
\hline Women & 5.805 & 5.849 & 5.693 & 5.930 \\
\hline \multicolumn{5}{|c|}{ Constructive Thinking } \\
\hline Men & 3.574 & 3.444 & 3.539 & 3.228 \\
\hline Women & 3.430 & 3.324 & 3.510 & 3.348 \\
\hline \multicolumn{5}{|c|}{ High School Volunteer Work } \\
\hline Men & 2.828 & 3.063 & 2.731 & 2.238 \\
\hline Women & 3.314 & 3.217 & 3.336 & 3.382 \\
\hline \multicolumn{5}{|c|}{ (Log of) Informal Helping } \\
\hline Men & .183 & .197 & .148 & .172 \\
\hline Women & .114 & .148 & .100 & .172 \\
\hline
\end{tabular}




\section{Bibliography}

Allen, N. and Rushton, J. P. (1983). Personality characteristics of community mental health volunteers: A review. Journal of Voluntary Action Research. $12,36-49$.

Amato, P. R. (1985). An investigation into planned helping behavior. Journal of Research in Personality, 19, 232-252.

Axelrod, R. (1980). More effective choice in the prisoner's dilemma. Journal of Conflict Resolution, 24, 379-403.

Axelrod, R. and Hamilton, W. D. (1981). The evolution of cooperation. Science, 211, 1390-1396.

Asendorpf, J. B., \& Nunner-Winkler, G. (1992). Children's moral motive strength and temperamental inhibition reduce their immoral behavior in real moral conflicts. Child Development, $\underline{63}, 1223-1235$.

Bandura, A., \& McDonald, F.J. (1963). Influence of social reinforcement and the behavior of models in shaping children's moral judgments. Journal of Abnormal and Social Psychology, 67, 274-281.

Bar-Tal, D., Sharabany, R., \& Raviv, A. (1982). Cognitive basis of the development of altruistic behavior. In V.J. Derlega, \& J. Grzelak (Eds.), Cooperation and helping behavior: Theories and research. New York: Academic Press, 377-396.

Barnett, M. A., Howard, J. A., King, L. M., \& Dino, G. A. (1980). Antecedents of empathy: Retrospective accounts of early socialization. Personality and Social Psychology Bulletin, 6, 361-365.

Barnett, M. A., Howard, J. A., Melton, E. M., \& Dino, G. A. (1983). Effect of inducing sadness about self or other on helping behavior in high-and lowempathic children. Child Development, $\underline{53}, 920-923$.

Batson, C.D. (1991). The altruism question: Toward a social-psychological answer. Hillsdale, NJ: Erlbaum.

Batson, C. D., Batson, J. G., Griffitt, C. A., Barrientos, S., Brandt, J. R., Sprengelmeyer, P., \& Bayly, M. J. (1989). Negative-state relief and the empathy-altruism hypothesis. Journal of Personality and Social Psychology, 56, 922-933.

Batson, C. D., Batson, J. G., Slingsby, J. K., Harrell, K. L., Peekna, H. M., \& Todd, R. M. (1991). Empathic joy and the empathy-altruism hypothesis. Journal of Personality and Social Psychology, 61, 413-426.

Batson, C. D., Dyck, J. L., Brandt, J. R., Batson, J. G., Powell, A. L., McMaster, M. R., Griffitt, C. (1988). Five studies testing two new egotistic alternatives to the empathy-altruism hypothesis. Journal of Personality and Social Psychology, 55, 52-77. 
Batson, C. D., O'Quin, K., Fulz, J., Vanderplas, M., \& Isen, A. M. (1983). Influence of self-reported distress and empathy on egoistic versus altruistic motivation to help. Journal of Personality and Social Psychology, 45, 706718.

Baumrind, D. (1967). Childcare practices anteceding three patterns of preschool behavior. Genetic Psychology Monographs, 75, 43-88.

Baumrind, D. (1971). Current patterns of parental authority. Developmental Psychology Monographs, 4, 1-103.

Baumrind, D. (1971). Harmonious parents and their preschool children. Developmental Psychology, 4, 99-102.

Baumrind, D. (1973). The development of instrumental competence through socialization. In A. D. Pick (Ed.). Minnesota symposium on child psychology, Vol.7. Minneapolis, MN: University of Minnesota Press.

Baumrind, D. (1978). Parental discipline patterns and social competence in children. Youth and Society, 9 , 239-276.

Baumrind, D. (1989). Rearing competent children. In W. Damon (Ed.), Child Development Today and Tomorrow (pp. 349-378). San Francisco: JosseyBass.

Baumrind, D. (1991a). Parenting style and adolescent development. In R. M. Lerner, A. C. Petersen, \& J. Brooks-Gunn (Eds.), The Encyclopedia of Adolescence, Vol. 2 (pp. 746-758). New York: Garland.

Baumrind, D. (1991b). Effective parenting during the early adolescent transition. In P. A. Cowan \& M. Heatherington (Eds.), Family Transitions. Advances in Family Research (pp. 111-163). Hillsdale, NJ: Earlbaum.

Baumrind, D., \& Black, A. E. (1967). Socialization practices associated with dimensions of competence in preschool boys and giris. Child Development, 38, 291-328.

Belsky, J. (1981). Early human experience: A family perspective. Developmental Psychology, 17, 3-23.

Benson, P.L., Dehority, J., Garman, L., Hanson, E., Hochschwender, M., Lebold, C., Rohr, R., \& Sullivan, J. (1980). Intrapersonal correlates of nonspontaneous helping behavior. Journal of Social Psychology, 110, 87-95.

Berkowitz, L., \& Lutterman, K. (1968). The traditionally socially responsible personality, Public Opinion Quarterly, $\underline{32}, 169-185$.

Blasi, A. (1980). Bridging moral cognition and moral action: A critical review of the literature. Psychological Bulletin, 88, 1-45.

Block, J. H., Block, J., \& Morrison, A. (1981). Parental agreement-disagreement on child-rearing orientations and gender-related personality correlates in

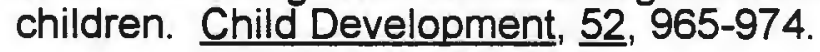


Borgida, E., Conner, C., \& Manteufel, L. (1992). Understanding living kidney donation: A behavioral decision-making perspective. In S. Spacapan \& S. Oskamp, Eds., Helping and being helped: Naturalistic studies (pp. 183-211). Newbury Park, CA: Sage Publications.

Boss, J. A. (1991). Volunteer community service work and its effect on the moral development of ethics students. Unpublished master's thesis, University of Rhode Island.

Brabeck, M. (Ed.). (1989). Who cares? Theory, research, and educational implications of the ethic of care. New York: Praeger.

Bryan, J. H. (1972). Why children help: A review. Journal of Social Issues, 28, 87-104.

Bryant, B. K. (1987). Critique of comparable questionnaire methods in use to assess empathy in children and adults. In Eisenberg, N. \& J. Strayer (Eds.), Empathy and its development. New York: Cambridge University Press, pp. 361-373.

Bryant, B. K. (1982). An index of empathy for children and adolescents. Child Development, 53, 413-425.

Burstein, E., Crandall, C; \& Kitayama, S. (1994). Some neo-Darwinian decision rules for altruism: Weighting cues for inclusive fitness as a function of the biological importance of the decision. Journal of Personality and Social Psychology, 67, 773-789.

Burton, R. V. (1963). Generality of honesty reconsidered. Psychological Review, 70, 481-499.

Carlo, G., Eisenberg, N., Troyer, D., Switzer, G., \& Speer, A. L. (1991). The altruistic personality: In what contexts is it apparant? Journal of Personality and Social Psychology, 61, 450-458.

Chapman, M., Zahn-Waxler, C., Cooperman, G., \& lannotti, R. (1987). Empathy and responsibility in the motivation of children's helping. Developmental Psychology, 23, 140-145.

Clary, E. G., \& Miller, J. (1986). Socialization and situational influences on sustained altruism. Child Development, 57, 1358-1369.

Clary, E. G., \& Snyder, M. (1991). A functional analysis of altruism and prosocial behavior: The case of volunteerism. In M. S. Clark (Ed.), Review of personality and social psychology, Vol. 12: Prosocial behavior (pp. 119 148). Newbury Park: SAGE Publications.

Colby, A. \& Damon, W. (1992). Some do care: Contemporary lives of moral commitment. New York: The Free Press.

Coles, R. (1986). The moral life of children. Boston: Houghton Mifflin.

Crowne, D. \& Marlowe, D. (1964). The approval motive. New York: Wiley. 
Curtis, M. J., \& Batsche, G. M. (1991). Meeting the needs of children and families: Opportunities and challenges for school psychology training programs. School Psychology Review, 20, 565-577.

Damon, W. (1988). The moral child: Nurturing children's natural moral arowth. New York: The Free Press.

Darley, J. M. \& Batson, C. D. (1973). "From Jerusalem to Jericho": A study of situational and dispositional variables in helping behavior. Journal of Personality and Social Psychology, 27, 100-108.

Davis, M. H. (1983). Measuring individual differences in empathy: Evidence for a multidimensional approach. Journal of Personality and Social Psychology, 44, 113-126.

Derlega, V. J. \& Grzelak, J. (Eds.) (1982). Cooperation and helping behavior: Theories and research. New York: Academic Press

Dodge, K. A. (1985). A social information processing model of social competence in children. In M. Perimutter (Ed.), Minnesota Symposium on Child Psychology: Vol. 18. Cognitive perspectives on children's social and behavioral development. Hillsdale, NJ: Erlbaum.

Dornbusch, S. M., Ritter, P. L., Leiderman, P. H., Roberts, D. F., Fraleigh, M. J. (1987). The relation of parenting stule to adolescent school performance. Child Development, 58, 1244-1257.

Dyck, J. L., Batson, C. D., Oden, A., \& Weeks, J. L. (1989, April). Another look at the altruism in the altruistic personality: Hers and his. Paper presented at the meeting of the Midwestern Sociological Association, St. Louis, MO.

Eisenberg, N. (1987). Self-attributions, social interaction, and moral development. In Kurtines, W. M. \& Gewirtz, J. L. (Eds.), Moral development through social interaction (pp. 20-40). New York: John Wiley \& Sons.

Eisenberg, N. (1988). The development of prosocial and aggressive behavior. In M.H. Bornstein \& M.E. Lamb, (Eds.), Developmental psychology: An advanced textbook (2nd edition). Hillsdale, New Jersey: Erlbaum, pp. 461495.

Eisenberg, N., Fabes, R. A., Miller, P. A., Fultz, J., Shell, R., Mathy, R. M., \& Reno, R. R. (1989). Relation of sympathy and personal distress to prosocial behavior: A multimethod study. Journal of Personality and Social Psychology, 57, 55-66.

Eisenberg, N., Fabes, R.A., Schaller, M., Miller, P., Carlo, G., Poulin, R., Shea, C., Shell, R. (1991). Personality and socialization correlates of vicarious emotional responding. Journal of Personality and Social Psychology, 61, 459-470.

Eisenberg, N., Miller, P. A., Schaller, M., Fabes, R. A., Fultz, J., Shell, R., \& Shea, C. L. (1989). The role of sympathy and altruistic personality traits in helping: A reexamination. Journal of Personality, $\underline{57}$, 41-67. 
Eisenberg, N. \& Mussen, P. H. (1977). Caring, sharing and helping: The roots of prosocial behavior in children. New York: Cambridge University Press.

Eisenberg, N. \& Mussen, P. H. (1989). The roots of prosocial behavior in children. New York: Cambridge University Press.

Eisenberg, N., Reykowski, J. \& Staub, E. (Eds.) (1989). Social and moral values: Individual and societal perspectives. NJ: Lawrence Erlbaum Associates.

Eisenberg, N. \& Strayer, J. (Eds.). (1987). Empathy and its development. New York: Cambridge University Press.

Epstein, S. (1979). The stability of behavior: I. On predicting most of the people much of the time. Journal of Personality and Social Psychology, 37, 10971126.

Epstein, S. (1980). The stability of behavior: II. Implications for psychological research. American Psychologist, 35, 790-806.

Epstein, S. (1992). Coping ability, negative self-evaluation, and overgeneralization: Experiment and theory. Journal of Personality and Social Psychology, 62, 826-836.

Epstein, S. (1993). Emotion and self-theory. In M. Lewis \& J. Haviland (Eds.), The handbook of emotions. New York: Guilford Press.

Epstein, S. \& Katz, L. (1992). Coping ability, stress, productive load, and symptoms. Journal of Personality and Social Psychology, $\underline{62}, 813-825$.

Epstein, S., \& Meier (1989). Constructive thinking: A broad coping variable with specific components. Journal of Personality and Social Psychology, 57, 332350.

Fekken, G. C., \& Holden, R. R. (1992). Response latency evidence for viewing personality traits as schema indicators. Journal of Research in Personality, 26, $103-120$.

Feshbach, N. D. (1979). Empathy training: A field study in affective education. In Feshbach, S. \& Fraczek, A. (Eds.), Aggression and behavior chance: Biological and social processes (pp. 234-249). New York: Praeger.

Feshbach, N. D., \& Feshbach, S. (1982). Empathy training and the regulation of aggression: Potentialities and limitations. Academic Psychological Bulletin, 4 399-413.

Feshbach, N. D., \& Feshbach, S. (1983). Learning to care: Classroom activities for social and affective development. Glenview, IL: Scott, Foresman.

Fitch, R.T. (1987) *. Characteristics and motivations of college students volunteering for community service. Journal of College Student Personnel, $\underline{28}, 424-431$. 
Ford, M. R., \& Lowery, C. R. (1986). Gender differences in moral reasoning: A comparison of the use of justice and care orientations. Journal of Personality and Social Psychology, 50, 777-783.

Foss, R. D. (1983). Community norms and blood donation. Journal of Applied Social Psychology, 13, 281-290.

Freedman, M. (1994). The kindness of strangers: Adult mentors, urban youth, and the new volunteerism. San Francisco: Josey-Bass.

Fritzsche, B. A., \& Penner, L. A. (August, 1992). Individual differences in decisions to offer help: "Capturing" helpers' policies. Paper presented at the 100th annual Meeting of the American Psychological Association, Washington, D.C.

Frodi, A. M., \& Lamb, M. D. (1980). Child abuser's responses to infant smiles

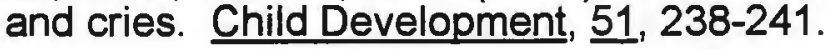

Gergen, K.J., Gergen, M.M., \& Meter, K. (1972). Individual orientations to prosocial behavior. Journal of Social Issues, 28, 105-130.

Gilligan, C. (1982). In a different voice: Psychological theory and women's development. Cambridge, MA: Harvard University Press.

Gilligan, C. \& Attanucci, J. (1988a). Two moral orientations. In Gilligan, C., Ward, J. V., Taylor, J. M., \& Baridge, B. (Eds.), Mapping the moral domain: A contribution of women's thinking to psychological theory and education (pp. 73-86). Cambridge, MA: Harvard University Press.

Gilligan, C. \& Attanucci, J. (1988b). Two moral orientations: Gender differences and similarities. Merrill-Palmer Quarterly, 34, 223-237.

Green, L. (1991). Validity studies on the family functioning scale: Family of origin version Doctoral dissertation, University of Rhode Island.

Gresham, F. M., \& Elliott, S. N. (1989). Social skills assessment technology for LD students. Learning Disability Quarterly, 12, 141-152.

Gresham, F.M. (1990). Best practices in social skills training. In A. Thomas \& J. Grimes (Eds.), Best practices in school psychology-ll (pp. 695-709).

Washington, D.C.: National Association of School Psychologists.

Grusec, J. E. (1991). Socializing concern for others in the home. Developmental Psychology, 27, 338-342.

Grusec, J. E., Kuczynski, L., Rushton, J. P., \& Simutis, Z. M. (1978). Modeling, direct instruction, and attributions: Effects on altruism. Developmental Psychology, 14, 51-57.

Gurin, P., Gurin, G., Morrison, B. M. (1978). Personal and ideological aspects of internal and external control. Social Psychology, 41, 275-296.

Hart, D. \& Fegley, S. (in press). Altruism and caring in adolescence: Relations to moral judgment and self-understanding. Child Development. 
Hartshorne, H., \& May, M. A. (1928). Studies in the nature of character. Vol. I: Studies in deceit. New York: Macmillan.

Hartshorne, H., May, M. A., \& Maller, J. B. (1929). Studies in the nature of character. Vol. Il: Studies in service and self-control. New York: Macmillan.

Hartshorne, H., May, M. A., \& Shuttleworth, F. K. (1930). Studies in the nature of character. Vol. III: Studies in the organization of character. New York: Macmillan.

Higgins, A. (1989). The just community decuational program: the development of moral role-taking as the expression of justice and care. In Brabek, M. (Ed.) (1989), Who cares? Theory, research, and educational implications of the ethic of care (pp.197-215). New York: Praeger.

Hoffman, M.L. (1975). Altruistic behavior and the parent-child relationship. Journal of Personality and Social Psychology, 31, 937-943.

Hoffman, M.L. (1979). Development of moral thought, feeling, and behavior. American Psychologist, 34, 958-966.

Hoffman, M. (1981). The development of empathy. In J. P. Rushton \& R. M. Sorrentino (Eds.), Altruism and helping behavior (pp. 44-61). Hillsdale, NJ: Erlbaum.

Hoffman, M. (1988). Moral-development. In M. H. Bornstein and M. E. Lamb, (Eds.), Developmental psychology: An advanced textbook (2nd ed., pp. 497548). Hillsdale, NJ: Erlbaum.

Hoffman, M. (1989). Empathy and prosocial activism. In N. Eisenberg, J. Reykowski, \& E. Staub (Eds.), Social and moral values: Individual and societal perspectives, (pp. 65-85). Hillsdale, NJ: Erlbaum.

James, W. (1983). The principles of psychology. (Chapter IV: Habit.) Cambridge, MA: Harvard University Press (Original work published 1890).

Kagan, J., \& Lamb, M. E., Eds. (1987). The emergence of morality in young children. Chicago: University of Chicago Press.

Kalliopuska, M. (1983). Verbal components of emotional empathy. Perceptual and Motor Skills, 56, 487-496.

Kaplan, E. A. (1989). Women, morality, and social change from a discourse analysis perspective. In Eisenberg, N., Reykowski, J. \& Staub, E. (Eds.), Social and moral values: Individual and societal perspectives (pp.347-361). NJ: Lawrence Erlbaum Associates.

Katz, L., \& Epstein, S. (1991). Constructive thinking and coping with laboratoryinduced stress. Journal of Personality and Social Psychology, 61, 789-800.

Kenrick, D. T., \& Funder, D. C. (1988). Profiting from controversy: Lessons from the person-situation debate. American Psychologist, 43, 23-34. 
Keppel, G. (1991). Design and analysis: A researcher's handbook. NJ: Prentice Hall.

Koestner, R., Franz, C., Weinberger, J. (1990). The family origins of empathic concern: A 26-year longitudinal study. Journal of Personality and Social Psychology, 58, 709-717.

Kohlberg, L. \& Ryncarz, R. A. (1990). Beyond justice reasoning: Moral development and consideration of a seventh stage. In C. N. Alexander \& E. J. Langer (Eds.), Higher stages of human development: Perspectives on adult growth (pp.191-207). New York: Oxford University Press.

Krebs, D. and Miller, D. (1985). Altruism and aggression. In E. Aronson (Ed.), Handbook of social psychology, Vol. II (3rd ed., pp. 1-72). New York: Random House.

Lamborn, S., Mounts, N., Steinberg, L., \& Dornbusch, S.M. (1991). Patterns of competence and adjustment among adolescents from authoriative, authoritarian, indulgent, and neglectful families. Child Development, $\underline{62}$, 1049-1065.

Latane, B., \& Darley, J. M. (1968). Group inhibition of bystander intervention in emergencies. Journal of Personality and Social Psychology, 10, 215-221.

Latane, B. \& Nida, S. (1981). Ten years of research on group size and helping. Psychological Bulletin, 89, 308-324.

Lerner, R.M. (1986). Concepts and theories of human development (2nd ed., pp. 265-288). New York: Random House.

Levitin, T. (1973). Values. In J. P. Robinson \& P. R. Shaver (Eds.). Measures of social psychological attitudes. Ann Arbor, Ml: Institute for Social Research.

Lynch, J. G. \& Cohen, J. L. (1978). The use of subjective utility theory as an aid to understanding variables that influence helping behavior. Journal of Personality and Social Psychology, 36, 1138-1151.

Maccoby, E. E. \& Martin, J. A. (1983). Socialization in the context of the family: Parent-child interactions. In P.H. Mussen (Series Ed.) \& E. M. Hetherington (Vol. Ed.), , Handbook of child psychology: Vol. 4. Socialization, personality, and social development (pp. 1-101). New York: Wiley.

McCord, J. (1979). Some child rearing antecedents of criminal behavior in adult men. Journal of Personality and Social Psychology, 37, 1477-1486.

Mehrabian, A. \& Epstein, N. (1972). A measure of emotional empathy, Journal of Personality, 40, 525-543.

Midlarsky, E. (1984). Competence and helping: Notes toward a model. In E. Staub, D. Bar-Tal, J. Karylowski, and J. Reykowski (Eds.), The development and maintenance of prosocial behavior: International Perspectives. New York: Plenum Press, 291-308. 
Midlarsky, E. \& Hannah, M. E. (1985). Competence, reticence, and helping by children and adolescents. Developmental Psychology, 21, 534-541.

Miller, P. A., \& Eisenberg, N. (1988). The relation of empathy to aggressive and externalizing/anti-social behavior. Psychological Bulletin, 103, 324-344.

Monroe, K.R. (1991). John Donne's people: Explaining differences between rational actors and altruists through cognitive frameworks. Journal of Politics, $\underline{53}, 394-433$.

Monroe, K. R. (1994). A fat lady in a corset: Altruism and social theory. American Journal of Political Science, 38, 861-893.

Monroe, K. R., \& Epperson, C. (1994). "But what else could I do?": Choice, identity and a cognitive-perceptual theory of ethical political behaviour. Political Psychology, 15, $210-226$.

Monroe, K.R., Barton, M.C., \& Klingemann, U. (1990). Altruism and the theory of rational action: Rescuers of Jews in Nazi Europe. Ethics 101 (October), 103122.

Noddings, N. (1989). Educating moral people. In Brabeck, M. (Ed.) (1989), Who cares? Theory, research, and educational implications of the ethic of care (pp. 216-232). New York: Praeger.

Norusis, M.J., (1990). SPSS/PC+ Advanced Statistics 4.0 for the IBM PC/XT/AT and PS/2. Chicago, IL: SPSS Inc.

Oliner, S. P., \& Oliner, P. M. (1988). The altruistic personality: Rescuers of Jews in Nazi Europe. New York: Free Press.

Penner, L. A., \& Fritzsche, B. A. (1992). Affective and cognitive correlates of individual differences in altruistic tendencies. Fifth International Nagshead Conference on Personality and Social Behavior. Boca Raton, Florida.

Penner, L.A., February, 1993. Personal communication to "People Interested in Prosocial Personality Measure". University of South Florida, Tampa, FL.

Peterson, L. (1983). Influence of age, task competence, and responsibility focus on children's altruism. Developmental Psychology, 19, 141-148.

Piaget, J. (1965). The moral judgment of the child (translated by Marjorie Gabain). New York: The Free Press.

Piliavin, J. A., \& Charng, H. W. (1990). Altruism: A review of recent theory and research. Annual Review of Sociology, 16, 27-65.

Piliavin, J. A. \& Libby D. (1985/86). Personal norms, perceived social norms, and blood donation. Humboldt Journal of Social Relations, 13, 159-194.

Power, F. C., Higgins, A., \& Kohlberg, L. (1989). Lawrence Kohlberg's approach to moral education. New York: Columbia University Press. 
Radke-Yarrow, M., \& Zahn-Waxler, C. (1984). Roots, motives, and patterns in children's prosocial behavior. In E. Staub, D. Bar-Tal, J. Karylowski, and J. Reykowski (Eds.), The development and maintenance of prosocial behavior: International Perspectives (pp. 81-100). New York: Plenum Press.

Radke-Yarrow, M., \& Zahn-Waxler, C. (1990). Research on children of affectively ill parents: Some considerations for theory and research on normal development. Development and Psychopathology, 2, 349-366.

Reimer, J. Paolitto, D. P., Hersh, R. H. (1983). Promoting Moral Growth: From Piaget to Kohlberg. New York: Longman.

Rest, J. R. (1983). Morality. In P. H. Mussen (Series Ed.), J. H. Flavell \& E. M. Markman (Vol. Eds.), , Handbook of child psychology: Vol. III. Cognitive development (pp. 556-629). New York: Wiley.

Reykowski, J. (1979). Intrinsic morivation and intrinsic inhibition of aggressive behavior. In S. Feshbach \& A. Fraczek (Eds.), Aggression and behavior change: Biological and social processes (pp. 158-182). New York: Praeger.

Rokeach, M. (1968). Beliefs, attitudes, and values (pp.156-178). San Fancisco: Jossey-Bass, Inc..

Romer, D., Gruder, C., \& Lizzadro, T. (1986). A person-situation approach to altruistic behavior. Journal of Personality and Social Psychology, 51, 10011012.

Rosenhan, D.L. (1970). The natural socialization of altruistic autonomy. In J. Macaulay \& L. Berkowitz (Eds.), Altruism and helping behavior (pp. 151-163). New York: Academic Press.

Rosenhan, D. L. (1972). Learning theory and prosocial behavior. Journal of Social Issues, 28, 151-164.

Rotter, J.B. (1966). Generalized expectancies for internal versus external control of reinforcement. Psychological Monographs: General and Applied, 80 (Whole No. 609) 1-27.

Ruble, D. N. (1988). Sex role development. In M. H. Bornstein, \& M. E. Lamb (Eds.), Developmental psychology: An advanced textbook (2nd ed., po. 411460). NJ: Lawrence Erlbaum Associates.

Rushton, J. P. (1975). Generosity in children: Immediate and long term effects of modeling, preaching, and moral judgment. Journal of Personality and Social Psychology, 31, 459-466

Rushton, J. P. (1976). Socialization and the altruistic behavior of children. Psychological Bulletin, 83, 898-913.

Rushton, J.P. (1984). The altruistic personality: Evidence from laboratory, naturalistic, and self-report perspectives. In E. Staub, D. Bar-Tal, J.

Karylowski, and J. Reykowski (Eds.), The development and maintenance of prosocial behavior: International Perspectives (pp. 271-290). New York: Plenum Press. 
Rushton, P., Brainerd, C. J., \& Pressley, M. (1983). Behavioral development and construct validity: The principal of aggregation. Psychological Bulletin, 94, 18-38.

Rushton, J. P., Chrisjohn, R. D., \& Fekken, G. C. (1981). The altruistic personality and the Self-Report Altruism Scale. Personality and Individual Differences, 2, 293-302.

Rushton, J. P. \& Littlefield, C. (1979). The effects of age, amount of modeling, and a success experience on seven- to eleven-year-old children's generosity. Journal of Moral Education, 9, 55-56.

Schaefer, E. S. (1965). Children's reports of parental behavior: An inventory. Child Development, 36, 413-424.

Schrader, D. (Ed.) (1990). New directions for child development: The legacy of Lawrence Kohlberg (whole no.47). San Francisco: Jossey-Bass.

Schwartz, S. H. (1967). Moral orientations and interpersonal conduct in moral encounters. Doctoral Dissertation, University of Michigan, Ann Arbor.

Schwartz, S. H. (1968). Words, deeds, and the perception of consequences and responsibility in action situations. Journal of Personality and Social Psychology, 10, 232-242.

Schwartz, S. H., \& Howard, J., (1981). Normative decision-making model of helping behavior. In J. P. Rushton \& R. M. Sorrentino (Eds.), Altruism and helping behavior (pp. 189-211). Hillsdale, NJ: Erlbaum,.

Schwartz, S. H., \& Howard, J., (1984). Internalized values as motivators of altruism. In E. Staub, D. Bar-Tal, J. Karylowski, \& J. Reykowski (Eds.), The development and maintenance of prosocial behavior: International Perspectives (pp. 229-255). New York: Plenum Press,.

Schwarz, J. C., Barton-Henry, M. L., \& Pruzinsky, T. (1985). Assessing childrearing behaviors: A comparison of ratings made by mother, father, child, and sibling on the CRPBI. Child Development, $\underline{56}, 462-479$.

Sibulkin, A. E. (1983). What's it to them? The value of considerateness to children. In E. L. Bridgeman (Ed.), The nature of prosocial development: Interdisciplinary theories and strategies. New York: Academic Press.

Simmons, C. H. \& Sands-Dudelczyk, K. (1983). Children helping peers: altruism and preschool environment. The Journal of Psychology, 115, 203-207.

Smithson, M., Amato, P. R., \& Pearce, P. (1983). Dimensions of helping behaviour. Oxford: Pergamon Press.

Snarey, J. R. (1985). Cross-cultural universality of social-moral development: A critical review of Kohlbergian research. Psychological Bulletin, 97, 202-232.

Snarey, J. R., Reimer, J., \& Kohlberg, L. (1985). The kibbutz as a model for moral education: A longitudinal cross-cultural study. Journal of Applied Developmental Psychology, $\underline{6}, 151-172$. 
Snyder, M. \& Omoto, A. M. (1992). Who helps and why? The psychology of AIDS volunteerism. In S. Spacapan \& S. Oskamp (Eds.), Helping and being helped: Naturalistic studies (pp. 213-239). Newbury Park, CA: Sage Publications.

Spacapan, S. \& Oskamp, S. (1992). An introduction to naturalistic studies of helping. In S. Spacapan \& S. Oskamp (Eds.), Helping and being helped: Naturalistic studies (pp. 1-15). Newbury Park, CA: Sage Publications.

Steinberg, L. (1990). Autonomy, conflict and harmony in the family relationship. in S. Feldman \& G. Elliot (Eds.), At the threshold: The developing adolescent (pp. 255-276). Cambridge, MA: Harvard University Press.

Steinberg, L., Elmen, J. D., \& Mounts, N. S. (1989). Authoritative parenting, psychosocial maturity, and academic success among adolescents. Child Development, $\underline{60}, 1424-1436$.

Steinberg, L., Lamborn, S. D., Dornbusch, S. M., \& Darling, N. (1992). Impact of parenting practices on adolescent achievement: Authoritative parenting, school involvement, and encouragement to succeed. Child Development, $\underline{63}$, 1266-1281.

Steinberg, L., Mounts, N., Lamborn, S., \& Dornbusch, S. M. (1991). Authoritative parenting and adolescent adjustment across various ecological niches. Journal of Research on Adolescence, 1, 19-36.

Stiff, J. B., Dillard, J. P., Somera, L., Kim, H., \& Sleight, C. (1988). Empathy, communication, and prosocial behavior. Communication Monographs, $\underline{55}$ 198-213.

Tabachnick, B.G. \& Fidell, L.S. (1989). Using Multivariate Statistics, Second Edition. New York: Harper \& Row.

Tourangeau, R. \& Rasinski, K. A. (1988). Cognitive processes underlying context effects in attitude measurement. Psychological Bulletin, 103, 299314.

Tureil, E. (1990). Moral judgment, action, and development. In Schrader, D. (Ed.), New directions for child development: No.47. The legacy of Lawrence Kohlberg (pp.31-49). San Francisco: Jossey-Bass, Inc.

Vaughn, B. E., Block, J. H., \& Block, J. (1988). Parental agreement and child rearing during early childhood and the psychological characteristics of adolescents. Child Development, 59, 1020-1033.

Werner, E. E., \& Smith, R. S. (1992). Overcoming the odds: High risk children from birth to adulthood. Ithica, NY: Cornell University Press.

Wilson, E. O. (1975). Sociobiology: The new synthesis. Cambridge, MA: Belknap Press.

Windmiller, M., Lambert, N., \& Turiel, E. (1980). Moral development and socialization. Boston: Allyn \& Bacon. 
Zahn-Waxler, C., \& Radke-Yarrow, M. (1982). The development of altruism: Alternative research strategies. In N. Eisenberg (Ed.), The development of prosocial behavior (pp. 109-137). San Diego, CA: Academic Press.

Zahn-Waxler, C., Radke-Yarrow, M., \& King, R. A. (1979). Childrearing and children's prosocial intentions toward victims of distress. Child Development, 50, 319-330.

Zahn-Waxler, C., Radke-Yarrow, M., Wagner, E., \& Chapman, M. (1992). Development of concern for others. Developmental Psychology, 28, 126-136.

Zarbatany, L., Hartmann, D. P., \& Gelfand, D. M. (1985). Why does children's generosity increase with age: Susceptibility to experimenter influence or altruism? Child Development, $\underline{56}, 746-756$. 